NBER WORKING PAPER SERIES

\title{
THE LABOR MARKET EFFECTS OF OPENING THE BORDER: EVIDENCE FROM SWITZERLAND
}

\author{
Andreas Beerli \\ Giovanni Peri \\ Working Paper 21319 \\ http://www.nber.org/papers/w21319 \\ NATIONAL BUREAU OF ECONOMIC RESEARCH \\ 1050 Massachusetts Avenue \\ Cambridge, MA 02138 \\ July 2015, Revised May 2018
}

We thank the following for insightful discussions and helpful suggestions that improved prior version of the paper: Andrea Ariu, Richard Blundell, Marius Brülhart, David Dorn, Christian Dustmann, Sandro Favre, Dominik Hangartner, Jennifer Hunt, Felix König, Johannes Kunz, Rafael Lalive, Guy Michaels, Tobias Müller, Jan Ruffner, Kjell Salvanes, Uta Schönberg, Michael Siegenthaler, Jan Stuhler, Jan-Egbert Sturm, Dean Yang, Josef Zweimüller, Fabrizio Zilibotti and seminar participants at the Universities of Zurich and Lausanne, at the CReAM/UCL 2015, the Milano Labor Lunch Series 2015, EALE 2016, NCCR on the move 2016, RWI/ CReAM conference 2017, the Dondena Workshop on Public Policy 2017 and the Immigration Policy Lab/ETH Zurich. We are particularly grateful to Maurizio Bigotta for sharing the data on the cross-border region identifiers. The views expressed herein are those of the authors and do not necessarily reflect the views of the National Bureau of Economic Research.

At least one co-author has disclosed a financial relationship of potential relevance for this research. Further information is available online at http://www.nber.org/papers/w21319.ack

NBER working papers are circulated for discussion and comment purposes. They have not been peer-reviewed or been subject to the review by the NBER Board of Directors that accompanies official NBER publications.

(C) 2015 by Andreas Beerli and Giovanni Peri. All rights reserved. Short sections of text, not to exceed two paragraphs, may be quoted without explicit permission provided that full credit, including $(\odot$ notice, is given to the source. 
The Labor Market Effects of Opening the Border: Evidence from Switzerland Andreas Beerli and Giovanni Peri

NBER Working Paper No. 21319

July 2015, Revised May 2018

JEL No. J2,J24,J61

\begin{abstract}
$\underline{\text { ABSTRACT }}$
Between 1999 and 2004 Switzerland opened its border region (BR) to cross-border workers (CBW), who are foreign residents commuting to Switzerland for work. In this paper, we exploit the timing of implementation and the fact that $\mathrm{CBW}$ commute almost exclusively to municipalities close to the border to estimate the effect of this policy on foreign labor supply and on native labor market outcomes, using a difference-in-difference approach. We find that opening the border to $\mathrm{CBW}$ increased their employment within 20 minutes of commuting time from the border by four to five percentage points. The increased inflow was constituted of highly-educated workers and it was associated with an increase in wages for highly-educated Swiss workers. Native highly-educated workers became more likely to fill top managerial positions after the liberalization. Moreover, we find increases in wages, employment and firm-creation, especially in high-skilled manufacturing and knowledge-intensive services, which help explain the positive wage effects of CBW on high skilled natives.
\end{abstract}

\author{
Andreas Beerli \\ ETH Zurich \\ KOF Swiss Economic Institute \\ LEE G 116 \\ Leonhardstrasse 21 \\ 8092 Zürich \\ Switzerland \\ beerli@kof.ethz.ch \\ Giovanni Peri \\ Department of Economics \\ University of California, Davis \\ One Shields Avenue \\ Davis, CA 95616 \\ and NBER \\ gperi@ucdavis.edu
}

A online appendix is available at http://www.nber.org/data-appendix/w21319 


\section{Introduction}

Some politicians in European countries are reconsidering their commitment to the free mobility of workers within the European Union (EU), saying that immigration from the rest of Europe has harmed the labor market opportunities of their native workers. ${ }^{1}$ Free mobility of workers, however, means more opportunities for businesses to hire a wider variety of skills. This may stimulate productivity and growth, offsetting the consequences of labor market competition so that employment and wage effects for natives need not be negative.

Rarely have economists been able to study the consequences of a policy that permanently and completely opened labor market access to foreign workers. This is what we do in this paper. We consider the case of Switzerland, which-progressively, between 1999 and 2007-granted EU citizens free access to its labor markets. In particular, we focus on a group of foreign workers who were granted free access first. These "cross-border workers" (CBW) of Switzerland are residents of the bordering countries (Italy, Germany, Austria and France) and are allowed to work in Switzerland, commuting from their countries of residence. Agreements regulating the flow of CBW date back to the first part of the 20th century, when Swiss employers could hire them if no Swiss resident was found to fill a job opening. Beginning in 1999, with the signing of the bilateral agreement for free labor mobility with the EU, the constraints on Swiss employers to hire CBW were progressively reduced. In the border regions limitations to hire CBW were fully abolished in 2004; in 2007 the other categories of EU immigrants were granted full labor market access in Switzerland. Despite mounting discontent, full access of CBW to Swiss labor markets has persisted to this day. ${ }^{2}$

The policy events affecting CBW in Switzerland are useful as a case-study of a policy that permanently and fully removed legal barriers to labor market access for foreign labor. There are important advantages and some caveats in studying this CBW liberalization with an eye to the identification of its labor market impact. First, the liberalization policy had a clear pre-event period. Before 1999 it was not even clear that Switzerland would have pursued free mobility with the EU. During this period there were several restrictions on CBW. It also had a clear post-implementation period, beginning in 2004, when full liberalization of CBW (in Border regions) was allowed. 1999-2004 was a transitional period in which a gradual but still limited liberalization took place, and expectations of complete liberalization developed.

\footnotetext{
${ }^{1}$ Following these type of fears, British citizens voted, on June 23rd 2016, to leave the EU (the so-called "Brexit")

${ }^{2}$ The Ticino region of Switzerland voted a measure in September 2016, to limit again the movement of CBW. That measure will not become law if it is not approved by the federal government. See "The Parable of Ticino" in The Economist (2016), September 24th.
} 
Second, as CBW commute to work from abroad-and most of them commute daily-the policy generated increased availability of CBW prevalently in regions very close to the border. Employment of CBW sharply drops with distance from the border, as we will show. In locations beyond 30 minutes of driving distance from the border, their numbers were and remained negligible throughout the considered period. This creates a natural framework for a differencein-difference analysis: If we compare labor markets very close to the border (treatment group) with those farther away but similar (control group) before and after the liberalization policy, we can identify a causal effect of the policy provided that the control group is a reasonable "counterfactual" for the "treated municipalities".

Third, while one could be concerned with the external validity of the estimated effects, two features make it especially interesting. As with other immigrants, because CBW are employed in Switzerland they constitute additional labor supply, but because they live abroad they likely generate smaller local consumption/demand effects compared to other immigrants. As they spend a large portion of their incomes in their countries of residence, several demand-side effects-for example, on local housing prices (e.g. Saiz, 2003) and on local demand for non-tradable consumption goods (e.g. Hong and McLaren, 2015)-are almost certainly weaker. Hence the starkest effects of this policy should be on labor demand for native workers. Moreover, this policy change was perceived as producing a permanent increase in the share of foreign-born workers in areas close to the border. This is in contrast to the temporary push-driven surges in immigrants (such as the Mariel Boatlift in Miami or the outflows from Russia to Israel at the end of the cold war), and can provide particular insight into the long-run effects of permanently changing immigration policies.

The main findings of this paper are the following: First, the full liberalization of CBW in Switzerland (starting in 2004) produced an increase of cross-border workers equal to between four and five percentage points of total employment in municipalities within a 10 minute commute from the border (treated group) relative to those farther than a 30 minute commute from the border (control). Municipalities within 10 to 20 minutes of commuting time (treated but not as intensely) experienced an increase of about 2 to 3 percentage points of the labor force, while municipalities between 20 and 30 minutes of commuting time from the border experienced less than a one percentage point change. There is mild, not statistically significant evidence of an increase in CBW during the transitional 1999-2004 period; the increase became larger and statistically significant only after the full liberalization of 2004. We also document that the inflow of CBW was strongly concentrated among highly- and middle-educated workers. Low-educated 
CBW showed no increase, and possibly a decline after 1999.

Second, looking at the impact on wages and employment of native workers, we find that native Swiss workers with tertiary education within 10 minutes from the border experienced a (statistically) significant positive wage change after full liberalization in 2004. Primary-educated workers experienced a less significant increase in employment and total hours worked, instead. The changes of wages and hours worked by secondary-educated workers in the 10- minute commuting area were not significant. As the change in CBW represented an inflow of highly-educated workers, the wage increase of highly-educated natives cannot be rationalized by a simple model of a pure supply shift with high and low skilled labor and no demand changes (such as Goldin and Katz (2008) or Borjas (2003)). Hence we document several channels that show adjustment in native occupations, and increases in productivity and firm creation, which may rationalize these effects.

One important adjustment channel is that highly-educated native workers responded to the increase of CBW by taking new managerial positions and climbing the managerial ladder. Another sign of a positive productivity/investment effects is that we find strong positive wage and employment changes in high tech manufacturing and human capital intensive sectors, which employ most high skilled workers. We also find some evidence of stronger firm creation closer to the border. This implies capital investment and sectoral reallocation that is consistent with the complementarity of highly-educated CBW with capital and highly-educated native workers.

While rigorous analysis of the short- and long-run effects of important immigration policy changes are rare, two recent papers exploit changes in policies on cross-border workers to learn about the effects of foreign labor supply and are closely related to this paper. Dustmann, Schönberg and Stuhler (2017) analyzes the opening of Germany's border to Czech cross-border workers in June 1991. Between 1991 and 1993, employment of Czech workers increased strongly in areas close to the border. The paper tracks the effect on employment and wages of natives. After 1993, the policy was de-facto withdrawn and a corresponding decrease in the number of Czech workers took place. The paper analyzes the short-run impact of such temporary shocks in a difference-in-difference set-up. It finds a strong, negative effect on employment of natives and a more moderate, negative effect on wages. The negative effect on native employment is mainly due to smaller inflows of natives from other regions of Germany. The authors use distance from the Czech-German border as a determinant of the intensity of the supply shock (treatment) and compare native outcomes in treated and matched regions farther from the border. Importantly, the episode they study was temporary, as the policy was only in place 
for two years, and cross-border workers were mainly low-skilled. It took place in a historically extraordinary period, when the economy of the Czech Republic was depressed and undergoing a major transition, right after the fall of the Communist regime. Several features of the Swiss context and policy stand in contrast to the German one. Its early announcement, its phased-in implementation and predictability, and the fact that immigrants were mostly high-skilled, plus the longer-run perspective of the policy and of our analysis, make this case more similar to standard change in immigration policies. These factors may also help explain the more positive wage and employment effects for native workers that we find relative to Dustmann, Schönberg and Stuhler (2017).

In another paper, most closely related to ours and written concurrently, Ruffner and Siegenthaler (2016) present complementary results on the impact of the same liberalization episode in Switzerland on firms' outcomes. Using a difference-in-difference identification strategy similar to ours, they show that the policy had a positive impact on the R\&D and innovation activity of firms, and that positive productivity effects were concentrated in firms that used CBW more intensively. We discuss their results in greater detail below, as well as how they compare to and complement ours. The focus of our paper is to document the validity of the policy experiment, and to characterize the dynamics and the channels through which immigration affected wages, employment, and regional- and occupational-mobility of natives. In particular, we consider the internal migration dynamics and the sector- and skill-specific responses of Swiss workers to the opening of the border. In contrast, Ruffner and Siegenthaler (2016) use a firm-level database to analyze the impact of the policy on domestic firms' outcomes, showing important evidence of effects on productivity, R\&D and patented innovation. ${ }^{3}$

Evaluating the impact of specific policy changes is a step forward in the literature on the labor market effects of immigrants. Most studies perform panel regression analysis exploiting area variation of immigrants. Often, however, these studies lack a strong identification strategy, so the results can only be interpreted as partial correlations. Some of the most prominent papers in the literature are summarized in Blau and Kahn (2012), Lewis and Peri (2014), and Longhi, Nijkamp and Poot (2005). Apart from these, only a few recent papers have analyzed specific immigration policy changes and their impact on economic outcomes. Kerr and Lincoln (2010) and Peri, Shih and Sparber (2015a) have exploited the change in the H1-B visa cap (the

\footnotetext{
${ }^{3}$ Two policy reports (Henneberger and Ziegler, 2011; Losa, Bigotta and Gonzales, 2012) were the first to study the effects of CBW liberalization by comparing wage and employment changes between regions close to the Swiss border and central regions. In an unpublished paper, Bigotta (2013) analyzes the effects of this policy on the unemployment duration of natives. We will discuss these papers too, but their methodology is quite different so that their findings are harder to compare with ours.
} 
high-skilled immigrant visas in the U.S.) to analyze effects on innovation and productivity in U.S. cities. Bohn, Lofstrom and Raphael (2014) analyzed the impact of Arizona's Worker Act on undocumented immigrant labor market performance. For Europe, Glitz (2012) analyzed the effect of a policy allowing ethnic Germans in Eastern Europe to obtain German citizenship, which generated-in combination with the fall of the iron curtain-a sudden inflow of migrants. Also combining a sudden push-driven inflow of refugees and national policies of refugee dispersal, Foged and Peri (2016) estimate the impact on natives' wages, employment, and occupational transitions. They find substantial job upgrading among natives that granted them positive wage effects after the refugee inflow. A handful of additional papers tried to measure immigration policies and estimate the effect of policy changes on immigrant inflows in a multi-country gravity framework. Mayda (2010) and Ortega and Peri (2014) are two examples. In the Swiss context, Abberger et al. (2015) show that freer immigration for EU workers increased their net inflows by 10,000 to 15,000 individuals annually. Beerli, Indergand and Kunz (2017) show that the increase in the positive selection of newly-arriving immigrants is mostly driven by long-run shifts in the demand for skills triggered by skill-biased technology, rather than by immigration policies. Our paper is new in that it identifies the effect of a major and permanent policy change, and evaluates its consequences on the number and type of immigrant flows and the ensuing effects on local labor markets.

The rest of the paper is organized as follows. Section 2 describes the changes in policy concerning the access of cross-border workers to jobs in Switzerland between 1999 and 2010. Section 3.1 and 3.2 describe the main data sources and the key trends relative to the supply of cross-border workers and resident immigrant workers, and shows summary statistics of demographics and labor market outcomes of citizens. Section 3.3 discusses the main empirical specifications and section 4 presents the estimates of the impact of border liberalization on the supply of CBW. Section 5 analyzes the consequences on key labor market outcomes for natives such as wages, employment, and hours worked. Section 6 inquires into possible channels, dynamic transitions, and heterogeneous effects triggered by opening the border to CBW. We also compare our empirical results with those existing in the literature. Section 7 concludes.

\section{Policy Framework and Timeline}

The process of opening the Swiss labor market to European Union citizens started with the signing of the bilateral agreements between the EU and Switzerland on June 21, 1999. Before 1999 there was not even a clear expectation about the possibility of free mobility between Switzer- 
land and Europe. The main piece of this bilateral Agreement focused on the Free Movement of Persons (AFMP), i.e. full bilateral access to each other's labor markets. In an announcement by the federal administration in 1999, it became clear that cross-border workers would be the first group to benefit from a phase-in of the liberalization reform (Bundesrat, 1999). Yet the exact implementation of the liberalization remained uncertain since the bilateral agreements had to go through a ratification process in all EU member states and through a national referendum in Switzerland. This took place in May 2000, and the agreement was approved with $67.2 \%$ of votes. On June 1, 2002, the AFMP was enacted, 1.5 years after the target date that was initially announced.

The AFMP was part of larger bilateral package of agreements aimed at reducing the "institutional and economic isolation" of Switzerland that may have resulted from the rejection of the European Economic Area membership in 1992 in a national referendum. ${ }^{4}$ At the beginning of the negotiations in 1993 that led to these agreements, the Swiss government tried to avoid a full-fledged version of free worker mobility. This position was rooted in the concern that neither the Swiss border cantons nor the population as a whole would accept a broad mandate since they rejected joining the EEA largely due to fears of immigration from the rest of Europe. As the EU insisted on full free mobility, a breakthrough in the negotiations was only reached when both parties agreed that the full free mobility would be implemented step-wise and included further safety measures that the Swiss could trigger unilaterally, if necessary (Bundesrat, 1999). ${ }^{5}$ These political circumstances and the fact that the federal government, and not Cantons, negotiated the AFMP agreements, imply that the local economic conditions of border municipalities were not a consideration in the timing and content of the agreements.

The group of cross-border workers (CBW) enjoyed a special status in the border region (BR). ${ }^{6}$ Prior to 1999 , firms were allowed to hire CBW if no equally qualified resident worker could be found for a given job (the so-called "priority requirement"). ${ }^{7}$ Moreover, CBW could

\footnotetext{
${ }^{4}$ The package of bilateral agreements also included agreements on the reduction of technical barriers to trade, the liberalization of trade in agricultural goods, public procurement, and transport, and the participation of Switzerland in the EU's research framework program. See the Online Appendix C for more details on the bilateral agreement.

${ }^{5}$ The two safety measures that the Swiss could trigger were the following. First, the "safeguard clause" allowed Switzerland to reinstate quotas on immigration temporarily, if the inflow of workers exceeded a certain threshold. Second, Switzerland could re-evaluate its bilateral agreements with the EU 7 years after implementation with a national referendum. Fears of labor market competition were voiced after the AFMP was signed. This is an example from a prominent newspaper at the time (Neue Zürcher Zeitung, 1999, Sept. 2): “The high prevailing wage level in Switzerland raises fears of wage dumping. These concerns are particularly pronounced in the border region where the free movement of persons is expected to raise the competition in the labor market."

${ }^{6}$ Bilateral agreements on CBW were signed with Italy in 1928, with France in 1946, with Germany in 1970 and with Austria in 1973.

${ }^{7}$ Firms had to provide the cantonal migration offices with details about the job requirement and the working conditions before hiring CBW. They also had to demonstrate to have searched unsuccessfully for a suitable Swiss worker. In turn, the cantonal immigration offices checked whether there was no equally qualified resident worker
} 
not work in the non-border region (NBR) of Switzerland. The remaining foreign workers who resided in Switzerland, which we simply call immigrants (I), were subject to yearly national quotas set by the federal government and to the "priority requirement". Immigrants could work anywhere in Switzerland. Figure 1 shows a map of Switzerland with the municipalities in the BR shaded in gray, while the NBR are represented in white. The separation of municipalities between BR and NBR does not overlap with the cantonal borders (indicated by black lines) nor with other cultural characteristics of the population (e.g. the major language areas). The boundaries of the BR remained unchanged with the introduction of the free movement policy, and we use the BR definition as it was during the period 2000-2010. ${ }^{8}$

Between 1994 and 1999, the status quo was as described above. This is what we call the Pre-Liberalization Phase: CBW had restricted access to the labor market in the BR, they had to commute daily, and they could not work in the NBR. Then between June 1, 1999 and May 31, 2004, during the transitional phase, cantonal immigration offices in the border region gained more discretion in allowing firms to hire $\mathrm{CBW} .{ }^{9}$ In particular, the official introduction of the AFMP in 2002 was an important step toward opening the border region labor market to CBW. Their permits were no longer bound to a particular job and remained valid for five years (rather than only one year), and applicants for CBW permits were not required to have resided in the adjacent border region of the neighboring country for the previous six months. In addition, CBW were allowed to commute weekly (rather than daily) and adopt a secondary residency in Switzerland. It appears, however, that only a small fraction of CBW switched to weekly commuting during our period of analysis. ${ }^{10}$ As argued above, the fact that CBW work but do not reside in Switzerland suggests a more muted impact of CBW on local consumption (housing, etc.) compared to resident immigrant.

On June 1, 2004 the full liberalization phase (or Free movement phase) of the reform was enacted and the labor market of BR municipalities became fully accessible to CBW who could be hired by local firms under no different conditions than Swiss workers. CBW still had no

\footnotetext{
registered as unemployed. This procedure imposed substantial costs for firms to hire CBW.

${ }^{8}$ Notice that the area within 25-30 kilometers form the Swiss border is almost exclusively occupied by the BR

${ }^{9}$ Conversations with representatives from cantonal immigration offices revealed there was also a more relaxed handling of new CBW applications after 1999, and particularly after the national referendum on May 21, 2000, as it was clear that eventually CBW would be the first to gain unrestricted access to the border region.

${ }^{10}$ Two pieces of evidence corroborate this conjecture. First, we collected data about the secondary residence status of CBW among top 60 municipalities where most CBW were employed in 2010 according to the Swiss crossborder registry. In a sample of 20 top destinations for CBW, for which we were able to collect data (registration of this status is not mandatory for municipalities), less than $2 \%$ of all CBW were registered as weekly commuters by 2010. Second, in the sample of all CBW from Germany available in the Swiss cross-border worker register (1996-2010) for which we were able to geo-code their (primary) place of residence abroad, 99\% live in two adjacent states Baden-Württemberg or Bayern, of which $89 \%$ and $99 \%$ live within 30 and 60 minutes driving time from the Swiss border, respectively.
} 
access to work in the NBR but, as we will see, given their commuting patterns, employers in NBR hired almost no CBW before or after full liberalization. This phase marks the biggest change in freedom of access to labor markets for cross-border workers. Only on June 1, 2007 did Non-Border regions adopt full liberalization for CBW and for immigrants from the EU.

The progressively easier access of CBW to labor markets in the border region from 1999 to 2004 generated a growing asymmetry in access to foreign labor supply between municipalities close to the border and those farther away. CBW, whose concentration was largest within the areas closest to the border, had progressively more access to Swiss jobs after 1999 and mainly after 2004. Other EU immigrants to Switzerland had the same access to all labor markets in Switzerland, if they were admitted. It is this spatial difference and the timing of the reform that we use in our identification strategy. Finally let us emphasize that the bilateral agreement with EU countries allowed Swiss people to commute across the border, too. However, their employment in the border regions of Italy, France, and Germany did not change in a significant way (see Ruffner and Siegenthaler, 2016) because the wage differential was strongly in favor of the Swiss side of the border.

\section{Data, Summary Statistics and Empirical Strategy}

\subsection{Data Sources and Variable Definitions}

The main source of our data is the Swiss Earnings Structure Survey (SESS) which collected demographic and labor market information every two years from 1994 to 2010. The survey constitutes a repeated cross-section representative of all individuals working in Switzerland. ${ }^{11}$ It includes detailed information about workers, their demographic characteristics, and their place of work identified to the zip code level. We use this information to identify the municipalities where individuals work. Municipalities are the smaller units identified in Figure $1 .{ }^{12}$ As described in Section 2 and shown in the Figure, each municipality belongs either to the BR or the NBR. To compute the shortest travel time to the national border for each municipality, we identified municipalities with a road border crossing using data from Federal Customs Administration, and used data on road travel time between any two municipalities from search.ch, a web search

\footnotetext{
${ }^{11}$ The official title of this data set is "Bundesamt für Statistik, Schweizerische Lohnstrukturerhebung 1994-2010" (BFS, 2010). The survey collects information on labor market variables on October 31 of each year.

${ }^{12}$ We use an official crosswalk from the Federal Statistical Office (FSO) between Municipalities and zip Codes. As the number of municipalities (and zip codes) changed over time due to mergers, we use the municipality definition in year 2000 as a time-invariant unit. Observations with outdated zip codes that could not be linked (less than $0.3 \%$ ) were dropped. We thank Maurizio Bigotta for sharing the data of border region identifiers for each Swiss municipality. See Losa, Bigotta and Gonzales (2012) for a detailed description.
} 
engine. $^{13}$

The sample we use includes individuals between 18 and 65 years of age, working in the private sector, with non-missing information for nationality, place of work, education, wages, hours worked, and other basic demographics. In the data we distinguish three types of workers based on their residency permit. The first are native workers-those with Swiss nationality either born in Switzerland or naturalized; the second are foreign-born workers with a residency permit which we call simply immigrants (I); and finally we have cross-border workers (CBW). Combined, we denote the last two groups as foreign-born. ${ }^{14}$

The first and most direct outcome of the policy we analyze is the net change in the number of cross-border and foreign-born workers as a share of total employment. When we consider outcomes relative to native workers in a municipality, we use the total number of hours worked and their hourly wage as measures of their labor supply and marginal productivity, respectively. The data set contains the gross monthly wage for each individual worker (in the month of October) in Swiss Francs. This measure includes social transfers, bonuses, and one-twelfth of additional yearly payments. We divide this measure by the number of hours worked in October, and use the consumer price index to deflate it into the real hourly wage of an individual worker at 2010 constant prices. We express hours worked as a fraction of the number of hours worked by a full-time worker, so that one unit is a full time equivalent (FTE).

In our analysis, we aggregate data at the municipal level, constructing the total number of workers, the total hours worked, the average log hourly wage and other variables at that geographical unit. ${ }^{15}$ In most of the analysis we separate outcomes by schooling group. Education is a key determinant of skills and productivity and hence we identify three groups, by level of schooling, which we occasionally simply call skill groups. This three-group partition augments the common one between college- and non-college-educated used in large part of the wage inequality and immigration literature (e.g. Katz and Murphy, 1992 or Autor, Katz and Kearney, 2008), especially in the US. The intermediate level of schooling is included to capture the fact that in the Swiss education system people with secondary education tend to have technical and vocational degrees, and not a high school diploma. They work in specialized jobs and are likely to constitute a group of abilities which is rather differentiated from those

\footnotetext{
${ }^{13}$ We thank search.ch and Andreas Steinhauer for sharing the commuting data with us. Municipalities with a border crossing are assumed to have zero travel time to the national border.

${ }^{14}$ The group we call immigrants hold either an L permit (4 to 12 months) or a B permit (1 to 6 years). Crossborder workers hold a $\mathrm{G}$ permit. The foreign-born individuals with a permanent residence permit (C permit) can be considered as long-time immigrants. This is a group that we do not include in our analysis as its status was not affected by any changes in policy.

${ }^{15}$ When analyzing wage outcomes we trim our sample by excluding individuals with wages above the 99th percentile of real hourly wages in each year.
} 
of workers with primary education only. We define workers with tertiary education as being highly-educated. Workers with less than a college education with a secondary school diploma are defined as middle-educated and workers with only primary education, completed or not, are called low-educated. ${ }^{16}$

In section 6 , we augment our data with two additional data sets in order to analyze worker transitions across municipalities and employment status and heterogeneous effects in different subgroups. The first data set is the Swiss Labor Force Survey (SLFS), which we use with similar sample restrictions and definitions for skill groups and geography. This data set covers the whole population, including unemployed and individuals currently not in the labor force. Information on the place of work of individuals is available yearly since 1996. As individuals were interviewed repeatedly (up to five years), we can track individuals over consecutive years and analyze their mobility in terms of location, as we do in section $6 .{ }^{17}$ A second additional data set we use is the Swiss Business Census (BC), available in 1991, 1995, 1998, 2001, 2005 and 2008. This database covers the universe of public and private sector establishments in Switzerland, and reports for each the total employment of natives and foreign workers. This is the database mainly used by Ruffner and Sieghentaler (2017) in their firm-level analysis. We use it only to analyze the share of native workers across different industries and the birth of new establishments in sections 6.3 and 6.4 .

\subsection{Summary Statistics and Key Trends}

The number of CBW employed in the Border Region of Switzerland increased from $7 \%$ to $9.5 \%$ of total employment between 1998 and 2010. Importantly, this non-negligible increase was very unevenly distributed within the Border Region. The Border Region includes Swiss municipalities both between 0 and 30 minutes from and those more than 30 minutes travel time from the border. Cross Border Workers, as we will detail below, were almost exclusively employed, before and after the reforms, in municipalities between 0 and 30 minutes from the border. We first describe how the characteristics of CBW compare to the characteristics of native workers. The potential labor market impact of their inflow depends on their number and on their skills. Table 1 shows

\footnotetext{
${ }^{16}$ The education variable has some missing information (roughly $15 \%$ on average). As a consistency check of all results, we alternatively classified workers into three wage tercile groups, each year, and also try splitting them into three groups using the the 24 available occupations in the SESS data to classify them into groups of high, middle and low-paying occupations. All results that we show are similar when we use these alternative occupation or wage-based skill classifications. See Appendix, Figure A3 (effect on wages) and Figure A4 (effect on hours).

${ }^{17}$ We focus on individuals' transitions between two consecutive years as most individuals are only two consecutive years in the panel. Although this data set is much richer in scope than the SESS, its sample is significantly smaller, which implies significantly larger measurement error at the level of the municipality. All our baseline findings based on the SESS are qualitatively similar when we use the SLFS instead.
} 
the summary statistics for the population of CBW and native workers in the border regions of Switzerland. We report the characteristics of those two populations in 1998 and 2010 and, more importantly, their change, which provides information on the net inflow of CBW relative to natives. Four features are noteworthy. First, while in 1998 the composition of CBW was more concentrated among the less-educated relative to natives (with 33\% among CBW with only primary education versus $13 \%$ of natives), the change in composition of CBW during the considered period was strongly toward highly-educated. The net change 1998-2010 for CBW implied a large increase in the share of highly educated $(+12.6 \%)$ and a corresponding decline in the share of less educated $(-10 \%$, see the columns labeled "change" in Table 1$)$. Second, the net inflow of CBW was concentrated in middle and low management positions, but not in high management positions that remained predominantly occupied by natives. This is consistent with the interpretation that CBW were highly-educated and had technical skills, but possibly lacked the cultural skills to be at the very top management levels of Swiss companies. Third, their inflow between 1998 and 2010 was mainly in the intermediate and high tercile of the wage distribution, confirming their high level of skills. Finally, the sector composition of new CBW was strongly concentrated in IT/R\&D/Business/real estate and, to a lesser extent, in the Health sector. CBW were, in large part, professionals in science and technology.

Our identification strategy will be based on the timing of the labor market liberalization for $\mathrm{CBW}$ and on the difference that the policy change produced in municipalities close to the border relative to those further away. Figure 2 shows the change in CBW which will provide the key identifying variation in our analysis. In the top two panels of that figure, denoted as Panel A, we show CBW as share of total employment in municipalities grouped and arrayed from left to right by commuting time from the national border. The graph shows the values aggregating 5 -minute bins from 0 to 85 minutes of travel time from the border, with 0 representing a municipality with a border crossing. Each of the two top panels has four lines, representing the CBW share of employment in different years. We show the connected values for the years 1994 and 1998, which are before any policy change, for year 2004 which is at the end of the Transition Phase and at the very beginning of Full Liberalization, and then in year 2010, which is six years after full liberalization. ${ }^{18}$ period. The left panel represents municipalities in the Border Region going up all the way to the national border. The panel on the right represents municipalities in the Non-Border region (NBR) and, hence, it does not include municipalities less than 35 minutes

\footnotetext{
${ }^{18}$ In fact, the full free mobility of CBW was implemented on June 1, 2004, and the data points in the SESS represent the situation of the labor market in October 31 of a particular year. Thus, the data point in 2004 can be regarded as the first year of the Full Liberalization
} 
from the border. That panel also shows that there was a negligible number of CBW in the NBR both before the reforms as well as in the transition and full liberalization phases. ${ }^{19}$ It is clear from these two pictures that CBW were a significant share of employment only in border regions and, within them, only in municipalities very close to the border. Even before the policy reform, CBW constituted 10-20\% of employment, but only in municipalities within 10-15 minutes of commuting time from the border. The gradient of their employment share is very steep so that past 30 minutes of commuting time from the border their presence, both in the BR and in the NBR, was essentially zero.

The two lower panels of Figure 2 show the smoothed net change in CBW as share of employment in 1998 for the period 1994-1998 (pre-liberalization), for the period 1998-2004 (during the Transition phase), and for the period 2004-2010 (during Full Liberalization phase). ${ }^{20}$ We notice that the 1994-1998 change is extremely small and even negative for municipalities near the border. The change in the period 1999-2004 is positive for municipalities between 0 and 20 minutes from the border and negligible elsewhere, and the change between 2004 and 2010 is large and positive for municipalities up to 20 minutes from the border, non-negligible but much smaller for municipalities between 20 and 30 minutes from the border, and negligible for municipalities with a commute to the border above 30 minutes (and exactly zero above $35-40$ minutes). Hence it appears that most of the change associated with liberalization of CBW took place between 0 and 20 minutes from the border, with some effects up to 30 minutes. The border-region over 30 minutes from the border and the non-border region (represented on the right in Panel B of Figure 2) shows essentially no changes during the Transition or the Full Liberalization phases: CBW did not work there even after liberalization. The focus of our analysis, therefore, is on the BR. We consider the municipalities in the $0-10$ and $10-20$ minute bins as, respectively, most strongly treated and strongly treated. Those between 20 and 30 minutes are weakly treated. The municipalities over 30 minutes are the control group. In some robustness checks we also include municipalities in the non-border region in the control group. We additionally check that the large inflow of CBW in municipalities near the border between 2004 and 2010 was not offset by a corresponding decrease of immigrants but, rather, that it resulted in a total increase of foreign-born workers in those regions. This is shown in the Appendix. In Panel B of Appendix Figure A1, we can see that, for the border regions, the change in foreign-born as a share of

\footnotetext{
${ }^{19}$ For the sake of illustration, bins with a very low level of total employment are omitted from this figure, i.e. bins in the border region more than 80 minutes from the border, and bins in the non-border between 13 and 35 minutes and above 85 minutes from the border. In the analysis below, the sample includes all municipalities as indicated.

${ }^{20}$ To reduce noise, we smoothed the change in CBW as a share of total employment in 1998 using a local polynomial with bandwidth 10 minutes.
} 
employment mirrors the changes of CBW being zero to negative and was rather flat in the 19941998 period, positive and decreasing with distance in the 1999-2003 period, and larger and with a steeper decline away from the border in the 2004-2010 period.

It is also useful to compare the economic and demographic characteristics across the three regions $(0-10,10-20$ and $20-30)$ that received different intensity of "treatment" (availability of $\mathrm{CBW}$ ), and with the regions above 30 minutes of commuting time from the border, both in the BR and in the NBR. Table A1 in the Appendix shows summary statistics for municipalities in the border region in the distance bins at $0-10,10-20,20-30$, and more than 30 minutes travel time from the Swiss border. The last columns shows the characteristics of municipalities in the entire non-border region that we add to the control group in some specifications. Looking at education, age, and gender composition as of 1998, the last year before the policy changes, one does not identify any specific or systematic differences. In our empirical analysis we control for fixed effects at the municipality levels, region-trends, and sector-composition driven effects. However, there does not seem to be a systematic correlation of the considered economic variables with the distance from the border, which provides further reassurance to the validity of our identifying assumption. As we will detail below, we also test the pre-1999 trend in immigrants and cross-border workers across distance bins to make sure that those were not significantly different.

\subsection{Basic Treatment-Control Specification}

Our basic empirical specifications test whether, during the Transition (1999-2003) and/or during the Full Liberalization (2004-2010) phases, labor market outcomes in municipalities close to the border (and hence treated), changed differentially from those in municipalities farther than 30 minutes from the border (and hence non treated), vis-à-vis their relative behavior pre-1999. To

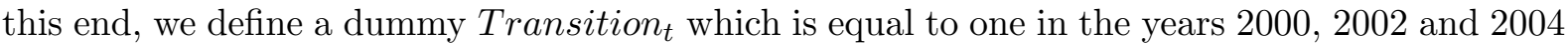

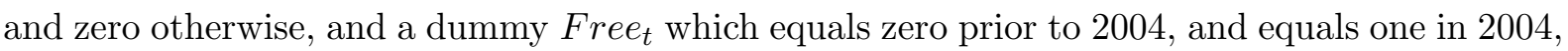
2006, 2008 and 2010. Then we interact these two variables, which denote the two different phases of the reform in the Border Regions, with indicator dummies that differentiate municipalities according to their travel-time distance from the border so that $I\left(D_{i} \leq d i s t_{m}<D_{j}\right)$ is equal to 1 if municipality $m$ is between $D_{i}$ and $D_{j}$ minutes of commuting time from the border and 0 otherwise. This strategy produces a treatment-control type of framework as the distance of a municipality from the border determines the intensity of the received "treatment" represented by the increase in potential access of CBW. Municipalities above 30 minutes of commuting time 
from the borders did not receive essentially any $\mathrm{CBW}$ increase and therefore will be control units. Considering municipality $m$ in year $t$ as unit of observation, and calling $y_{m, t}$ an outcome in this municipality, the empirical specification we estimate is as follows:

$$
\begin{aligned}
y_{m, t}= & \beta_{d 1}^{T}\left[\text { Transition }_{t} \times I\left(\text { dist }_{m} \leq 10\right)\right]+\beta_{d 2}^{T}\left[\text { Transition }_{t} \times I\left(10<\text { dist }_{m} \leq 20\right)\right] \\
& +\beta_{d 3}^{T}\left[\text { Transition }_{t} \times I\left(20<\text { dist }_{m} \leq 30\right)\right]+\beta_{d 1}^{F}\left[F R E E_{t} \times I\left(\text { dist }_{m} \leq 10\right)\right] \\
& +\beta_{d 2}^{F}\left[\text { FRE }_{t} \times I\left(10<\text { dist }_{m} \leq 20\right)\right]+\beta_{d 3}^{F}\left[F R E E_{t} \times I\left(20<\text { dist }_{m} \leq 30\right)\right] \\
& +\alpha_{m}+\alpha_{t}+\delta \text { Controls }_{m, t}+\epsilon_{m, t}
\end{aligned}
$$

The term $\alpha_{m}$ represents a set of municipal-level fixed effects. The term $\alpha_{t}$ captures year fixed effects, which absorb the dummies $F R E E_{t}$ and Transition $_{t}$ and time variation common to all municipalities in the BR. We partition the distances within 30 minutes from the border into three groups: $[0-10),[10-20)$, and $[20-30)$ so that we can estimate a potentially decreasing effect of the "treatment" on municipalities progressively farther from the border. ${ }^{21}$ The municipalities at 30-plus minutes of distance from the border constitute the control group. In the basic specification we limit our analysis to municipalities in the border region (BR), so that the control group are municipalities in the BR at more than 30 minutes distance from the border. For some specifications we also include all municipalities in the non-border region in the control group. The term Controls $s_{m, t}$ captures time-varying economic controls that may affect labor demand in the municipalities. We always include municipality fixed effects, and region-level trends (NUTS II), which capture economic trends and fluctuations at an aggregate regional level. The main labor demand control included is a variable that captures the sectordriven growth in local employment and is commonly indicated as the "Bartik" index. ${ }^{22}$ As liberalization of trade with the EU after 2002 (see Appendix C) and differential technological growth may have affected sectors differentially, the Bartik control accounts for such sector-driven demand trends that could affect regions differently due to their pre-existing industrial structure. In other words, if employment in a given industry increased (decreased) nationally, areas in which that industry represented a significant share of employment must have experienced a positive (negative) relative change in the demand for workers relative to those where that industry was scarcely present. The Bartik control is defined at the level of the "commuting zone", which is an aggregation of municipalities often used to represent local labor markets (e.g. Favre, Lalive

\footnotetext{
${ }^{21}$ We also report all main results in the Appendix with an alternative that partitions the border regions into two bins only $[0-15),[15-30)$, see Panel I in Figure A3 and A4.

${ }^{22}$ This control was initially proposed by Bartik (1991) and Blanchard and Katz (1992) and has found wide application in the literature, e.g. Autor and Duggan (2003); Peri, Shih and Sparber (2015b).
} 
and Zweimüller (2013)). There are 106 commuting zones in the whole of Switzerland. We define the sector-driven employment growth for group $G$ in a commuting zone $c z$ in year $t$ as:

$$
\widetilde{E M P}_{c z, t}^{G}=\sum_{i \in\{1,50\}}\left(E M P_{i, c z, 1994}^{G} \times \frac{E M P_{-c z, i, t}^{G}}{E M P_{-c z, i, 1994}^{G}}\right)
$$

where $E M P_{i, c z, 1994}^{G}$ is the employment level of group $G$ (which could be, alternately, all workers or a specific education group of workers) in commuting zone $c z$ and (2-digit) industry $i$ in the earliest available year, 1994. $\frac{E M P_{-c z, i, t}^{G}}{E M P_{-c z, i, 1994}^{G}}$ is the group employment growth factor between 1994 and year $t$ for the industry nationally, excluding the commuting zone $c z{ }^{23}$ The term $\epsilon_{m, t}$ is an idiosyncratic error with zero mean and, importantly, uncorrelated with the interaction of the policy and the distance dummies. The coefficients of interest in regression (2) are $\beta_{d 1}^{T}, \beta_{d 2}^{T}$ and $\beta_{d 3}^{T}$ which capture the change in outcome during the transition period for more and less intensely treated municipalities and $\beta_{d 1}^{F}, \beta_{d 2}^{F}$ and $\beta_{d 3}^{F}$ which capture the changes during the full liberalization period for more and less intensely treated municipalities. These estimated effects are relative to the pre-policy period represented by the years 1994-1998.

\subsection{Year-by-Year Analysis}

In order to analyze without constraints the full dynamics of outcomes during the pre-, the transition- and the full-liberalization phases and to test the validity of our assumption on parallel pre-treaty trends we also estimate a year-by-year interacted specification. As described in section 2 above, some partial measures reducing the barriers to CBW mobility were enacted progressively between 1999 and 2004, and culminated in that year with full liberalization. Hence we analyze the dynamics of the reform in a regression environment, using interactions between the distance indicator dummies and each year dummy, including the whole 1994-2010 period. We omit (and hence standardize for) the year 1998 which is the last observation before the signing of the AFMP. This is implemented by estimating the following specification:

$$
\begin{aligned}
y_{m, t}= & \left.\alpha_{m}+\alpha_{t}+\sum_{t=1994}^{2010} \gamma_{d 1, t} I(\text { year }=t) \times\left[I\left(\text { dist }_{m} \leq 10\right)\right)\right] \\
& \left.+\sum_{t=1994}^{2010} \gamma_{d 2, t} * I(\text { year }=t) \times\left[I\left(10<\text { dist }_{m} \leq 20\right)\right)\right] \\
& \left.+\sum_{t=1994}^{2010} \gamma_{d 3, t} * I(\text { year }=t) \times\left[I\left(20<\text { dist }_{m} \leq 30\right)\right)\right]+\gamma \text { Controls }_{m, t}+\epsilon_{m, t}
\end{aligned}
$$

\footnotetext{
${ }^{23}$ From the list of industries, we dropped the industry 'Recycling' which was not available in all years.
} 
The variable $I($ year $=t)$ is an indicator dummy equal to one in year $t$ and zero in every other year, while the other variables are as defined in equation (2). We include year dummies, $\alpha_{t}$ and municipality dummies, $\alpha_{m}$. Since we omit the interaction term for year 1998 in the summation, the other coefficients will represent the difference relative to 1998. The estimates of the coefficients $\gamma_{d 1, t}$ for each year between 1994 and 2010 are the parameters of interest as they represent the differential of outcome between the most intensely treated group (municipalities at $0-10$ minutes from the border) and the control group (municipalities at 30 plus minutes from the Border). Another advantage is that using this specification we can test whether the year estimates are consistent with the assumptions of our identification strategy. Specifically, as the impact of the policy should be zero prior to the date it was announced, and as we are assuming that the control municipalities represent a valid counter-factual for the treated ones, we should find that $\gamma_{d 1 t}=0$, for $t<1998$. Namely, for our identification strategy to work there should be no significant different in outcomes between treatment and control municipalities before the policy. If the policy had any impact on any outcome, $y_{m t}$, then we should find a positive effect, possibly after the signing of the agreement in 1999 or after full liberalization in 2004, on the municipalities next to the border. The estimates for the $1999-2004$ years provide evidence of an effect during the Transition phase, while the estimates of the post-2004 coefficients test whether there was an effect during Full Liberalization Phase. The coefficients $\gamma_{d 1, t}$ for $t \geq 1999$ will reveal the policy effect on the most intensely treated municipalities and $\gamma_{d 2, t}$ and $\gamma_{d 3, t}$ would reveal the impact, if there is any, in moderately and weakly treated municipalities.

\section{Policy and the Intensity of CBW Flows}

\subsection{Changes in CBW Supply}

Table 2 shows the estimates for the coefficients of interest from equation 2 when the dependent variable is the number of CBW as a share of total employment in year 1998, which is kept fixed as to avoid spurious effects due to changes in native employment. As CBW comprise the group whose presence is directly affected by the policy, Table 2 establishes how the policy affected the treatment across municipalities in the two phases. In the first three rows we see the coefficients on the interaction of the "Transition Phase" with the three distance dummies, namely $\beta_{d 1}^{F}$, $\beta_{d 2}^{F}$ and $\beta_{d 3}^{F}$. In the following three rows we see the coefficient of the interaction of the "Full Liberalization" Phase with the same distance dummies $\left(\beta_{d 1}^{T}, \beta_{d 2}^{T}, \beta_{d 3}^{T}\right)$. The specification in column (1) includes year and municipality fixed effects and the Bartik index of employment as 
controls. It includes only border-region municipalities in the analysis. In column (2) we add a set of seven region-specific trends (NUTS II definition of region). In column (3) we perform the estimates including also municipalities in the non-border region as additional control group. The standard errors of the estimates are clustered at the commuting zone level (a group of municipalities that constitutes a labor market) as unobserved variables can be correlated at the local level. Let us notice that the estimated coefficients are quite similar across specifications (1)-(3), with the specification in column (2) being the one we usually adopt in other parts of the analysis. Three findings emerge clearly from these estimates. First, for the Transition period the coefficients are very small (smaller than one percentage point) and rarely significant in each distance interval. While they are prevalently positive, they are always smaller than 1.2 log points and they do not show statistical significance in the first two distance bins $(0-10$ and $10-20$ minutes from the border). Second, in the Full Liberalization phase the coefficients are positive, significant and between three and four percentage points for the first two bins. In the third bin $(20-30 \mathrm{~km})$ the coefficient is around 1.3 to 1.6 percentage points in specifications (2) and (3), denoting a small increase in CBW relative to the pre-1999 phase. This group can be seen as "weakly" treated. Finally, the inclusion or not of the NBR municipalities as controls, which is done in specification (3), does not make any difference (vis-à-vis specification 2). Considering municipalities in the BR over 30 minutes distance from the border as control is just as good as using also those in the NBR. Overall full liberalization seems to have triggered an increase in the supply of CBW by three to four percent of the employment, only in municipalities $0-20$ minutes from the border.

In the estimates of columns (1)-(3) we assume that municipalities at 30 or more $\mathrm{km}$ from the border are a good counter-factual for municipalities near the border, conditional on the control variables. In column (4) we adopt a different strategy to choose the counter-factual, and we focus only on the municipalities closest to the border, which should be the most intensely treated. In it we identify the coefficients on the interaction of the policy variables and the 0 - 10 minute distance dummy using matched pairs of "treated" and "control" municipalities. Specifically, we match each municipality in the $0-10$ minute time range from the border with another municipality in one of two control groups, the area in the border region at 30 minutes or more from the border or in the non-border region. We pool the 3 waves from the pre-reform period (1994-1998) to gain precision and match municipalities based on the variance-weighted difference in the employment share of three education and four age groups, the share of foreign workers, the share of twelve broad industry groups, the mean log wage level, and the employment 
level and density (number of workers per land area). With this approach we are able to match 327 municipalities in the $0-10$ minute area of the border region to 243 control municipalities.

We then include only the group of matched municipalities in a regression similar to 2 with only the interactions of the policy phases with the $0-10$ dummies. We additionally include as many matched-pair dummies as there are municipalities in the 0-10 interval. In this case, the coefficient on the interaction between $F R E E_{t}$ and Transition $_{t}$ and the dummy $I\left(\right.$ dist $\left._{m}<10\right)$ is estimated based only on the difference between the treated municipality and its matched control, allowing for any common unobservable factor in the two matched areas before and after the border opening. Column (4) shows the coefficients of this type of estimate. This method produces a precisely estimated zero value (0.1 percentage points) for the Transitional phase and a value close to four percentage points for the Full Liberalization phase. The change in CBW between the $0-10$ minute municipalities and their matched control is even more clearly concentrated in the Full Liberalization period, and is sizable and significant.

These results indicate that, considering two municipalities as similar as possible on several dimensions prior to 1998, and allowing for any common unobserved trend over time, the municipalities in the 0-10 minute time bin experienced a significant increase in CBW after 2004 relative to the ones at $30+$ minutes. These results also indicate that the effect arises most clearly in the Full Liberalization phase, rather than during the Transition. We will, however, describe the full dynamics of the effect when performing the year-by-year analysis.

Column (5)-(7) show the change in CBW, by education group, as percent of total employment in 1998. The estimates show that, especially for the $0-10$ and $10-20$ bins, highly- and middleeducated CBW were the groups whose supply increased more significantly, already starting in the Transition and much more in the Full Liberalization phase. Low-skilled CBW actually declined somewhat in the $0-10$ minute region in both periods. This implies that the net increase in CBW was also a net increase in relative supply of highly skilled workers for the municipalities close to the border. ${ }^{24}$ The municipality at $0-10$ minutes from the border experienced a growth of middle and high educated CBW by 5 percent of total employment and a decline in less educated CBW by 1.5 percent of total employment. Not only did more workers become available to municipalities in those areas, but they were significantly more highly educated than natives. ${ }^{25}$ Finally Column (8) of Table 2 shows the estimated coefficient if we consider the change of all foreign born, summing CBW and immigrants (I)in municipality $m$ and year $t$, standardized by

\footnotetext{
${ }^{24}$ Note that the coefficient of the three education groups (columns 5-7) sum up to the coefficient on total CBW in column (2).

${ }^{25}$ In Appendix Table A2 we show that the growth in CBW was especially concentrated among highly paid Analysts, Consultants, R\&D workers and medical occupations.
} 
the same denominator (total employment in 1998), $\frac{C B W_{m, t}+I_{m, t}}{E m p_{m, 1998}}$ as dependent variable. The results allow us to check whether the growth in total foreign-born in municipalities near the border corresponds to the growth of CBW. A smaller response of total foreign-born may suggest offsetting impacts (crowding-out) of CBW on immigrants. We find a coefficient that is somewhat larger (but not statistically different) for the $0-10$ and $10-20$ group, relative to the one in column (2) estimated for CBW. This implies slight crowding in of other immigrants, but also shows that most of the change in foreign-born in the municipalities near the border relative to those at 30 minutes plus (about $75 \%$ of it) was due, in the Full Liberalization period, to a larger inflow of CBW.

\subsection{Year-by-Year Estimates}

To visualize the exact dynamics of the change in CBW over time, we present the estimates of the year-by-year interactions with the distance dummies. We show the point estimates of the coefficients $\gamma_{d 1, t}, \gamma_{d 2, t}$ and $\gamma_{d 3, t}$ (for $t=1994, \ldots, 2010$ ) estimated from equation (3) in graphs. Figure 3, Panel A-C shows as a solid line the estimated values for the coefficients $\gamma_{d 1, t}$ capturing the changes in the $0-10$ minute distance bin, and each panel represents a different specification. In panel $\mathrm{A}$ the dependent variable is the share of $\mathrm{CBW}$ in total workers of a regression specification as in equation (3). We report also the coefficients for the $10-20$ and the $20-30$ bins in this Panel. ${ }^{26}$ Then panel D shows the separate coefficient estimates for high, medium and low skill $\mathrm{CBW}$ in the $0-10$ minutes region. As we have biannual data, we report the estimates for the even years 1994-2010, omitting 1998 (which is standardized to zero). We show the $95 \%$ confidence interval as a vertical line around the diamonds with "ticks" as boundaries of the interval. In Panel B we show the coefficients on the $0-10$ minute distance bin only, estimated using the "matching" method described above. In Panel $\mathrm{C}$ we show the regression-based coefficients as in A, but using the total foreign born change (CBW + immigrants), standardized by employment in 1998, as dependent variable. Finally Panel D shows the regression-based coefficients in the $0-10$ distance bin, when we separate highly-, middle- and low-educated CBW.

Let us emphasize that the behavior of the $0-10$ minute coefficients are similar in Panels A-C and some features stand out. First, in the pre-1999 years, none of the estimates for any of the time bins is significantly different from zero at the $95 \%$ confidence level. The estimates for the

\footnotetext{
${ }^{26}$ In these specifications, we estimate equation (3) only for municipalities in the border region, including as controls a full set of municipality and year fixed effects, NUTS II-specific trends and the Bartik index of employment. We performed other variations, e.g. including municipalities in the non-border region in the control group, which give similar results. See Online Appendix Figure A2.
} 
0 - 10 bin show some fluctuations from 1994 to 1998 both for CBW (Panel A, B) and for total foreign born workers (Panel C) but none significantly different from zero. The $10-20$ minute coefficients are similar to those for the $0-10$ interaction, showing a similar time behavior. This is consistent with the fact that before the reform of 1999 there was no differential growth in the share of CBW in the municipalities near the border relative to others. Second, the $20-30$ coefficients for the CBW supply are small throughout the period 1994-2010, implying smaller changes for CBW in this distance group even in the Full Liberalization Phase. Thus, the trend for $C B W$ in this bin is not very different from that of the control group (more than 30 minutes) which received no CBW. When considering all foreign-born (in panel C) the $20-30$ coefficients show a stronger upward trend after 2004, denoting the possible larger inflow of immigrants in this bin. Third, there is a weak upward trend in the 1999-2004 years (panel A and B), with an estimated increase in the CBW share of the population between one and two percent. ${ }^{27}$ Hence, the coefficients on the $0-10$ minute bin shows some mild increase already during the transitional phase, but the individual coefficients do not rise to a statistically significant level. It is hard to say whether the anticipation or the initial measures started having an effect already in the 1999-2004 period, but we can say that any effect was minor. The most important and clear fact is that after 2004 the coefficient on the $0-10$ and on the $10-20$ minutes bins grew consistently (see Panel A and B and C) becoming significantly different from zero with positive and significant point estimates in 2006, 2008 and 2010, when the full liberalization of CBW was in place. The point estimate for Panel A, in 2010 is about 0.08 , implying that CBW workers increased by 8 percentage points of initial employment between 1999 and 2010. Most of this growth was after 2004. The coefficient for the 10-20 minute bin in panel A (triangles connected by the dashed line) shows a similar growth and an upward trend since 2004, reaching a value of 0.06 in 2010. The estimates for total new immigrants in Panel C, show similar patterns, except that the coefficients on the 20 - 30 minute bin show some positive and more significant effects, revealing inflows of resident immigrants to this region especially after liberalization of resident immigrants in 2007.

The estimates reported in Panel D provide additional information and confirm two important characteristics of the CBW increase after 1999. First, we see that the post-1999 growth of CBW in the $0-10$ distance range (the only coefficient reported) is due to the increase of middle and highly educated CBW (dark and medium dashed lines). Their pre-1999 trend was very flat and

\footnotetext{
${ }^{27}$ When compared to 1998 , the point estimates of 2002 and 2004 for the $0-10$ bin seem to reveal a positive deviation. However, if one compares them with an average pre-1999 (1994, 1996 and 1998) there is really no deviation (as shown in Table 2).
} 
their growth took off, significantly, only after 2004. Second, the growth of low-skilled CBW remains close to zero (light dashed line) over the whole period, with possibly even a decrease relative to the pre-1999 period. The noise of the data for low-skilled CBW, and the fact that their coefficient remained rather flat for most of the period, suggests that this group remained at pre-1999 level of mobility. The Transitional phase and the Full Liberalization of CBW therefore implied a clear increase in supply in medium- and skilled CBW but not in less-skilled ones. ${ }^{28}$

An additional feature of the $\mathrm{CBW}$ changes reported in Figure 3 is worth emphasizing. The supply of CBW in municipalities 0 - 10 minutes from the border increased progressively starting in 2004. Clearly there was no immediate "jump" produced by free CBW movement, but rather a progressive growth in their share of employment from 2004 to 2010. Likely, the opening of the border made firms recognize opportunities to hire new highly skilled CBW and it encouraged them to create more jobs, slowly affecting their employment. This emphasizes the importance of analyzing the "total" rather than "partial" effects of immigration over time, which accounts for several margins of adjustment. The dynamics of capital investment, the transition of natives across occupations, firms' growth and birth of new firms occurred at the same time as the CBW inflow took place, and in anticipation and response to that inflow. Hence the comparison of outcomes with the changes in CBW across years produces a picture of simultaneous adjustments in response to a cumulated increase of immigrants. What is new in this paper is that we can analyze first the effect of the immigration policy on immigration flows before analyzing the consequences of immigrants on natives. Our study, and the work of Ruffner and Siegenthaler (2016), are among the very few (as far as we know) that track the effects of a permanent immigration policy change in a developed country. Our focus is on the analysis of its consequences both on immigrants and on labor market outcomes and on the internal migration and inter-sectoral and inter-job dynamic adjustment of native workers. The work of Ruffner and Siegenthaler (2016), complementary to this, analyzes the impact on firm creation, innovation, R\&D and productivity. ${ }^{29}$

\footnotetext{
${ }^{28}$ In Appendix Table A2, we report the change in the number of CBW (relative to total employment in 1998) for 24 separate occupation categories in the SESS data. This shows that the largest contribution to the overall increase in CBW came from middle and highly-paying occupations, particularly from occupations entrusted with reviewing/consulting/certifying, R\&D, analyze/program/operating and medical occupations.

${ }^{29}$ The paper Dustmann, Schönberg and Stuhler (2017) instead considers a temporary change of cross-border workers in Germany (reversed after two years) leading to inflow of mainly unskilled workers in a period (1991-1993) of deep crisis in Eastern European institutions and markets.
} 


\section{Effects on Native Labor Market Outcomes}

\subsection{Effects on Native Wages}

The findings in the previous section establish that by 2010 the policy of free labor market access for CBW increased their supply by about four to five percentage points of employment in municipalities within a $0-10$ minute commute from the border. It also increased their supply by a similar amount in municipalities $10-20$ minutes from the border. Beyond that commuting time, the effects on CBW supply are one percent or smaller. Tertiary and secondary-educated CBW were the groups responsible for the whole increase. Did this result in depressed wages or employment for highly-skilled natives? Were the wages of other groups of workers affected through complementarity? Or did firms respond by creating jobs for highly-educated and absorb the larger supply of CBW? And did native workers respond by moving from close to the border to other areas? Or by changing jobs? And which industries were more affected?

To answer these questions, we first analyze the effect of the policy changes on wages, employment, and hours worked by Swiss natives in aggregate. We estimate a regression in the form of equation (2) with municipalities as units and the average logarithm of native hourly wages as the dependent variable. ${ }^{30}$ We show the main estimated coefficients interacting the policy phase and the distance bins in Column (1) and (2) of Table 3a. If one thinks of the change in supply of $\mathrm{CBW}$ as the dependent variable and of the policy dummies interacted with distance bins as the instrument, then the coefficient reported are those from a reduced-form IV regression. The coefficient estimates represent the intention-to-treat effect (ITT) and the treated groups are the $0-10$ and $10-20$ minute bins. The point estimates of the impact on native wages can then be used to derive the elasticity of their response to the change in the supply of CBW, estimated in Table 2, dividing the first coefficient by the second. Column (1) shows estimates from the specifications with all controls and including only municipalities in the Border Region. Column (2) shows the estimates when NBR are included in the control group. ${ }^{31}$ Table $3 \mathrm{~b}$, then shows the coefficients estimated separately by education group. Column (1) in Panel A in Table 3b

\footnotetext{
${ }^{30}$ Table A3 in the Appendix shows the estimates using log of monthly wages as dependent variable. Monthly wages are originally collected in the SESS. The results are similar to those obtained using log hourly wages.

${ }^{31}$ When we consider wage as outcome we use a Bartik measure also based on national wage growth:

$$
\widetilde{w_{c z, t}}=\sum_{i \in\{1,50\}} s_{i, c z, 1990}\left(w_{i, c z, 1994}^{G} \times \frac{w_{-c z, i, t}^{G}}{w_{-c z, i, 1994}^{G}}\right)
$$

where $w_{i, c z, 1994}^{G}$ is the initial log hourly wage payed in (2-digit) industry $i$ for education group $G$ in commuting zone $c z$ in the first available wave in 1994 and $\frac{w_{-c z, i, t}^{G}}{w_{-c z, i, 1994}}$ measures industry wage growth for that group on the national level (excluding commuting zone $c z$ ). Wage growth is aggregated using each industry's employment share in $1990 s_{c z, i, 1990}$ taken from the national Census.
} 
uses average log hourly wage of highly-educated natives as the outcome. Column (1) of Panel B and Panel $\mathrm{C}$ does the same for middle educated and low educated native workers, respectively. ${ }^{32}$ The point estimates of Table 3b show the "total" effect of immigrants on the wage of each education group of natives. Those of table $3 \mathrm{a}$ show the total effect on average native wages. The coefficients captures the impact on native wages both from competition of CBW with similar skills and from complementarity from CBW with different skills. ${ }^{33}$

Inspecting the estimates of Table 3a, the first consideration is that the effects on the average wages in the $0-10$ and $10-20$ minute bins are very small and never significant both in the "Transition" and in the "Full Liberalization" phase. The point estimates for the $0-10$ and $10-20$ bins are usually positive but small (never larger than 1.8 log points) and never significant at the $5 \%$ confidence level. Since we found that the post-2004 liberalization increased the share of CBW by about four to five percent of the employment in bins at $0-20$ minute distance, the implied elasticity for the average wage effect is compatible with values between -0.3 and 0.3 , using the estimates of the $0-10$ and $10-20$ interacted with Full-liberalization. Given the standard errors, a zero effect cannot be rejected at any level of confidence. An explanation based on a classical model of "change in supply for fixed demand" does not work well in this case (as there is no evidence in the short run of a negative effect). This is even clearer when we look at the impact by education group shown in Table 3b. As documented above, Full Liberalization produced a larger inflow of highly educated CBW relative to lesseducated ones. Hence the canonical "partial effects" model would imply a negative wage effect on highly-educated natives and positive effects on low-educated ones. To the contrary, the most significant effects, which are robust across specifications, are reported in column (1) of Panel A of table $3 \mathrm{~b}$ and show a positive positive coefficient on the wages of the highly-educated in the Full Liberalization phase, in the order of $+4 \%$ in the $0-10$ and the $10-20$ minute bins. The coefficient is positive but not significant (equal to 1.6\%) for the $20-30$ minute bin. Smaller positive effects, especially in the $0-10$ minute bins appear already in the Transition phase. At the same time, no wage effects are significant at the 5\%-level for the middle educated and for the low educated (Panel B and C, Column (1)). Some point estimates are estimated to be negative in any of the phases. The changes in wages of highly-educated natives are consistent

\footnotetext{
${ }^{32}$ The random sampling of the SESS implies that some municipalities have missing information for the dependent variable of some education groups. This explains the difference in the number of observations across education groups (panels) of a particular specification in the Table 3b and also in Table 3a. We found similar results when dropping municipalities below the 20th percentile of aggregate employment each year or dropping municipalities that had missing information in aggregate employment in any year. These results are shown for log hourly wages and total hours as dependent variables in the Appendix Tables A4 and A5, respectively.

${ }^{33}$ See Ottaviano and Peri (2012) for a more formal argument about the estimation of a total effect of immigrants aggregating all the direct competition and indirect complementarity effects from different skill groups.
} 
with a causal effect of the increase in CBW, but not with a simple neoclassical model. The channels of this complementarity/productivity effect can be several. We suggest three of them here that have been recently proposed in relation to immigrants. First, a larger supply of CBW pushes firms to expand and create new jobs (as in a search model à la Chassamboulli and Palivos (2014)) with some of those jobs filled by natives. Second, firms' return to investing in equipment capital and new technologies that complement the skills of CBW increases, and investment enhances productivity of native workers too (as in Lewis, 2011, Lafortune, Tessada and Lewis (2015) or Peri (2012)). Finally, local human capital externalities of the type analyzed in Moretti (2004a,b; 2010), and occupational upgrading of native highly skilled jobs as described in Peri and Sparber (2009), could increase productivity through learning, higher efficiency and technological adoption. Such models can generate increases in productivity for groups whose supply increases. Increased productivity and job creation for high skilled natives are also consistent with the firmlevel evidence presented by Ruffner and Siegenthaler (2016) and reviewed in Section 6.5 below.

The estimates for the full dynamic year-by-year interactions with distance bins are shown in Figure 4 Panels A-D. The panels show the year-bin coefficient estimates for the $0-10$ minute bin only and the $95 \%$ confidence interval obtained from specification (3) with the average logarithm of native wages as the dependent variable in Panel A, the log wage of highly-educated natives in Panel B, and the same wage measure for middle- and low-educated natives in Panels $\mathrm{C}$ and D, respectively. The estimated coefficients for the $[10-20)$ minute region are similar. ${ }^{34}$

There is some variability in the estimates before 1999, but there is no evidence of a systematic pre-trend. None of Panels A-D, show evidence that the intensely treated municipalities $(0-10$ bin) had a systematically different wage trends relative to the control group before 1999. This is consistent with our identifying assumptions. For the aggregate log wages we observe a small and non-significant drop in 2004 (the point estimate is half the size of the standard error) and no change after then. This amounts to no evidence of an average wage effect. Panel B, relative to highly skilled wages, shows instead positive and significant coefficients after 2004, reaching about four to five percent by 2010. The timing and scale of the effect is consistent with a positive effect of CBW on productivity of high skilled Swiss workers with a semi-elasticity of about one (namely an increase of CBW of one percent of employment produces a one percent wage increase). The other two groups of native workers (middle- and less-educated) have smaller and non significant wage changes, with the low-educated experiencing a drop between 2000 and

\footnotetext{
${ }^{34}$ In the reported figures we estimated the equation (3) only for municipalities in the border region and we always include a full set of municipality and year fixed effects, region-specific trends and an education-specific Bartik index for wages.
} 
2004 and a more mixed path between 2004 and 2010, while the middle educated have a small drop in 2004 as well. Yet this change is also not significant statistically. ${ }^{35}$ Combining evidence from Tables 3a, 3b and Figure 4, we find consistent evidence of a significant wage increase for highly-educated natives in the areas where and periods when CBW increased as a consequence of the new policies. Both middle-skill native workers and native workers as a whole did not experience any significant effect. Less-skilled workers possibly experienced a small, negative, still not significant effect.

\subsection{Effects on Natives' Employment and Hours Worked}

A second important aspect of the potential labor market effects of CBW is the impact on native labor supply. While positively affecting productivity of high skilled natives, did CBW displaced labor supply of native workers? We measure this variable as the logarithm of total number of native workers or, alternatively, as the logarithm of total hours worked by natives. The first measure captures only the extensive margin of labor supply, while the second combines the extensive and intensive margin. Table 3a, columns (3) and (4) shows the coefficients of interest for total native employment and columns (5) and (6) for total native work hours, respectively. Table 3b, panel A, Columns (2) and (3) shows the same effects when considering only highlyeducated natives, Panel B when looking at middle-educated natives and Panel C for low-educated only. Figure 5 plots the coefficients estimates from regressions as specified in equation (3) for time bin $0-10$ minutes, with total hours worked by all natives as the dependent variable in Panel A and by education group (Panel B-D), respectively. ${ }^{36}$ The estimates for employment and hours worked are somewhat noisy and the standard errors can be as large as 6 percent and sometimes they exceed 15 percent for the small group of less-educated. They, however, never show evidence of an "crowding out" effect on native employment or native hours worked (which would imply negative and significant coefficients). The point estimates for the aggregate employment and hours effects during the Full Liberalization period are not significant and are usually positive (see also Figure 5, Panel A). For individual education groups, we see some positive and significant coefficients on the highly-educated employment and working hours mainly in the $20-30$ bin, which was only weakly treated. This may imply some spillover effects from the bins closer to

\footnotetext{
${ }^{35}$ We find qualitatively similar results when we use two alternative definitions of workers' skills and when we use two distance bins ( $0-15$ and $15-30$ minutes) only. Figure A3 shows the year effects for 15-minute distance partitions (Panel I) and for wage tercile and occupation based partitions (Panel II and III). In all cases, the effect on highly skilled wage is positive and usually significant for the region closest to the border in the post-2004 years. For the other two education groups, the effects are usually close to zero and insignificant.

${ }^{36}$ The regressions used to obtain the coefficients of Figure 5 includes year and municipality fixed effects, regionspecific trends and education group specific Bartik index for log total hours as specified in equation (2).
} 
the border into the $20-30$ bin, which we will explore in the next section. For less-educated, there seems to be a positive but not significant (noisy) effect near the border for employment and hours worked. The increase in employment and hours worked by less-educated natives can suggest an increase in the demand for their services resulting from the complementarity with the services of skilled CBW. This demand could have triggered a rather elastic labor supply response of less-skilled workers without affecting their wages much. The estimates, however, are not significant at standard confidence levels and so we should take them with caution.

Altogether, the estimated wage and employment coefficients are consistent with a positive complementary/productivity effect of CBW on high skilled native workers. Moreover they do not suggest crowding out, or pure competition from CBW. In particular, the positive and significant effect on the wages of highly-educated and the null to positive overall effects on their employment are at odds with pure competition effects that would prevail in a canonical neoclassical model. In order to understand better the channels of response of native workers and firms that allow such a positive impact on native workers, we analyze in greater detail some specific transitions of native workers into and out of employment, and between jobs or regions.

\subsection{Robustness Checks}

To further alleviate the concern that unobserved variables may create a bias in the estimates of the effect of CBW in the wage and employment regressions, we perform several robustness checks, reported in Appendix Tables A6a for aggregate variables and A6b, panel A-C, for skillspecific groups. As a first check, shown in that Table in columns (1) and (5), we estimate our baseline specification (2), using less conservative standard errors, clustered at the municipality level instead of the commuting zone level. Compared to the baseline estimates above (in columns (1) and (5) of Tables 3a and 3b), however, this check leads to almost no change in the significance level of the coefficients. Second, while we found no evidence for a pre-1999 trend and our baseline specification already includes separate trends for the seven NUTS II regions, columns (2) and (6) allow for a separate trend for each of the 26 Cantons in Switzerland. Adding the canton-specific trends we observe a small decrease in the positive $0-10$ and $10-20$ wage coefficient on high skilled during the Full Liberalization period and a small increases in the $10-20$ and $20-30$ employment and hours coefficient. However, the differences are minor. A third robustness check has to do with the concern that the economies of large cities near the border, such as Geneva, Basel and Lugano, may drive the whole "attraction effect" for CBW after Full Liberalization. Hence, we estimate a specification excluding border cities in Columns (3) and (7) of Appendix 
Table A6a and A6b. This change does not have any significant impact on the results. Finally, to test whether the main results in the municipalities closest to the border are robust to the choice of an alternative control group, we use the matching method, for the municipalities in the $0-10$ minute region, and we match them with most similar ones in the +30 min region. The estimated coefficients are significantly positive for the high skilled wage effect after full liberalization, confirming that the positive productivity effect of CBW on that group seems the strongest result of our wage and employment analysis.

\section{Native Workers' Transitions and Adjustment Mechanisms}

\subsection{Spillovers Due to Internal Migration}

As municipalities are small open economies, part of the effect of a larger supply of CBW may spill over to other municipalities in different ways. Of particular interest is how inflows of CBW may affect the ways Swiss workers move to other municipalities nearby or in the rest of Switzerland, and how they may affect the inflow from other Swiss municipalities. A significant movement of Swiss workers to other municipalities, possibly within the border region but farther from the border, may affect the municipalities farther than 30 minutes from the border and hence question our assumption that they are a valid control group. Past research (e.g. Card and DiNardo, 2000; Peri and Sparber, 2011a) has not found significant outflows of natives in response to immigration. However, recent papers (e.g. Dustmann, Schönberg and Stuhler, 2017) have suggested that inflows of natives from other areas may be reduced following immigration, producing a "crowding out" of potential natives who would have moved into the region.

In table 4 we show the key findings about the changes in net flows (column (1)) and inflows (columns 2 and 3) and outflows (columns 4 and 5) from/to other Swiss municipalities in the Full Liberalization period. Additionally we divide these flows between municipalities within the 30 minute range from the border (columns 2 and 4) and those farther than 30 minutes (columns 3 and 5). For compactness, we only report the coefficients in the Full liberalization period, first considering all workers (panel A) and then the three education groups separately (Panels B-D). Results in the Transitional period are weaker and reported in Appendix Table A7. In Table 4 the dependent variable for each column is a different flow into or out of a municipality during a year, standardized by the initial employment of the municipality $m$. Hence the dependent variable is a migration/rate as percent of employment.

To construct these variables, we use the Swiss Labor Force Survey (SLFS) as a complemen- 
tary data set. Most individuals in the SLFS were interviewed for two consecutive years, and we can calculate the flow variables at the municipal level using the employment status and the place of work for each individual in the previous or the next year, respectively. ${ }^{37}$

Panel A of Table 4 shows that the coefficients on net flows (column 1), inflows (columns (2) and (3)) and outflows (columns (4) and (5)) for all Swiss workers are very small and never significant. This implies that there is no sign of spillovers effect or indirect impact on potential movers during Full Liberalization. When looking at the highly educated, which is the only group for which we find a robust wage effect, in panel B of Table 4, we see no significant coefficient for the net migration nor for gross inflows or outflows from/to the area within 30 minutes from the border (columns (2) and (4)). There is one coefficient which is significant for the inflow and outflow of workers from/to regions at more than 30 minutes from the border. These are for the 10 - 20 minute bin, and they have the same sign and similar magnitude, implying smaller inflows and smaller outflows of similar amounts and so, in net, no effect. Hence there is no significant evidence that net flows of highly educated Swiss workers between treated municipalities and any of the considered distance bins has played a significant role in the adjustment. In panel $\mathrm{C}$ we see no evidence of net flows for middle educated while for less educated there is one positive coefficient on net with the municipalities at $10-20$ minutes from the border. This may be somewhat consistent with the positive (albeit only not marginally significant) employment effect showed in Table $3 \mathrm{~b}$ on employment. The lack of a clear distance pattern and the imprecision of some of the estimates in panel D, however, do not support too strongly the idea of a significant internal migration response of less-educated workers. All estimated changes in net flows are small and are unlikely to have any impact on the average control municipalities (in the regions at more than 30 minutes from the border). Overall, the inflow of CBW who were mainly highlyeducated increased their supply in municipalities very close to the border without creating a "domino" or "spillover" effect of native internal migration towards other part of the country. We also note here that the flows of Swiss workers from the border region to outside Switzerland (as commuters or migrants in the reverse direction from the one considered in the paper) were negligible, as the wage differential between Switzerland and municipalities in other countries near the border is large (up to $30 \%) .{ }^{38}$

\footnotetext{
${ }^{37}$ Due to a structural break in this data from year 2010 onward, we only use the years 1996 to 2009 (on a yearly basis) when computing flow variables between two consecutive years (e.g. in Table 4 or Appendix Table A7). In contrast, when we exploit the cross-section information as below in section 6.2 (in table 5), we also include the year 2010. We only use the SLFS to analyze additional mechanisms and worker transitions as the data set is much smaller than the SESS, which we use for our main analysis. Nevertheless, we replicated all our main results using the SLFS and all results were qualitatively similar. See Appendix B for more details on the exact calculation of the flow variables.

${ }^{38}$ In fact, aggregate statistics collected by the Federal Statistical Office suggest that the absolute number of
} 


\subsection{Moving up the Management Ladder}

Internal geographical mobility was not significantly affected by the increase of CBW. What, then, were the mechanisms put in motion to absorb the new workers and to produce the observed wage/productivity effects on high skilled Swiss workers? We explore here several alternatives, beginning with the different specialization between CBW and native Swiss workers and the occupational response of natives. As shown above, highly educated CBW were primarily employed in Technical/Scientific and Engineering type of jobs. One possibility is that, in companies hiring CBW, we may observe an incentive for highly educated Swiss workers to move towards the high end of managerial jobs (see a similar phenomenon in Peri and Sparber (2011b) and Peri, Shih and Sparber (2015b)). Positions in the top organizational tiers of management require knowledge of local culture, laws and norms, and possibly a local network of contacts. Those are more accessible to a native than to a foreign individual. ${ }^{39}$ The demand for top managerial jobs grew as firms became larger and more productive, as hiring CBW as STEM workers was a way to grow. Hence we analyze whether natives, especially highly-educated ones, were more likely to become high-level managers in the executive board of Swiss companies after the introduction of free mobility of CBW. To do this, we use a question in the SLFS that identifies if worker is in the top executive level ("Direktion/Geschäftsleitung") of a firm, which we consider as top management of the firm.

Table 5 uses as the dependent variable in columns (1) and (2) the share of native workers in executive boards (i.e. in the top tier of management) relative to native employment. Column (3) and (4) use instead the log number employed and the log hours worked by natives in those top managerial positions. For compactness we show the coefficients on the interaction between the Full Liberalization period " $F R E E_{t}$ " and the two distance bins closer to the border, $(0-10]$ and $(10-20]$ which were more intensely treated. We partition the results in panels reporting the estimates for all workers at the top (Panel A), and then proceeding down the Table, for highly-educated workers (Panel B), middle-educated workers (Panel C), and for less-educated workers (Panel D), respectively. We find that for highly-educated and middle-educated there was a significant increase in the share of natives in the top tier of management in the $0-10$ or in the 10-20 minute bins. Employment and hours worked in those jobs (column 3 and 4) also increased significantly for highly educated. ${ }^{40}$ The effect on middle-educated is not significant for workers

\footnotetext{
Swiss cross-border workers commuting for work abroad increased a bit since 2002 but still constitutes a negligible share of total employment (Swiss Federal Statistical Office, 2015).

${ }^{39}$ Appendix Table A10 shows that CBW usually work in language region where they speak the local language. Thus language may not "per se" be a significant source of comparative advantage. Institutional and local knowledge, though, can be just as important in creating specialization and relative advantages.

${ }^{40}$ The latter two effects imply that the change in share of managers must be driven by the entry of individuals
} 
and hours (column 3 and 4). We infer that for this intermediate group the response is not as clear as for the highly-educated. For less-educated the impact is negative or null, but on average a very small share of these workers is in management positions so that in aggregate the effect on this group is very small. These estimates are consistent with the idea that, due to complementarity with $\mathrm{CBW}$ and productivity growth in the firms, native workers were more likely to become top-tier managers in firms that hired CBW as technical and scientific professionals. By moving to those jobs, natives' wages increased, and this accounts for a portion of the increase in the wage found for this group in Table $3 \mathrm{~b}$.

In Table 6 , we show more precisely what part of the highly educated wage effects can be attributed to higher top management wages and to a larger share of natives moving to top management positions. In the first column we reproduce the estimated effects on the "Full Liberalization" dummy interacted with distance bins on the wage of highly educated native workers. Then we show the impact on wages in top management (column 2) and in nonmanagement (column 3) positions. We see that the positive effect is $30 \%$ stronger on top management position, which likely benefit more of the improved hiring and expansion of firms' productivity and scale because of CBW. This already suggests a stronger complementarity of top management with CBW. Column (4) show the wage increase in highly educated if the share of natives in top-management positions is kept constant at the pre-1999 level. This specification controls for the reallocation of natives towards top management. We see that the effect is $20 \%$ (in the $0-10$ bin) to $45 \%$ (in the $10-20$ bin) smaller than in column (1). This implies that a non negligible share of the wage growth of natives is simply due to the reallocation of highly educated natives towards high management positions. An important margin of adjustment for highly-educated Swiss workers was to transition towards managerial positions as highlyeducated CBW took technical, math-intensive, and engineering type of jobs. This upgrading to high management is a form of occupational upgrading among natives that seems often triggered by immigration. For instance, Cattaneo, Fiorio and Peri (2015) for countries in the European Union and in Foged and Peri (2016) for Denmark have shown that native workers upgrade their occupations in response to immigration by moving into more complex types of jobs.

A further piece of evidence confirming that the wage gains for highly educated are in part driven by upgrading to managerial positions is provided in Appendix table A9. We show the coefficients on the wage and hours worked by highly educated across demographic groups, sep-

into management positions rather than the exit of non-managers in highly exposed areas, as employment and hors worked by this group increase. In unreported results, we found no effect on the employment and hours of non-managers. 
arating male and female workers, old (more than 38 years) and young workers, and workers with high (more than 6 years) and low tenure at the current job. The strongest results are for changes in hours worked by different sub-groups among highly educated. Supporting the hypothesis that CBW stimulated demand for natives in top managerial positions, males, older workers, and those with longer tenure are the groups experiencing a larger and more significant increase in hours worked. These are the groups more likely to be in managerial positions in the Swiss economy. Higher demand for highly-educated males and highly-experienced natives is consistent with the upgrading story at the top of the managerial ladder. It is likely that complementarity between CBW, who specialize in technical and scientific skills, and top management/administration increased wages and demand of older, highly-skilled, and mainly male workers. This is the strongest and most consistent effect found in the paper.

\subsection{Sector-Specific Productivity Growth}

An important dimension of the heterogeneity of the CBW effect is their different presence across sectors. As they were heavily employed as IT professionals, engineers, and scientists, this implies a larger direct impact on productivity growth in the sectors that use these skills more intensively. Those are the high-tech manufacturing sectors and the more knowledge-intensive services (finance, business, human resource management). If native workers are, at least in the short term, not perfectly mobile across sectors due to search and matching frictions (Rogerson and Shimer, 2011) or industry- or firm-specific human capital (Neal, 1995), the inflow of CBW may have affected wages differentially across sectors and more in those experiencing larger inflows.

Table 7 shows the coefficients on the relevant interaction (between $F R E E_{t}$ and the most intensely treated groups $0-10$ and $10-20$ ) when the dependent variable is the log of native wages for workers in different sectors. In column (1) the sector is high-tech manufacturing, while in column (2) it is low-tech manufacturing. ${ }^{41}$ In column (3), the sector is knowledge intensive services, and in column (4) not-knowledge intensive services. ${ }^{42}$

The first two rows of Table 7, indicated as Panel A, shows the post-liberalization change in

\footnotetext{
${ }^{41}$ We follow the Eurostat classification of industries and define high (and medium-high)-technology manufacturers as industries with NACE Rev 1.1 code 24, 29, 30, 31, 32, 33, 34 and 35 excluding 351. Broadly speaking, this includes producers of pharmaceuticals, IT, air/space-craft and other high-tech machinery and electronics. Lowtechnology manufacturers are the remaining manufacturing industries, e.g. producers of textile, raw-material, food, repair industries etc

${ }^{42}$ Knowledge-intensive services are NACE Rev 1.1 industries 61, 62, 64, 65-67, 70-74, 80, 85, 92, e.g. financial intermediation, education, research and development etc. Not-Knowledge intensive services are the remaining service industries, e.g. wholesale and retail trade, hotels and restaurant, transport etc. Agriculture, mining and construction is omitted from this table as these sectors are very small and the effects were never significant.
} 
$\mathrm{CBW}$ as the share of employment into the specific sectors at $0-10$ and $10-20$ minutes from the border. Then in Panel B we show the post-liberalization change in average log wages for all native workers in the same distance bin. Panel $\mathrm{C}$ shows the change for highly-educated native workers, and Panels D and E show the effect for middle- and low-educated ones, respectively. In each column/panel, we estimate a specification as equation (2) including year and area fixed effects, Bartik controls, and regional trends. We only report the coefficient on the interaction between "FREE" and the $[0-10)$ and $[10-20)$ distance bin, which are the most intensely treated bins.

The post-liberalization period was characterized by a much larger inflow of CBW in high-tech manufacturing $(+5.8$ and +4.4 percent in the two distance bins) and knowledge intensive services $(+5.1$ and +3.9 percent $)$ than in other sectors. These heterogeneous inflows are consistent with the idea that CBW were mainly employed in high-tech manufacturing and knowledge-intensive service sectors. Hence, those sectors are also where we expect the strongest complementarity effect with native workers.

When looking at sector-specific wage effects on native workers combining all education groups, the only significant coefficient at the $1 \%$ level is the one on wages in the high-tech manufacturing for workers in the $0-10$ minute bin. Also positive, non-negligible in magnitude but not statistically significant is the coefficient on knowledge-intensive sectors (close to $10 \%$ significance for the $10-20$ bin). The coefficients on low-tech manufacturing and on knowledgenon-intensive services are negative and almost significant. These estimates are consistent with higher productivity brought by CBW in high-tech and knowledge intensive companies. The particularly strong effect in high-tech manufacturing is also consistent with the results in Ruffner and Siegenthaler (2016) who show that CBW increased the R\&D and the innovation done in firms: the effects they found were particularly strong in high-tech firms. Interestingly, when we separate by skill, the positive wage effects in this sector seem stronger for middle- and lesseducated native workers who are likely to be complementary to the technical skills of CBW. When we break the estimates further down by education groups, we find a positive wage effect in the order 5.7 percentage points at $0-10$ minutes from the border for highly-educated in knowledge-intensive services. To the contrary, less-educated workers in services may have experience a wage loss of around three percentage points near the border.

Table 8 Panels A-D, shows a set of industry-specific coefficients, similar to those shown in Table 7 , on $\log$ of hours worked by natives. These captures possible shifts in labor supply by natives in response to CBW across those sectors. Expansion and increased productivity 
at the sector level may imply a larger labor supply of native workers. While the coefficients are mostly non-significant, there is some evidence of a positive effect on the hours worked of high-educated in high-tech manufacturing and of less-skilled natives in services that are not knowledge-intensive. This last effect may be driven by positive job-multiplier effects (as described by Moretti (2010)) on local, low-skill services, and support companies (e.g. hotel, food, hospitality industries) attracted by the growth of high tech manufacturing and services. The positive effect on employment and zero (or even negative) effect on the wages of low-educated natives in this sector is consistent with a highly elastic labor supply for these jobs that require very generic skills, and a possible negative selection in the sector.

In all the existing regressions we have focused on private sector employment. it is however interesting to mention another possible margin of adjustment. In Appendix Table A8 we show the impact on employment in public sector workers. These are estimated using data from the Swiss Business Census (BC), a different database, which includes, differently from the rest of the paper, public-sector workers. A significant effect shown in this table is the tendency of native workers to move towards public sector jobs in response to CBW. There is a significant, albeit small, shift of about one percent of native employment moving from the private to the public sector after the liberalization. This transition could be an additional channel through which natives protected their wages from immigrant competition, as native have easier access than immigrants to public jobs. We do not know of other studies that analyze this margin, which can be important in some European countries.

\subsection{Effect on Firm Creation}

The positive productivity effect from CBW, consistent with higher wages and employment of natives, and particularly clear in high tech manufacturing and knowledge intensive service sector, may also derive from a complementarity of these workers with capital investments. Their presence, and the perspective of hiring them, may have attracted new establishments in the region near the border, producing the growth of employment and wages we observed. The prospect of hiring the right type of workers can be a very strong attractor for firms and a key driver of agglomeration economies (as in Moretti, 2004). In Table 9 we consider the creation of new establishment, as a share of total establishment in the sector in 1998, during the Transition phase and during the Full Liberalization phase, in the four sectors considered above (high- and low-tech manufacturing in columns (1) and (2), and sectors that were and were not knowledgeintensive in columns (3) and (4)). The estimates show the largest positive firm creation effects 
during the Full Liberalization period (coefficients of the "FREE" variable). It appears that such firm-creation was quite widespread across sectors, although stronger in high-tech manufacturing and in Knowledge-intensive services, in line with the previous results. The aggregate effect is an additional creation of new establishments by 3.4 percent in the bin closest to the border, by 2.8 percent in the bin at $20-30$ minutes and a little bit less in the $10-20$ bin.

During the Transition we also find a (smaller) effect of between one and two percent higher firm-creation in aggregate. This is consistent with the idea that anticipation of a larger supply of CBW may have attracted new investment and new firms already in the transition. The sector distribution of the effects during the transition shows noisier and less precisely estimated coefficients. It suggests that the high-tech manufacturing and service sector experienced the largest entry of new establishments relative to the initial number of firms in these sectors. ${ }^{43}$

Summarizing the role of different channels we have shown that internal migration and mobility have not played a particularly relevant role in response to the opening to CBW. Instead, upgrading of natives to managerial positions, gains in productivity in high-tech and knowledge intensive services, and attraction and birth of new firms have been stimulated by the policy, especially during the phase of full mobility. Together these channels are consistent with the wage increase of highly skilled natives estimated after allowing free mobility of CBW.

\subsection{Comparison with Recent Similar Studies}

Before concluding, we systematically compare our results with those of two recent papers related to this one and point out similarities and differences. The first study from Ruffner and Siegenthaler (2016) was developed concurrently to this paper and focuses on the same episode of liberalization in Switzerland. Ruffner and Siegenthaler (2016) use firm-level data and focus on firm outcomes: labor productivity, sales, R\&D investments, innovation, and firm entry and exit after CBW liberalization. They provide results that are complementary to those presented in this paper. First, they show that firms close to the border experienced an increase in aggregate employment and an expansion in sales and a mild increase in productivity post-liberalization. The authors also document that firms expressing worries about shortages of highly-skilled workers in the pre-liberalization period (via a survey) experienced larger increase in sales and in value-added per workers following the liberalization. This confirms that the expansion of CBW supply may have facilitated growth, investment, and productivity gains. Second, firms that benefited most with respect to productivity and growth were those in the high-tech sector, larger

\footnotetext{
${ }^{43}$ These results complement the findings of Ruffner and Siegenthaler (2016) who also find positive effects on firm entry and no robust effects on firm exit close to the Swiss border.
} 
firms, and those previously dependent on cross-border workers. This result is consistent with the stronger positive wage effects we find on high-tech manufacturing workers (Table 7). Third, Ruffner and Siegenthaler (2016) find that firms also experienced larger innovation rates, larger employment shares in R\&D, and more entry of new establishments as a consequence of CBW liberalization.

Our paper, on the other hand, goes much more in depth into the analysis of the labor market dynamics triggered by the opening of the border. First, it shows that CBW were highly educated and did not crowd out other immigrants, but increased total foreign-born employment, especially of highly-skilled. Second we show that they triggered dynamics through which highlyeducated local workers were more likely to become top managers and stay in the municipality, while internal mobility of Swiss workers was not affected much. Third our analysis suggests that, possibly because of a positive local job multiplier (as in Moretti (2010)) from CBW, the employment and wages in high-tech manufacturing and knowledge-intensive services was positively affected. What both studies suggest is the fact that the absorption of new CBW after 2004 took place via job and firm creation and increased productivity, innovation, and total employment. Our analysis also unveils a more detailed account of who gained and who lost from the opening of the border among Swiss workers. Older, highly-educated, male workers with longer tenure were the main beneficiaries, as they took managerial jobs in response to CBW inflow. Importantly, these positive effects may be connected to the fact that the new CBW were highly skilled, that the growth in their supply had a transition period (1999-2004), during which firms could prepare their adjustment. The fact that we document also some positive firm creation during the transition phase confirms this conjecture. Hence, in evaluating the impact of immigration policy changes and the consequences of the ensuing inflow of immigrants, this episode may be particularly useful. ${ }^{44}$

A second paper with important similarity to ours, especially for the type of policy considered, is Dustmann, Schönberg and Stuhler (2017). The authors analyze the effect of a temporary agreement allowing the free access of cross-border workers from the Czech Republic to Germany between 1991 and 1993. This agreement followed the fall of Communism in Eastern Europe, and increased the presence of Czech workers in the bordering German regions. Similarly to the Swiss case, the effect on labor supply was highly concentrated near the border because

\footnotetext{
${ }^{44}$ It is somewhat harder to reconcile our results with the initial policy report by Losa, Bigotta and Gonzales (2012) that looked at the employment and wage effects of removing barriers on CBW. That paper applied a simple difference-in-difference approach between border and non-border regions and it focused on the short run effects (2 years after the policy). Such an approach can incur significant noise and measurement error as we documented that the changes in CBW took a few years since 2004 and that only the municipalities closest to the border (rather than the whole border region) experienced a significant increase in their supply.
} 
of the commuting requirement. Yet, Dustmann, Schönberg and Stuhler (2017) find that this inflow was associated with a large decline in the employment of old, unskilled Germans and a larger decline in wages of younger workers. The authors explain these differences with different degrees of rigidity of wages and elasticity of supply of different age groups. Our findings are particularly interesting in light of these results. However, it must be born in mind that there are three main differences between the German set-up and the Swiss case. First, the Czech inflow was mainly composed of less-educated workers hired in relatively manual-intensive occupations. Second, it was unexpected and not planned years in advance. Third, it was temporary, and perceived as such, and it was reversed in 1993. Each of these features may have reduced the response margin of native workers and firms, limiting the ability to absorb the new workers and hence these differences may contribute to explain the different labor market effects on natives: negative in the case of Dustmann, Schönberg and Stuhler (2017), and positive in our case. Dustmann, Schönberg and Stuhler (2017) also discuss the main channels of adjustment of native employment, which seems to be a reduction of other natives moving to those regions. This seems plausible because the region near the border with the Czech Republic, due to the turmoil created by the end of Communism, may have experienced more economic uncertainty and less growth than other regions around 1991-1992. The Swiss experiment, instead, took place around 2004, a period in which the countries near the border were not experiencing significant economic transitions. Hence it may be a cleaner case to isolate the effect of a permanent immigration reform on local labor markets, avoiding other economic spillover effects from across the border. Also the high skills of immigrants and the different horizon of the policy may be crucial to explain our positive results on native wages. More generally, however, we cannot make a strong statement about which feature of the Swiss set-up generated the difference for the effect on outcomes we observe vis-à-vis the German-Czech set-up in the early 1990s.

\section{Conclusion}

In this paper, we analyze the effect of liberalization of labor market access for cross-border workers, implemented in Switzerland between 1999 and 2007, on the labor supply of foreign workers and on native labor market outcomes. We adopt a difference-in-difference approach and we exploit the fact that the availability of cross-border workers strongly depended on the commuting time from the national border, as these workers resided abroad and commuted to work in Switzerland. After showing that the introduction of free labor market access for these workers in 2004 produced a progressive and significant increase in their employment in 
municipalities within $0-20$ minutes of travel time from the border, but very little effect beyond 30 minutes from the border, we analyze their impact on labor market outcomes of natives. We find that, in the aggregate, natives in municipalities within the $0-20$ minute range from the border did not experience any differential change in average log wages, log employment, or $\log$ hours after the liberalization relative to natives in similar municipalities farther away from the border. However, this insignificant post-liberalization change in averages masks a positive and significant change in the wages of highly-educated natives. This effect is the strongest and most robust estimate in the paper. We also find a positive but less robust and only marginally significant positive change on hours worked by less-educated natives in the region near the border after liberalization. To better understand these results, we analyze several margins and channels of adjustment for native workers that may explain the positive wage change for highly-educated natives, which is not consistent with a increase in supply in the canonical labor market model.

We rule out internal migration as a significant adjustment mechanism, and provide suggestive evidence on three interesting mechanisms that seem to be at work in response to the higher supply of CBW. First, we find evidence that highly-educated natives, and particularly older and more senior workers, became more likely to take top management positions. Second we find positive productivity (wage) effects in the high-tech manufacturing sector and in skilled services, where the employment of skilled CBW increased the most. Third, we find more new firm creation in the border regions after Full Liberalization.

Overall, this suggests that the CBW produced positive effects on local, highly-educated workers, through both a complementarity and a productivity channel, by pushing some of them to managerial and high-pay occupations and by attracting capital and new firms in knowledgeintensive sectors. The variety of responses to immigration makes clear that a simple static, partial-effects model of fixed demand and change in supply does not work well in explaining the effect of immigration in this case. Rather, different types of complementarity, gains from specialization, and productivity effects are at work when firms and workers adapt. Most importantly, this paper is one of the few to directly analyze the labor market consequences of a permanent and complete labor market liberalization policy for some foreign workers in local labor markets. 


\section{References}

Abberger, Klaus, Yngve Abrahamsen, Thomas Bolli, Andreas Dibiasi, Peter Egger, Andres Frick, Michael Graff, Florian Hälg, David Iselin, Samad Sarferaz, Jörg Schläpfer, Michael Siegenthaler, Banu Simmons-Süer, Jan-Egbert Sturm and Filip Tarlea. 2015. "Der Bilaterale Weg - Eine ökonomische Bestandsaufnahme." KOF Studien 2015(58).

Autor, David H., Lawrence F. Katz and Melissa S. Kearney. 2008. "Trends in US Wage Inequality: Revising the Revisionists." The Review of Economics and Statistics 90(2):300-323.

Autor, David H and Mark G Duggan. 2003. "The Rise in the Disability Rolls and the Decline in Unemployment." The Quarterly Journal of Economics 118(1):157-205.

Bartik, Timothy J. 1991. "Who Benefits from State and Local Economic Development Policies?" Books from Upjohn Press .

Beerli, Andreas, Ronald Indergand and Johannes Kunz. 2017. The supply of foreign talent: How skill-biased technology drives the skill mix of immigrants Evidence from Switzerland 1990-2010. Technical report KOF Working Papers, 436.

BFS. 2010. "Bundesamat für Statistik, Schweizerische Lohnstrukturerhebung 1994 - 2010.".

Bigotta, Maurizio. 2013. Priority to Local Workers and its Consequences on Unemployment Duration. Technical report LIVES Working Papers.

Blanchard, Olivier Jean and Lawrence F Katz. 1992. "Regional Evolutions." Brookings Papers on Economic Activity 1992(1):1-75.

Blau, Francine D and Lawrence M Kahn. 2012. Immigration and the Distribution of Incomes. Technical report National Bureau of Economic Research, Working Paper No. 18515.

Bohn, Sarah, Magnus Lofstrom and Steven Raphael. 2014. "Did the 2007 Legal Arizona Workers Act reduce the state's unauthorized immigrant population?" Review of Economics and Statistics 96(2):258-269.

Borjas, George J. 2003. "The Labor Demand Curve Is Downward Sloping: Reexamining the Impact of Immigration on the Labor Market." The Quarterly Journal of Economics 118(4):13351374 .

Bühler, Stefan, Marco Helm and Michael Lechner. 2011. Trade Liberalization and Growth: Plant-Level Evidence from Switzerland. Technical report University of St. Gallen, School of Economics and Political Science.

Bundesrat. 1999. "Botschaft zur Genehmigung der sektoriellen Abkommen zwischen der Schweiz und der EG vom 23. Juni 1999." https://www.admin.ch/opc/de/federal-gazette/1999/ 6128.pdf.

Card, David and John DiNardo. 2000. "Do Immigrant Inflows Lead to Native Outflows?" American Economic Review 90(2):360-367.

Cattaneo, Cristina, Carlo V Fiorio and Giovanni Peri. 2015. "What Happens to the Careers of European Workers When Immigrants "Take Their Jobs"?" Journal of Human Resources 50(3):655-693.

Chassamboulli, Andri and Theodore Palivos. 2014. "A Search-Equilibrium Approach to the Effects of Immigration on Labor Market Outcomes." International Economic Review 55(1):111129 .

Dustmann, Christian, Uta Schönberg and Jan Stuhler. 2017. "Labor Supply Shocks, Native Wages, and the Adjustment of Local Employment." The Quarterly Journal of Economics 132(1):435-483. 
Economist. 2016. "The parable of Ticino. The harsh lessons from Switzerland for Brexiteers." http://www.economist.com/news/europe/ 21707550-harsh-lessons-switzerland-brexiteers-parable-ticino.

EDA. 2015. Personenfreizügigkeit. Technical report Eidgenössiches Department für ausswärtige Angelgegenheiten.

Favre, Sandro, Rafael Lalive and Josef Zweimüller. 2013. Verdrängungseffekte des Freizügigkeitsabkommens Schweiz-EU auf dem Schweizer Arbeitsmarkt. Technical report Schlussbericht zuhanden von Staatssekretariat für Wirtschaft SECO.

Foged, Mette and Giovanni Peri. 2016. "Immigrants' Effect on Native Workers: New Analysis on Longitudinal Data." American Economic Journal: Applied Economics 8(2):1-34.

Glitz, Albrecht. 2012. "The Labor Market Impact of Immigration: A Quasi-Experiment Exploiting Immigrant Location Rules in Germany." Journal of Labor Economics 30(1):175-213.

Goldin, Claudia and Lawrence Katz. 2008. The Race Between Education and Technology. Belknap Press for Harvard University Press.

Henneberger, Fred and Alexandre Ziegler. 2011. Evaluation der Wirksamkeit der ankierenden Massnahmen zur Personenfreizu gigkeit: Teil 2: Empirische U berpru fung des Auftretens von Lohndruck aufgrund des Immigrationsdrucks aus den EU17/EFTA-Mitgliedstaaten. Technical report Diskussionspapiere des Forschungsinstituts für Arbeit und Arbeitsrecht an der Universität St. Gallen No. 125.

Hong, Gihoon and John McLaren. 2015. Are Immigrants a Shot in the Arm for the Local Economy? Technical report National Bureau of Economic Research, Working Paper 21123.

Katz, Lawrence F and Kevin M Murphy. 1992. "Changes in Relative Wages, 1963-1987: Supply and Demand Factors." The Quarterly Journal of Economics 107(1):35-78.

Kerr, William R and William F Lincoln. 2010. "The Supply Side of Innovation: H-1B Visa Reforms and US Ethnic Invention." Journal of Labor Economics 28(3):473-508.

Lafortune, Jeanne, José Tessada and Ethan Lewis. 2015. People and Machines: A Look at the Evolving Relationship Between Capital and Skill In Manufacturing 1860-1930 Using Immigration Shocks. Technical report National Bureau of Economic Research, Working Paper 21435 .

Lewis, Ethan and Giovanni Peri. 2014. Immigration and the Economy of Cities and Regions. Technical report National Bureau of Economic Research, Working Paper 20428.

Longhi, Simonetta, Peter Nijkamp and Jacques Poot. 2005. "A Meta-Analytic Assessment of the Effect of Immigration on Wages." Journal of Economic Surveys 19(3):451-477.

Losa, Fabio B., Maurizio Bigotta and Oscar Gonzales. 2012. La Libre Circulation: Joies ou Douleurs? Technical report Analisi dell'Ufficio di statistica del Cantone Ticino.

Mayda, Anna Maria. 2010. "International Migration: A Panel Data Analysis of the Determinants of Bilateral Flows." Journal of Population Economics 23(4):1249-1274.

Moretti, Enrico. 2004. "Estimating the Social Return to Higher Education: Evidence from Longitudinal and Repeated Cross-Sectional Data." Journal of Econometrics 121(1):175-212.

Moretti, Enrico. 2010. "Local Multipliers." The American Economic Review, Papers and Proceedings 100(2):1-7.

Neal, Derek. 1995. "Industry-Specific Human Capital: Evidence from Displaced Workers." Journal of labor Economics 13(4):653-677. 
Neue Zürcher Zeitung. 1999. "Sondersession der eidgenössischen Räte: Chancenplus für die bilateralen Abkommen. Risikominderung im Ständerat beim Personenverkehr." September 2, Zurich.

Ortega, Francesc and Giovanni Peri. 2014. "Openness and Income: The Roles of Trade and Migration." Journal of International Economics 92(2):231-251.

Ottaviano, Gianmarco IP and Giovanni Peri. 2012. "Rethinking the Effect of Immigration on Wages." Journal of the European Economic Association 10(1):152-197.

Peri, Giovanni. 2012. "The Effect of Immigration on Productivity: Evidence from US States." Review of Economics and Statistics 94(1):348-358.

Peri, Giovanni and Chad Sparber. 2011a. "Assessing Inherent Model Bias: An Application to Native Displacement in Response to Immigration." Journal of Urban Economics 69(1):82-91.

Peri, Giovanni and Chad Sparber. 2011b. "Highly Educated Immigrants and Native Occupational Choice." Industrial Relations: a journal of economy and society 50(3):385-411.

Peri, Giovanni, Kevin Shih and Chad Sparber. 2015a. Foreign and Native Skilled Workers: What Can We Learn from H-1B Lotteries? Technical Report Working Paper No. 21175 National Bureau of Economic Research.

Peri, Giovanni, Kevin Shih and Chad Sparber. 2015b. "STEM workers, H-1B visas, and productivity in US cities." Journal of Labor Economics 33(S1 Part 2):S225-S255.

Rogerson, Richard and Robert Shimer. 2011. Search in Macroeconomic Models of the Labor Market. In Handbook of Labor Economics, ed. David Card and Orley Ashenfelter. Vol. 4A Elsevier pp. 619-700.

Ruffner, Jan and Michael Siegenthaler. 2016. "From Labor to Cash Flow? The Impact of Abolishing All Immigration Restrictions for EU Workers on Swiss Firms." Mimeo.

Saiz, Albert. 2003. "Room in the Kitchen for the Melting Pot: Immigration and Rental Prices." Review of Economics and Statistics 85(3):502-521.

Schmidheiny, Kurt and Michaela Slotwinski. 2015. Behavioral Responses to Local Tax Rates: Quasi-Experimental Evidence from a Foreigners Tax Scheme in Switzerland. Technical report CESifo Working Paper No. 5518.

SSK. 2009. Die Besteuerung an der Quelle. Technical report Schweizer Steuerkonferenz - Vereinigung der schweizerischen Steuerbehörden.

Swiss Federal Statistical Office. 2015. "Grenzgänger/innen nach Wohn- und Arbeitsort (innerhalb oder ausserhalb der Schweiz), nach Nationalität. Durchschnitte über 3 Jahre." https://www.bfs.admin.ch/bfs/de/home/statistiken/arbeit-erwerb/ erhebungen/ggs . assetdetail.315072.html. 
Figure 1: Municipalities in the border region (gray) and in the non-border region (white)

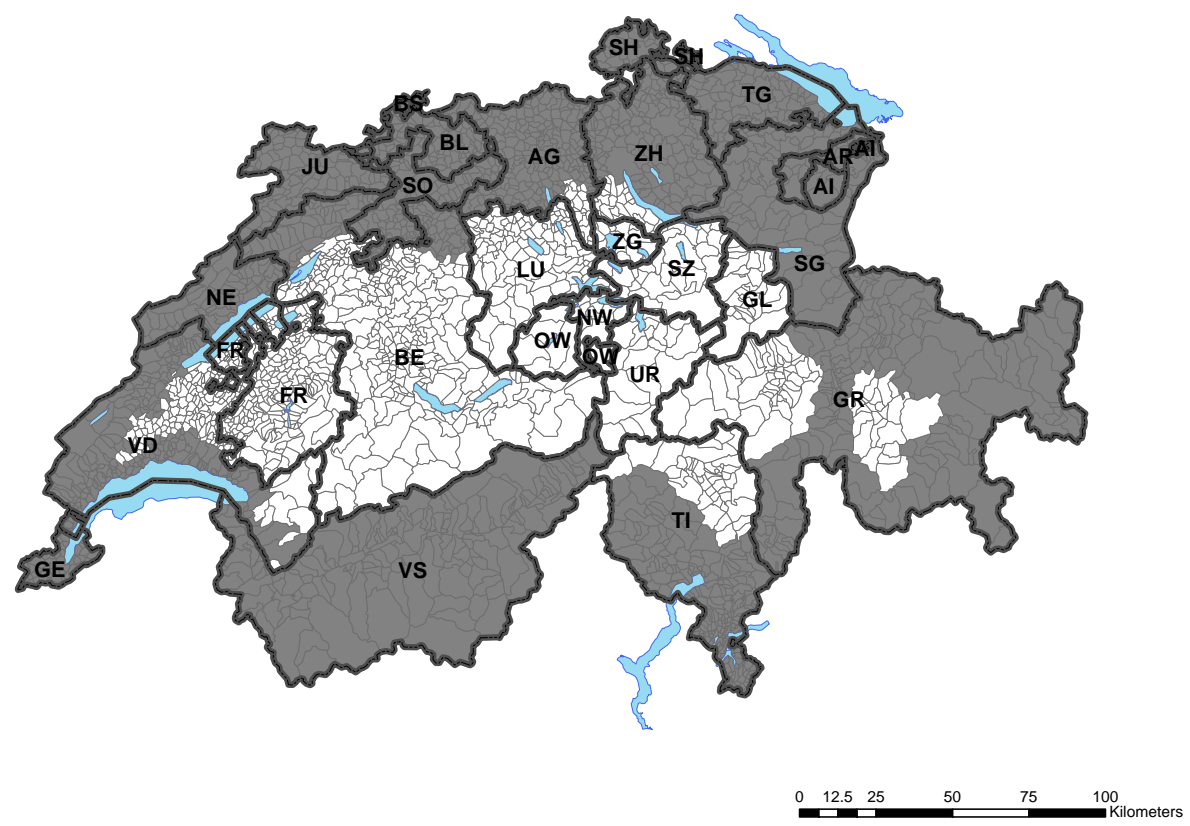

Notes: Municipalities in the border region are indicated in gray and those in the non-border region in white. The black lines and letters denote cantonal borders and abbreviations, respectively. Note that border regions do not overlap completely with cantonal borders. 
Table 1: Characteristics of natives and cross-border workers in the border region, 1998 and 2010

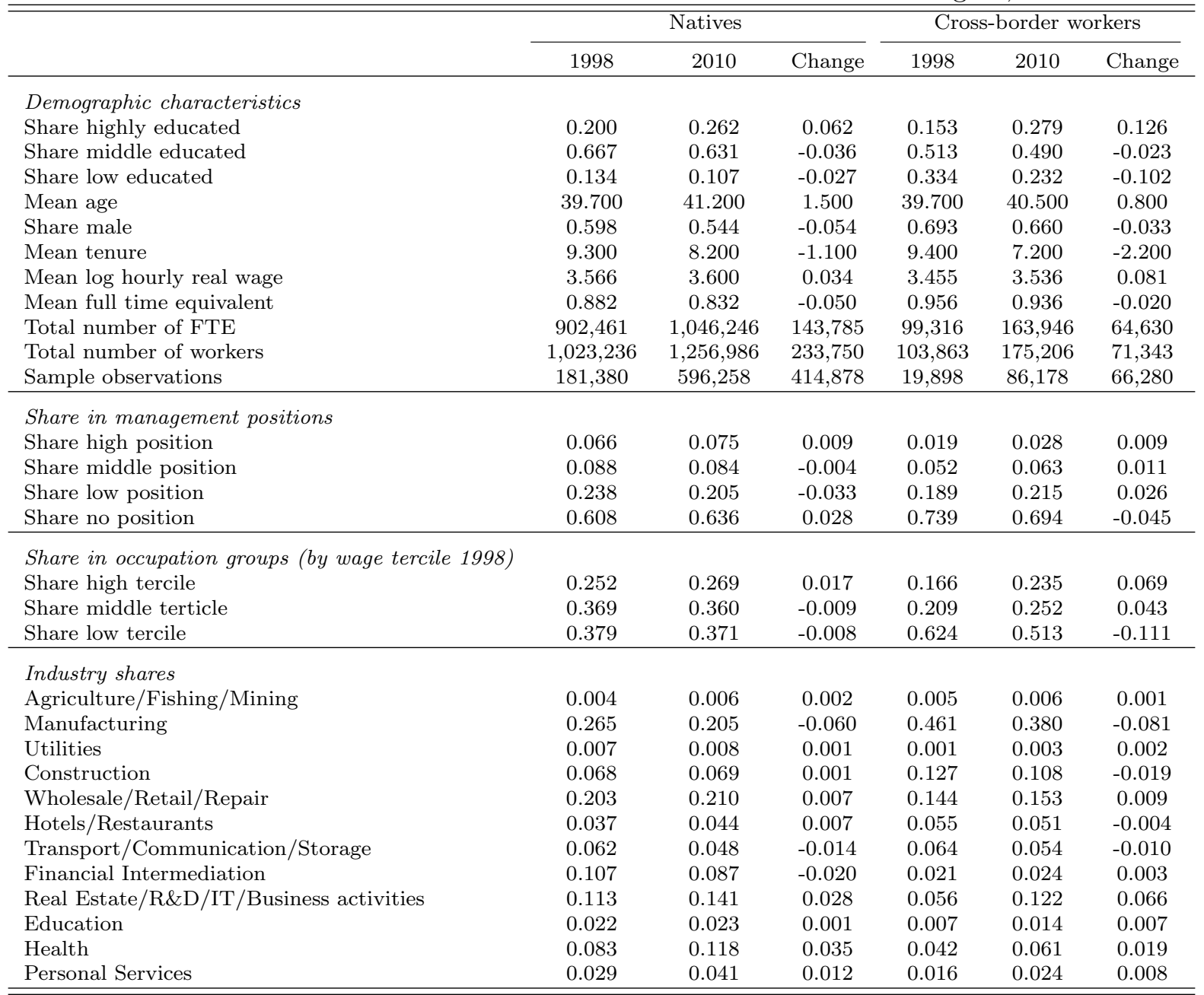

$\overline{\text { Notes: Occupations are categorized into high, middle, and low-paying occupations according to their average wage in } 1998 .}$ SESS data. 
Figure 2: Employment share of cross-border workers in distance bins

A. Share of cross-border workers on total employment 1998

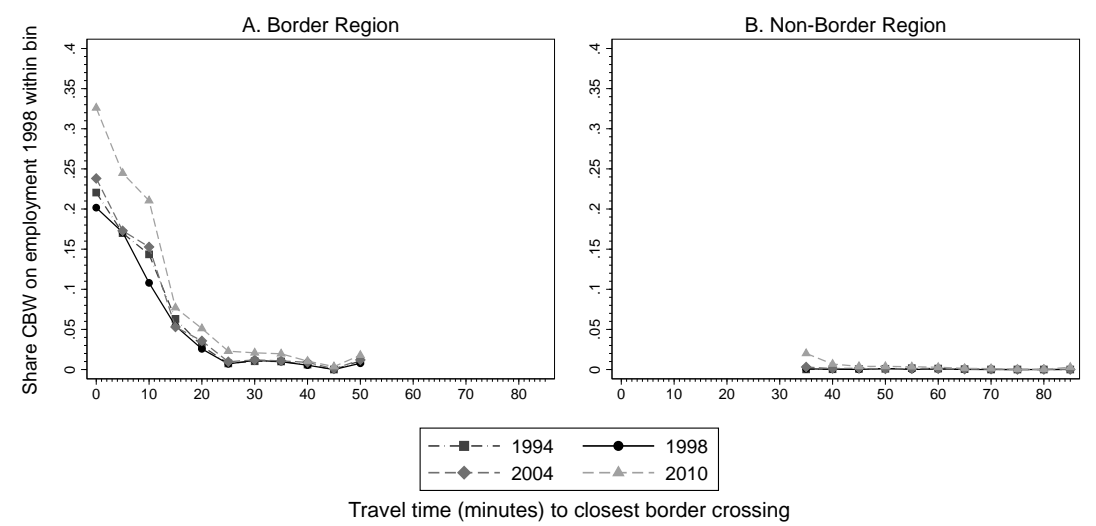

B. Smoothed change in share of cross-border workers on total employment 1998

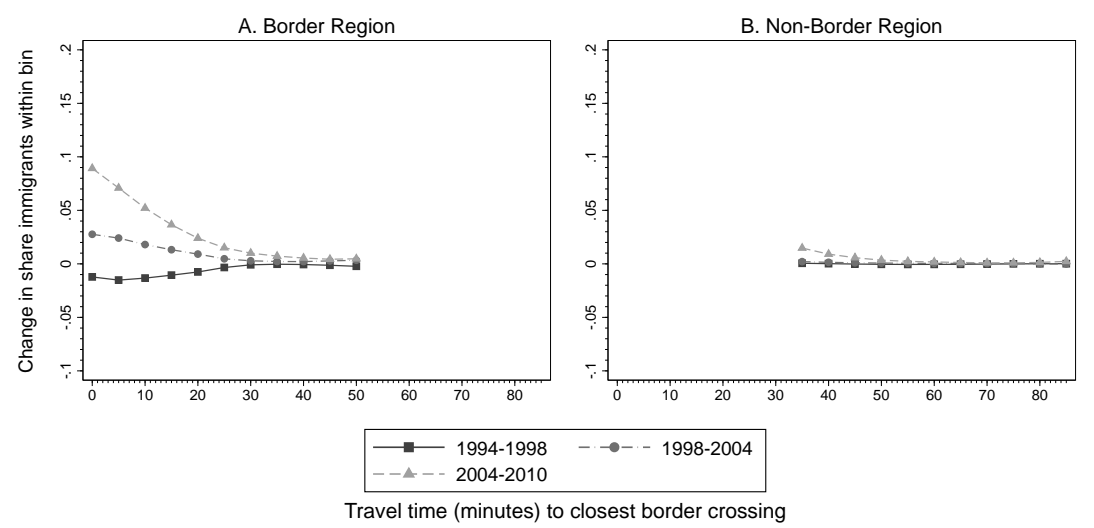

Notes: The figure plots the share of cross-border workers on total employment in 1998 in Panel A and the change between those shares in Panel B, separately for the border region and the non-border region. Municipalities are grouped into bins of 5 minutes according to their travel time by car to the next border crossing. Bins with a small number of total workers are omitted, i.e. those with travel time above 50 minutes in the border region and those between 13 and 35 minutes and above 85 minutes in the non-border region. The change in cross-border worker in the lower panel B is smoothed using a local polynomial with bandwidth 10 travel minutes. SESS data. 
Table 2: Cross Border Workers and Policy-Distance Interactions

Dependent variable: Share of cross-border workers and total foreign-born on total employment 1998

\begin{tabular}{|c|c|c|c|c|c|c|c|c|}
\hline & \multicolumn{7}{|c|}{ \# cross-border workers by education group } & \multirow{3}{*}{$\begin{array}{c}\begin{array}{c}\text { \# total } \\
\text { foreign-born }\end{array} \\
(8)\end{array}$} \\
\hline & \multicolumn{4}{|c|}{ all } & \multirow{2}{*}{$\frac{\text { high }}{(5)}$} & \multirow{2}{*}{$\frac{\text { middle }}{(6)}$} & \multirow{2}{*}{$\begin{array}{c}\text { low } \\
(7)\end{array}$} & \\
\hline & (1) & $(2)$ & $(3)$ & (4) & & & & \\
\hline Transition $_{t} \cdot I\left(\right.$ dist $\left._{m} \leq 10\right)$ & $\begin{array}{c}0.004 \\
(0.007)\end{array}$ & $\begin{array}{l}-0.003 \\
(0.008)\end{array}$ & $\begin{array}{l}-0.004 \\
(0.007)\end{array}$ & $\begin{array}{c}0.001 \\
(0.010)\end{array}$ & $\begin{array}{c}0.005 \\
(0.002)^{* *}\end{array}$ & $\begin{array}{c}0.009 \\
(0.003)^{* * *}\end{array}$ & $\begin{array}{c}-0.017 \\
(0.004)^{* * *}\end{array}$ & $\begin{array}{c}0.001 \\
(0.008)\end{array}$ \\
\hline Transition $_{t} \cdot I\left(10<\right.$ dist $\left._{m} \leq 20\right)$ & $\begin{array}{c}0.009 \\
(0.007)\end{array}$ & $\begin{array}{c}0.012 \\
(0.008)\end{array}$ & $\begin{array}{c}0.009 \\
(0.008)\end{array}$ & & $\begin{array}{c}0.006 \\
(0.002)^{* *}\end{array}$ & $\begin{array}{c}0.009 \\
(0.005)^{*}\end{array}$ & $\begin{array}{l}-0.003 \\
(0.003)\end{array}$ & $\begin{array}{l}-0.000 \\
(0.011)\end{array}$ \\
\hline Transition $_{t} \cdot I\left(20<\right.$ dist $\left._{m} \leq 30\right)$ & $\begin{array}{c}0.002 \\
(0.002)\end{array}$ & $\begin{array}{c}0.008 \\
(0.004)^{* *}\end{array}$ & $\begin{array}{c}0.006 \\
(0.003)^{* *}\end{array}$ & & $\begin{array}{c}0.003 \\
(0.001)^{* *}\end{array}$ & $\begin{array}{c}0.003 \\
(0.002)^{*}\end{array}$ & $\begin{array}{c}0.002 \\
(0.002)\end{array}$ & $\begin{array}{c}0.017 \\
(0.007)^{* *}\end{array}$ \\
\hline$F R E E_{t} \cdot I\left(\right.$ dist $\left._{m} \leq 10\right)$ & $\begin{array}{c}0.049 \\
(0.017)^{* * *}\end{array}$ & $\begin{array}{c}0.034 \\
(0.014)^{* *}\end{array}$ & $\begin{array}{c}0.033 \\
(0.014)^{* *}\end{array}$ & $\begin{array}{c}0.039 \\
(0.016)^{* *}\end{array}$ & $\begin{array}{c}0.028 \\
(0.005)^{* * *}\end{array}$ & $\begin{array}{c}0.022 \\
(0.007)^{* * *}\end{array}$ & $\begin{array}{c}-0.015 \\
(0.004)^{* * *}\end{array}$ & $\begin{array}{c}0.049 \\
(0.013)^{* * *}\end{array}$ \\
\hline$F R E E_{t} \cdot I\left(10<\right.$ dist $\left._{m} \leq 20\right)$ & $\begin{array}{c}0.034 \\
(0.016)^{* *}\end{array}$ & $\begin{array}{c}0.040 \\
(0.015)^{* * *}\end{array}$ & $\begin{array}{c}0.037 \\
(0.014)^{* *}\end{array}$ & & $\begin{array}{c}0.015 \\
(0.006)^{* *}\end{array}$ & $\begin{array}{c}0.024 \\
(0.009)^{* *}\end{array}$ & $\begin{array}{c}0.001 \\
(0.004)\end{array}$ & $\begin{array}{c}0.042 \\
(0.020)^{* *}\end{array}$ \\
\hline$F R E E_{t} \cdot I\left(20<\right.$ dist $\left._{m} \leq 30\right)$ & $\begin{array}{c}0.004 \\
(0.003) \\
\end{array}$ & $\begin{array}{c}0.016 \\
(0.006)^{* * *} \\
\end{array}$ & $\begin{array}{c}0.013 \\
(0.005)^{* *}\end{array}$ & & $\begin{array}{c}0.005 \\
(0.002)^{* *} \\
\end{array}$ & $\begin{array}{c}0.009 \\
(0.003)^{* * *}\end{array}$ & $\begin{array}{c}0.002 \\
(0.001) \\
\end{array}$ & $\begin{array}{c}0.036 \\
(0.009)^{* * *} \\
\end{array}$ \\
\hline R-squared & 0.544 & 0.545 & 0.553 & 0.539 & 0.492 & 0.522 & 0.431 & 0.509 \\
\hline Observations & 10053 & 10053 & 14859 & 3753 & 10053 & 10053 & 10053 & 10053 \\
\hline $\begin{array}{l}\text { Including NBR Sample } \\
\text { Matched control municipalities }\end{array}$ & & & $\sqrt{ }$ & $\sqrt{ }$ & & & & \\
\hline $\begin{array}{l}\text { Year/Area fixed effects } \\
\text { Bartik } \\
\text { Nuts II trend }\end{array}$ & $\begin{array}{l}\sqrt{ } \\
\sqrt{ }\end{array}$ & $\begin{array}{l}\sqrt{ } \\
\sqrt{ } \\
\sqrt{ }\end{array}$ & $\begin{array}{l}\sqrt{ } \\
\sqrt{ } \\
\sqrt{ }\end{array}$ & $\begin{array}{l}\sqrt{ } \\
\sqrt{ } \\
\sqrt{ }\end{array}$ & $\begin{array}{l}\sqrt{ } \\
\sqrt{ } \\
\sqrt{ }\end{array}$ & $\begin{array}{l}\sqrt{ } \\
\sqrt{ } \\
\sqrt{ }\end{array}$ & $\begin{array}{l}\sqrt{ } \\
\sqrt{ } \\
\sqrt{ }\end{array}$ & $\begin{array}{l}\sqrt{ } \\
\sqrt{ } \\
\sqrt{ }\end{array}$ \\
\hline
\end{tabular}

Notes: ${ }^{* *},{ }^{* *},{ }^{*}$, denote statistical significance at the $1 \%, 5 \%$ and $10 \%$ level, respectively. Robust standard errors, clustered by commuting zone, are given in parentheses. Transition $t$ is one for the period between 2000 and 2003 , whereas $F R E E_{t}$ is one from year 2004 onward. $\left(\right.$ dist $\left._{m} \leq x\right)$ and $\left(y<\right.$ dist $\left._{m} \leq z\right)$ indicate whether a municipality is located less than $x$ travel minutes or between $y$ and $z$ travel minutes from the next border crossing, respectively. Regressions are weighted using the total workforce in 1998 in a cell. SESS data. 
Figure 3: Event analysis of effect of free movement policy on share of immigrants on total employment
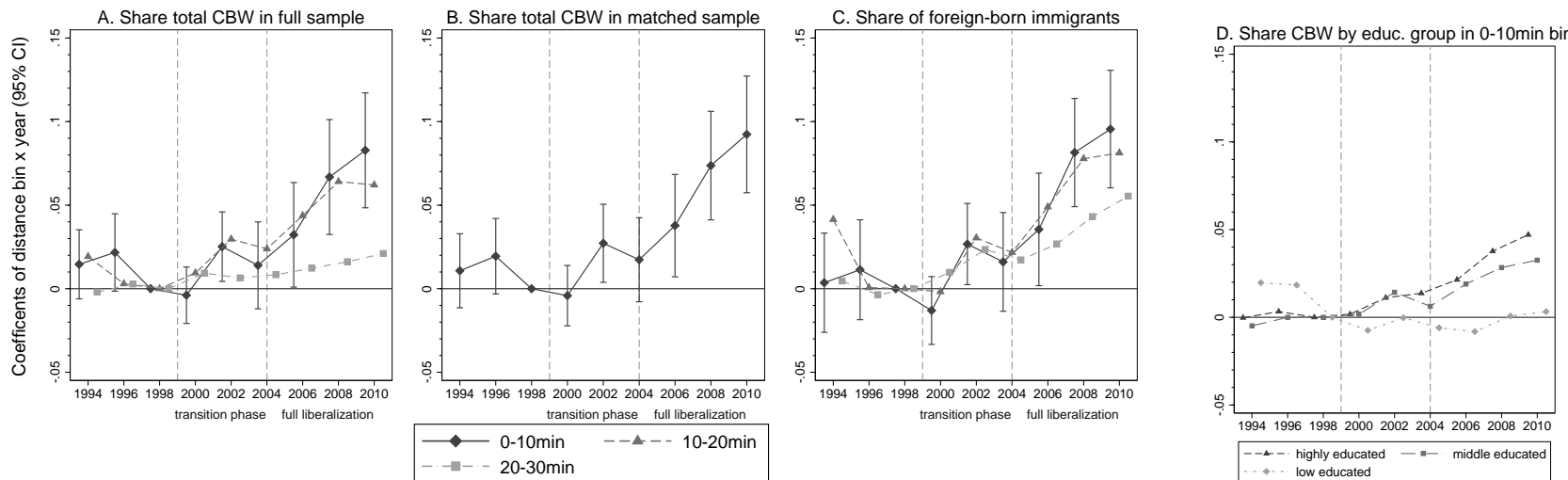

Notes: The figure plots the coefficients and the $95 \%$ confidence interval for the $0-10 \mathrm{~min}$ distance bin of a regression based on equation (3) with the share of cross-border workers on total employment in 1998 as dependent variable. Regressions are weighted using the total workforce in 1998 in a cell and include NUTS II trends and the Bartik measure. Only municipalities in the border region are included in panel A, C and D. In panel B each municipality in the 0-10 minute bin is matched to a control municipality in the border region 30 minutes or more from the border or in the non-border region as described in section 4.1. Standard errors are clustered on the CZ level. SESS data. 
Table 3a: Effect of free movement policy on wage and employment of natives

\begin{tabular}{|c|c|c|c|c|c|c|}
\hline \multirow[t]{2}{*}{ Dependent variable } & \multicolumn{2}{|c|}{ Mean log hourly wages } & \multicolumn{2}{|c|}{ Log \# workers } & \multicolumn{2}{|c|}{ Log \# hours } \\
\hline & $(1)$ & $(2)$ & (3) & $(4)$ & $(5)$ & $(6)$ \\
\hline Transition $_{t} \cdot I\left(\right.$ dist $\left._{m} \leq 10\right)$ & $\begin{array}{c}0.004 \\
(0.010)\end{array}$ & $\begin{array}{c}0.000 \\
(0.009)\end{array}$ & $\begin{array}{l}-0.035 \\
(0.050)\end{array}$ & $\begin{array}{l}-0.050 \\
(0.051)\end{array}$ & $\begin{array}{l}-0.026 \\
(0.056)\end{array}$ & $\begin{array}{l}-0.046 \\
(0.056)\end{array}$ \\
\hline Transition $_{t} \cdot I\left(10<\right.$ dist $\left._{m} \leq 20\right)$ & $\begin{array}{c}0.018 \\
(0.010)^{*}\end{array}$ & $\begin{array}{c}0.014 \\
(0.009)\end{array}$ & $\begin{array}{c}0.076 \\
(0.064)\end{array}$ & $\begin{array}{c}0.060 \\
(0.061)\end{array}$ & $\begin{array}{c}0.082 \\
(0.060)\end{array}$ & $\begin{array}{c}0.060 \\
(0.057)\end{array}$ \\
\hline Transition $_{t} \cdot I\left(20<\right.$ dist $\left._{m} \leq 30\right)$ & $\begin{array}{c}0.011 \\
(0.008)\end{array}$ & $\begin{array}{l}0.008 \\
(0.007)\end{array}$ & $\begin{array}{l}0.005 \\
(0.048)\end{array}$ & $\begin{array}{l}-0.011 \\
(0.046)\end{array}$ & $\begin{array}{c}0.014 \\
(0.050)\end{array}$ & $\begin{array}{l}-0.007 \\
(0.047)\end{array}$ \\
\hline$F R E E_{t} \cdot I\left(\right.$ dist $\left._{m} \leq 10\right)$ & $\begin{array}{l}-0.018 \\
(0.027)\end{array}$ & $\begin{array}{l}-0.018 \\
(0.027)\end{array}$ & $\begin{array}{c}0.030 \\
(0.049)\end{array}$ & $\begin{array}{c}0.019 \\
(0.047)\end{array}$ & $\begin{array}{c}0.023 \\
(0.041)\end{array}$ & $\begin{array}{c}0.010 \\
(0.040)\end{array}$ \\
\hline$F R E E_{t} \cdot I\left(10<\right.$ dist $\left._{m} \leq 20\right)$ & $\begin{array}{c}0.011 \\
(0.008)\end{array}$ & $\begin{array}{c}0.012 \\
(0.008)\end{array}$ & $\begin{array}{c}0.002 \\
(0.050)\end{array}$ & $\begin{array}{l}-0.009 \\
(0.052)\end{array}$ & $\begin{array}{l}-0.000 \\
(0.049)\end{array}$ & $\begin{array}{l}-0.013 \\
(0.051)\end{array}$ \\
\hline$F R E E_{t} \cdot I\left(20<\right.$ dist $\left._{m} \leq 30\right)$ & $\begin{array}{c}0.006 \\
(0.007)\end{array}$ & $\begin{array}{c}0.007 \\
(0.007)\end{array}$ & $\begin{array}{l}0.026 \\
(0.036)\end{array}$ & $\begin{array}{c}0.013 \\
(0.034)\end{array}$ & $\begin{array}{c}0.031 \\
(0.037)\end{array}$ & $\begin{array}{c}0.016 \\
(0.035)\end{array}$ \\
\hline R-squared & 0.775 & 0.768 & 0.976 & 0.973 & 0.975 & 0.972 \\
\hline Observations & 11727 & 17616 & 11734 & 17626 & 11734 & 17626 \\
\hline Including NBR Sample & & $\sqrt{ }$ & & $\sqrt{ }$ & & $\sqrt{ }$ \\
\hline $\begin{array}{l}\text { Year/Area fixed effects } \\
\text { Bartik } \\
\text { Nuts II trend }\end{array}$ & $\begin{array}{l}\sqrt{ } \\
\sqrt{ } \\
\sqrt{ }\end{array}$ & $\begin{array}{l}\sqrt{ } \\
\sqrt{ } \\
\sqrt{ }\end{array}$ & $\begin{array}{l}\sqrt{ } \\
\sqrt{ } \\
\sqrt{ }\end{array}$ & $\begin{array}{l}\sqrt{ } \\
\sqrt{ } \\
\sqrt{ }\end{array}$ & $\begin{array}{l}\sqrt{ } \\
\sqrt{ } \\
\sqrt{ }\end{array}$ & $\begin{array}{l}\sqrt{ } \\
\sqrt{ } \\
\sqrt{ }\end{array}$ \\
\hline
\end{tabular}

Notes: ${ }^{* * *},{ }^{* *},{ }^{*}$, denote statistical significance at the $1 \%, 5 \%$ and $10 \%$ level, respectively. Robust standard errors, clustered by commuting zone, are given in parentheses. Transition $t$ is one for the period between 2000 and 2003, whereas $F R E E_{t}$ is one from year 2004 onward. (dist $\left.t_{m} \leq x\right)$ and $\left(y<\right.$ dist $\left._{m} \leq z\right)$ indicate whether a municipality is located less than $x$ travel minutes or between $y$ and $z$ travel minutes from the next border crossing, respectively. Regressions are weighted using the total number of natives in a cell. SESS data. 
Table 3b: Effect of free movement policy on wage and employment of natives by education group

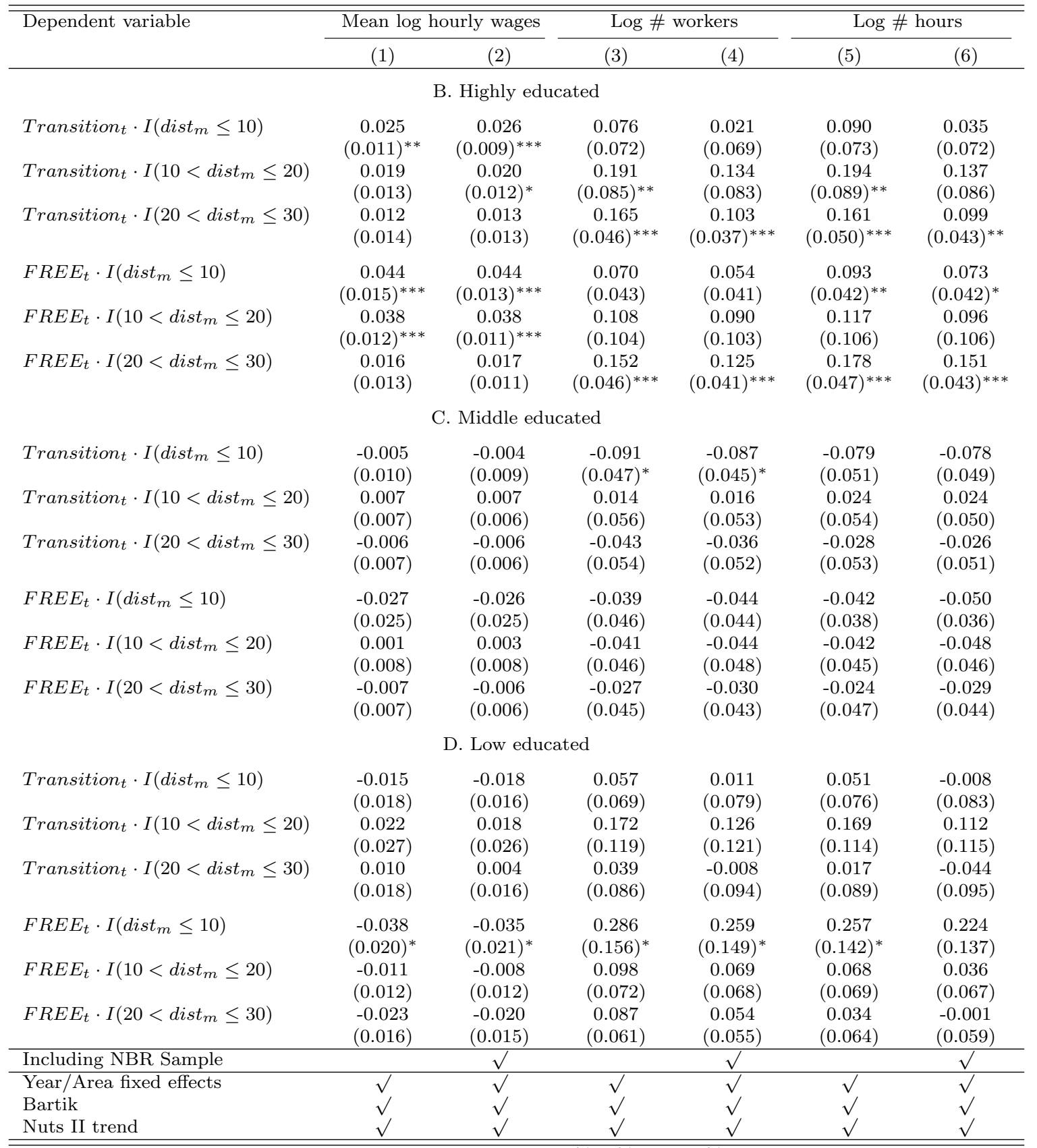

Notes: ${ }^{* * *},{ }^{* *},{ }^{*}$, denote statistical significance at the $1 \%, 5 \%$ and $10 \%$ level, respectively. Robust standard errors, clustered by commuting zone, are given in parentheses. Transition is one for the

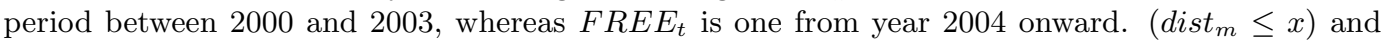
$\left(y<\right.$ dist $\left._{m} \leq z\right)$ indicate whether a municipality is located less than $x$ travel minutes or between $y$ and $z$ travel minutes from the next border crossing, respectively. Regressions are weighted using the total number of natives in a cell. SESS data. 
Figure 4: Event analysis of effect of free movement policy on wage of natives by education group
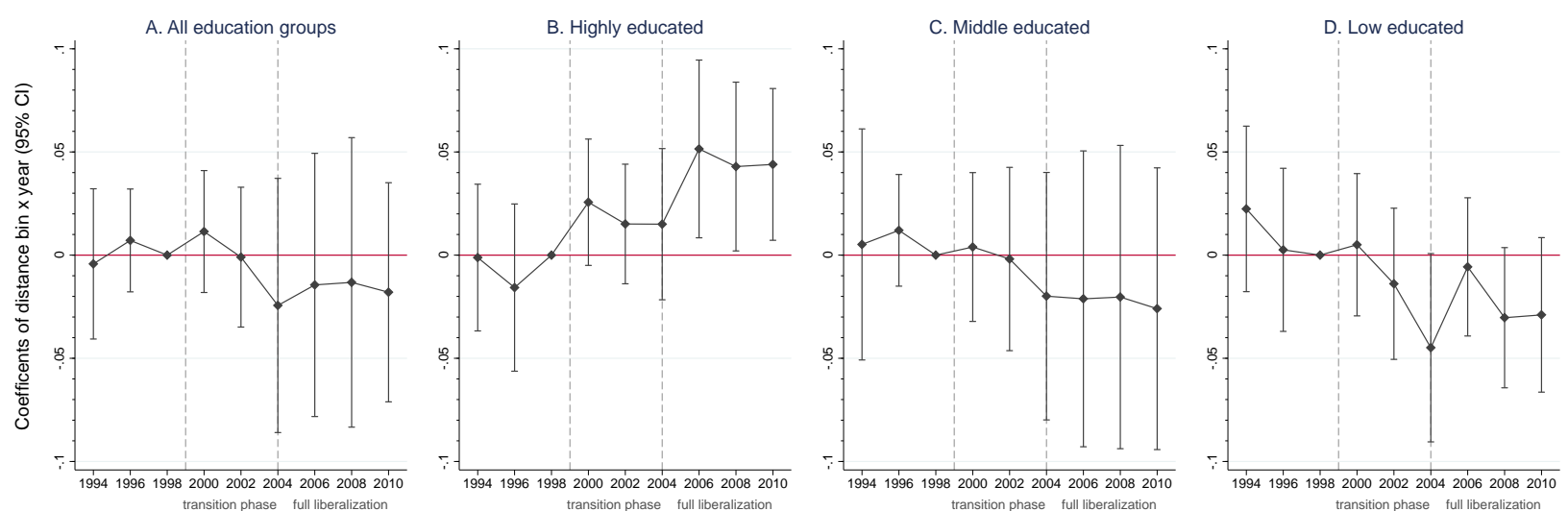

Notes: The figure plots the coefficients (and the $95 \%$ confidence interval for the 0-10min distance bin) of a regression based on equation (3) with the average log hourly wage of an education group of native workers as dependent variable. Regressions are weighted using the number of native in a cell and include NUTS II trends and the education specific Bartik measure. Standard errors are clustered on the CZ level. The sample includes only municipalities in the border region. SESS data.

Figure 5: Event analysis of effect of free movement policy on hours worked by natives by education group
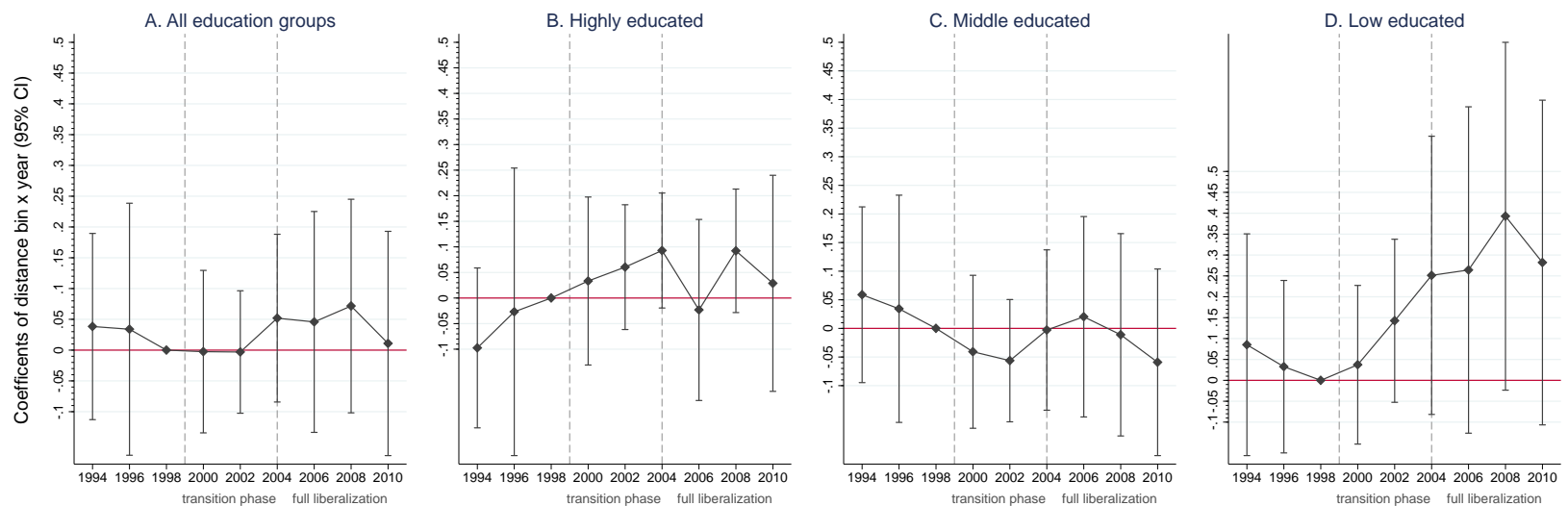

Notes: The figure plots the coefficients (and the $95 \%$ confidence interval for the 0-10min distance bin) of a regression based on equation (3) with the average log hourly wage of an education group of native workers as dependent variable. Regressions are weighted using the number of native in a cell and include NUTS II trends and the education specific Bartik measure. Standard errors are clustered on the CZ level. The sample includes only municipalities in the border region. SESS data. 
Table 4: Effect of free movement policy on inflow and outflow of local employment by natives

\begin{tabular}{|c|c|c|c|c|c|}
\hline \multirow{3}{*}{ Dependent Variable } & \multirow{3}{*}{$\frac{\text { Netflow }}{(1)}$} & \multicolumn{2}{|c|}{ Share inflow from } & \multicolumn{2}{|c|}{ Share outflow to } \\
\hline & & \multirow{2}{*}{$\begin{array}{c}B R \leq 30 \\
(2)\end{array}$} & \multirow{2}{*}{$\frac{B R>30}{(3)}$} & \multirow{2}{*}{$\frac{B R \leq 30}{(4)}$} & \multirow{2}{*}{$\begin{array}{c}B R>30 \\
(5)\end{array}$} \\
\hline & & & & & \\
\hline \multicolumn{6}{|c|}{ A. All education groups } \\
\hline$F R E E_{t} \cdot I\left(\right.$ dist $\left._{m} \leq 10\right)$ & $\begin{array}{l}-0.010 \\
(0.015)\end{array}$ & $\begin{array}{l}-0.008 \\
(0.007)\end{array}$ & $\begin{array}{c}0.002 \\
(0.004)\end{array}$ & $\begin{array}{c}0.002 \\
(0.011)\end{array}$ & $\begin{array}{c}0.003 \\
(0.005)\end{array}$ \\
\hline$F R E E_{t} \cdot I\left(10<\right.$ dist $\left._{m} \leq 20\right)$ & $\begin{array}{c}0.001 \\
(0.015)\end{array}$ & $\begin{array}{l}-0.001 \\
(0.011)\end{array}$ & $\begin{array}{l}-0.003 \\
(0.006)\end{array}$ & $\begin{array}{c}0.002 \\
(0.009)\end{array}$ & $\begin{array}{c}0.007 \\
(0.006)\end{array}$ \\
\hline$F R E E_{t} \cdot I\left(20<\right.$ dist $\left._{m} \leq 30\right)$ & $\begin{array}{c}0.002 \\
(0.012)\end{array}$ & $\begin{array}{l}-0.005 \\
(0.007)\end{array}$ & $\begin{array}{c}0.004 \\
(0.006)\end{array}$ & $\begin{array}{l}-0.001 \\
(0.008)\end{array}$ & $\begin{array}{c}0.001 \\
(0.005)\end{array}$ \\
\hline \multicolumn{6}{|c|}{ B. Highly educated } \\
\hline$F R E E_{t} \cdot I\left(\right.$ dist $\left._{m} \leq 10\right)$ & $\begin{array}{l}-0.011 \\
(0.026)\end{array}$ & $\begin{array}{l}-0.015 \\
(0.013)\end{array}$ & $\begin{array}{l}-0.007 \\
(0.007)\end{array}$ & $\begin{array}{l}-0.009 \\
(0.014)\end{array}$ & $\begin{array}{l}-0.006 \\
(0.006)\end{array}$ \\
\hline$F R E E_{t} \cdot I\left(10<\right.$ dist $\left._{m} \leq 20\right)$ & $\begin{array}{l}-0.000 \\
(0.030)\end{array}$ & $\begin{array}{l}-0.013 \\
(0.016)\end{array}$ & $\begin{array}{c}-0.031 \\
(0.012)^{* *}\end{array}$ & $\begin{array}{l}-0.014 \\
(0.017)\end{array}$ & $\begin{array}{c}-0.018 \\
(0.008)^{* *}\end{array}$ \\
\hline$F R E E_{t} \cdot I\left(20<\right.$ dist $\left._{m} \leq 30\right)$ & $\begin{array}{c}0.032 \\
(0.023)\end{array}$ & $\begin{array}{l}-0.009 \\
(0.013)\end{array}$ & $\begin{array}{l}-0.003 \\
(0.011)\end{array}$ & $\begin{array}{l}-0.021 \\
(0.013)\end{array}$ & $\begin{array}{l}-0.004 \\
(0.009)\end{array}$ \\
\hline \multicolumn{6}{|c|}{ C. Middle educated } \\
\hline$F R E E_{t} \cdot I\left(\right.$ dist $\left._{m} \leq 10\right)$ & $\begin{array}{l}-0.005 \\
(0.020)\end{array}$ & $\begin{array}{c}0.004 \\
(0.006)\end{array}$ & $\begin{array}{c}0.005 \\
(0.007)\end{array}$ & $\begin{array}{c}0.010 \\
(0.011)\end{array}$ & $\begin{array}{c}0.010 \\
(0.006)^{*}\end{array}$ \\
\hline$F R E E_{t} \cdot I\left(10<\right.$ dist $\left._{m} \leq 20\right)$ & $\begin{array}{l}-0.028 \\
(0.020)\end{array}$ & $\begin{array}{l}-0.003 \\
(0.012)\end{array}$ & $\begin{array}{c}0.004 \\
(0.008)\end{array}$ & $\begin{array}{c}0.011 \\
(0.009)\end{array}$ & $\begin{array}{c}0.022 \\
(0.007)^{* * *}\end{array}$ \\
\hline$F R E E_{t} \cdot I\left(20<\right.$ dist $\left._{m} \leq 30\right)$ & $\begin{array}{l}-0.017 \\
(0.020)\end{array}$ & $\begin{array}{l}-0.006 \\
(0.006)\end{array}$ & $\begin{array}{c}0.003 \\
(0.007)\end{array}$ & $\begin{array}{c}0.007 \\
(0.010)\end{array}$ & $\begin{array}{c}0.010 \\
(0.006)\end{array}$ \\
\hline \multicolumn{6}{|c|}{ D. Low educated } \\
\hline$F R E E_{t} \cdot I\left(\right.$ dist $\left._{m} \leq 10\right)$ & $\begin{array}{l}-0.030 \\
(0.039)\end{array}$ & $\begin{array}{l}-0.007 \\
(0.020)\end{array}$ & $\begin{array}{l}-0.009 \\
(0.013)\end{array}$ & $\begin{array}{c}0.025 \\
(0.036)\end{array}$ & $\begin{array}{c}-0.035 \\
(0.014)^{* *}\end{array}$ \\
\hline$F R E E_{t} \cdot I\left(10<\right.$ dist $\left._{m} \leq 20\right)$ & $\begin{array}{c}0.158 \\
(0.054)^{* * *}\end{array}$ & $\begin{array}{c}0.119 \\
(0.030)^{* * *}\end{array}$ & $\begin{array}{l}-0.009 \\
(0.011)\end{array}$ & $\begin{array}{l}-0.019 \\
(0.026)\end{array}$ & $\begin{array}{l}-0.039 \\
(0.024)\end{array}$ \\
\hline$F R E E_{t} \cdot I\left(20<\right.$ dist $\left._{m} \leq 30\right)$ & $\begin{array}{c}0.049 \\
(0.045) \\
\end{array}$ & $\begin{array}{c}0.040 \\
(0.013)^{* * *} \\
\end{array}$ & $\begin{array}{c}0.001 \\
(0.015) \\
\end{array}$ & $\begin{array}{l}-0.007 \\
(0.018) \\
\end{array}$ & $\begin{array}{c}-0.027 \\
(0.014)^{*}\end{array}$ \\
\hline Year/Area fixed effects & $\sqrt{ }$ & $\sqrt{ }$ & $\sqrt{ }$ & $\sqrt{ }$ & $\sqrt{ }$ \\
\hline Bartik & $\sqrt{ }$ & $\sqrt{ }$ & $\sqrt{ }$ & $\sqrt{ }$ & $\sqrt{ }$ \\
\hline Nuts II trend & $\sqrt{ }$ & $\sqrt{ }$ & $\sqrt{ }$ & $\sqrt{ }$ & $\sqrt{ }$ \\
\hline
\end{tabular}

Notes: ${ }^{* * *},{ }^{* *},{ }^{*}$, denote statistical significance at the $1 \%, 5 \%$ and $10 \%$ level, respectively. Robust standard errors, clustered by commuting zone, are given in parentheses. FREE $E_{t}$ is one from year 2004 onward. $\left(\right.$ dist $\left._{m} \leq x\right)$ and $\left(y<\right.$ dist $\left._{m} \leq z\right)$ indicate whether a municipality is located less than $x$ travel minutes or between $y$ and $z$ travel minutes from the next border crossing, respectively. Regressions are weighted using the total number of natives in a cell. The netflow is the sum of inflow minus outflows between two consecutive years. The inflows into employment in municipality $m$ is composed of inflows from other municipalities in the border region below 30 minutes driving time or above or from non-employment. The estimates for the latter category are omitted from the table for brevity. Outflows are computed similarly. See Section 6.1 and Online Appendix B for more details. SLFS data 1996-2008. 
Table 5: Effect of the free movement policy on share and number of natives in top tier management

\begin{tabular}{|c|c|c|c|c|}
\hline \multirow[t]{3}{*}{ Dependent variable } & \multicolumn{2}{|c|}{ Share board members } & \multicolumn{2}{|c|}{ Log (board members) } \\
\hline & & & \multirow{2}{*}{$\frac{\text { \# Workers }}{(3)}$} & \multirow{2}{*}{$\begin{array}{c}\text { \# Hours } \\
(4)\end{array}$} \\
\hline & (1) & $(2)$ & & \\
\hline \multicolumn{5}{|c|}{ A. All education groups } \\
\hline$F R E E_{t} \cdot I\left(\right.$ dist $\left._{m} \leq 10\right)$ & $\begin{array}{c}0.016 \\
(0.010)\end{array}$ & $\begin{array}{c}0.017 \\
(0.010)^{*}\end{array}$ & $\begin{array}{c}0.057 \\
(0.045)\end{array}$ & $\begin{array}{c}0.054 \\
(0.047)\end{array}$ \\
\hline$F R E E_{t} \cdot I\left(10<\right.$ dist $\left._{m} \leq 20\right)$ & $\begin{array}{c}0.030 \\
(0.011)^{* * *}\end{array}$ & $\begin{array}{c}0.028 \\
(0.010)^{* * *}\end{array}$ & $\begin{array}{c}0.172 \\
(0.075)^{* *}\end{array}$ & $\begin{array}{c}0.178 \\
(0.085)^{* *}\end{array}$ \\
\hline Mean Dep. Var. & 0.196 & 0.196 & & \\
\hline \multicolumn{5}{|c|}{ B. Highly educated } \\
\hline $\begin{array}{l}F R E E_{t} \cdot I\left(\text { dist }_{m} \leq 10\right) \\
F R E E_{t} \cdot I\left(10<\text { dist }_{m} \leq 20\right) \\
\text { Mean Dep. Var. }\end{array}$ & $\begin{array}{c}0.062 \\
(0.026)^{* *} \\
0.033 \\
(0.027) \\
0.326\end{array}$ & $\begin{array}{c}0.062 \\
(0.024)^{* *} \\
0.032 \\
(0.026) \\
0.326\end{array}$ & $\begin{array}{c}0.179 \\
(0.063)^{* * *} \\
0.118 \\
(0.101)\end{array}$ & $\begin{array}{c}0.151 \\
(0.066)^{* *} \\
0.133 \\
(0.105)\end{array}$ \\
\hline \multicolumn{5}{|c|}{ C. Middle educated } \\
\hline $\begin{array}{l}F R E E_{t} \cdot I\left(\text { dist }_{m} \leq 10\right) \\
F R E E_{t} \cdot I\left(10<\text { dist }_{m} \leq 20\right) \\
\text { Mean Dep. Var. }\end{array}$ & $\begin{array}{c}-0.002 \\
(0.011) \\
0.030 \\
(0.012)^{* *} \\
0.157\end{array}$ & $\begin{array}{c}-0.001 \\
(0.011) \\
0.026 \\
(0.011)^{* *} \\
0.157\end{array}$ & $\begin{array}{c}-0.099 \\
(0.069) \\
0.112 \\
(0.089)\end{array}$ & $\begin{array}{c}-0.095 \\
(0.080) \\
0.081 \\
(0.105)\end{array}$ \\
\hline \multicolumn{5}{|c|}{ D. Low educated } \\
\hline$F R E E_{t} \cdot I\left(\right.$ dist $\left._{m} \leq 10\right)$ & $\begin{array}{c}-0.034 \\
(0.020)^{*}\end{array}$ & $\begin{array}{l}-0.029 \\
(0.019)\end{array}$ & $\begin{array}{l}-0.037 \\
(0.127)\end{array}$ & $\begin{array}{l}-0.133 \\
(0.173)\end{array}$ \\
\hline$F R E E_{t} \cdot I\left(10<\right.$ dist $\left._{m} \leq 20\right)$ & $\begin{array}{c}0.035 \\
(0.030)\end{array}$ & $\begin{array}{c}0.039 \\
(0.030)\end{array}$ & $\begin{array}{l}-0.470 \\
(0.192)^{* *}\end{array}$ & $\begin{array}{l}-0.198 \\
(0.269)\end{array}$ \\
\hline Mean Dep. Var. & 0.080 & 0.080 & & \\
\hline Including NBR Sample & & $\sqrt{ }$ & & \\
\hline Year/Area fixed effects & $\sqrt{ }$ & $\sqrt{ }$ & $\sqrt{ }$ & $\sqrt{ }$ \\
\hline Bartik & $\sqrt{ }$ & $\sqrt{ }$ & $\sqrt{ }$ & $\sqrt{ }$ \\
\hline Nuts II trend & $\sqrt{ }$ & $\sqrt{ }$ & $\sqrt{ }$ & $\sqrt{ }$ \\
\hline
\end{tabular}

Notes: ${ }^{* * *},{ }^{* *},{ }^{*}$, denote statistical significance at the $1 \%, 5 \%$ and $10 \%$ level, respectively. Robust standard errors, clustered by commuting zone, are given in parentheses. $F R E E_{t}$ is one for municipalities in the border region after 2004 and in the non-border region after 2007. $\left(\right.$ dist $\left._{m} \leq x\right)$ and $\left(y<\right.$ dist $\left._{m} \leq z\right)$ indicate whether a municipality is located less than $x$ travel minutes or between $y$ and $z$ travel minutes from the next border crossing, respectively. Regressions are weighted using the total number of natives in a cell. SLFS data 1996-2010. 
Table 6: Effect of the free movement policy on wages of highly educated natives in different management ranks

Dependent variable: Average log hourly wages of highly educated natives in management ranks

\begin{tabular}{|c|c|c|c|c|}
\hline & \multirow{2}{*}{$\begin{array}{l}\text { All highly } \\
\text { educated }\end{array}$} & \multicolumn{2}{|c|}{ Wage by manag. rank } & \multirow{2}{*}{$\begin{array}{c}\text { constant manag } \\
\text { rank shares }\end{array}$} \\
\hline & & high and middle & low and no & \\
\hline & $(1)$ & $(2)$ & $(3)$ & $(4)$ \\
\hline$F R E E_{t} \cdot I\left(\right.$ dist $\left._{m} \leq 10\right)$ & $\begin{array}{c}0.033 \\
(0.011)^{* * *}\end{array}$ & $\begin{array}{c}0.036 \\
(0.011)^{* * *}\end{array}$ & $\begin{array}{c}0.022 \\
(0.009)^{* *}\end{array}$ & $\begin{array}{c}0.027 \\
(0.006)^{* * *}\end{array}$ \\
\hline$F R E E_{t} \cdot I\left(10<\right.$ dist $\left._{m} \leq 20\right)$ & $\begin{array}{c}0.029 \\
(0.010)^{* * *}\end{array}$ & $\begin{array}{c}0.027 \\
(0.012)^{* *}\end{array}$ & $\begin{array}{c}0.021 \\
(0.011)^{*}\end{array}$ & $\begin{array}{c}0.016 \\
(0.008)^{*}\end{array}$ \\
\hline $\begin{array}{l}\text { Year/Area fixed effects } \\
\text { Bartik } \\
\text { Nuts II trend }\end{array}$ & $\begin{array}{l}\sqrt{ } \\
\sqrt{ } \\
\sqrt{ }\end{array}$ & $\begin{array}{l}\sqrt{ } \\
\sqrt{ } \\
\sqrt{ }\end{array}$ & $\begin{array}{l}\sqrt{ } \\
\sqrt{ } \\
\sqrt{ }\end{array}$ & $\begin{array}{l}\sqrt{ } \\
\sqrt{ } \\
\sqrt{ }\end{array}$ \\
\hline
\end{tabular}

Notes: ${ }^{* * *},{ }^{* *},{ }^{*}$, denote statistical significance at the $1 \%, 5 \%$ and $10 \%$ level, respectively. Robust standard errors, clustered by commuting zone, are given in parentheses. $F R E E_{t}$ is one for municipalities in the border region after 2004 and in the non-border region after 2007. $\left(\right.$ dist $\left._{m} \leq x\right)$ and $\left(y<\right.$ dist $\left._{m} \leq z\right)$ indicate whether a municipality is located less than $x$ travel minutes or between $y$ and $z$ travel minutes from the next border crossing, respectively. Regressions are weighted using the total number of natives in a cell. SESS data. 
Table 7: Effect of the free movement policy on wage levels of natives in sector Dependent variable: Share CBW (panel A) mean log hourly wage of natives by edu. groups (panel B-E)

\begin{tabular}{lccccc}
\hline \hline Category of employment & \multicolumn{2}{c}{ Manufacturing } & & \multicolumn{2}{c}{ Services } \\
\cline { 2 - 3 } & $\frac{\text { High-tech }}{(1)}$ & $\frac{\text { Low-tech }}{(2)}$ & & $\begin{array}{c}\text { Knowl.- } \\
\text { intensive }\end{array}$ & $\begin{array}{c}\text { Not-Knowl. } \\
\text { intensive }\end{array}$ \\
\hline
\end{tabular}

A. Share of CBW on emloyment in 1998

$\begin{array}{lcccc}\text { FRE } E_{t} \cdot I\left(\text { dist }_{m} \leq 10\right) & 0.058 & -0.012 & 0.051 & 0.019 \\ & (0.028)^{* *} & (0.016) & (0.005)^{* * *} & (0.020) \\ F R E E_{t} \cdot I\left(10<\text { dist }_{m} \leq 20\right) & 0.044 & -0.007 & 0.039 & 0.019 \\ & (0.032) & (0.012) & (0.015)^{* *} & (0.014)\end{array}$

B. All education groups

$\begin{array}{lcccc}\text { FRE } E_{t} \cdot I\left(\text { dist }_{m} \leq 10\right) & 0.042 & 0.008 & 0.020 & -0.028 \\ & (0.013)^{* * *} & (0.010) & (0.014) & (0.024) \\ F R E E_{t} \cdot I\left(10<\text { dist }_{m} \leq 20\right) & -0.005 & -0.016 & 0.020 & -0.006 \\ & (0.015) & (0.009)^{*} & (0.011)^{*} & (0.014) \\ & \text { C. Highly educated } & & \\ F R E E_{t} \cdot I\left(\text { dist }_{m} \leq 10\right) & 0.010 & -0.017 & 0.057 & 0.019 \\ & (0.014) & (0.026) & (0.012)^{* * *} & (0.021) \\ F R E E_{t} \cdot I\left(10<\text { dist }_{m} \leq 20\right) & -0.000 & -0.036 & 0.059 & 0.018 \\ & (0.015) & (0.019)^{*} & (0.017)^{* * *} & (0.022)\end{array}$

D. Middle educated

$\begin{array}{lcccc}F R E E_{t} \cdot I\left(\text { dist }_{m} \leq 10\right) & 0.032 & 0.005 & 0.009 & -0.028 \\ & (0.012)^{* *} & (0.012) & (0.016) & (0.020) \\ F R E E_{t} \cdot I\left(10<\text { dist }_{m} \leq 20\right) & -0.004 & -0.012 & 0.011 & -0.009 \\ & (0.014) & (0.009) & (0.010) & (0.016)\end{array}$

E. Low educated

\begin{tabular}{lcccc}
$F R E E_{t} \cdot I\left(\right.$ dist $\left._{m} \leq 10\right)$ & 0.033 & 0.011 & -0.030 & -0.015 \\
& $(0.020)^{*}$ & $(0.012)$ & $(0.015)^{* *}$ & $(0.010)$ \\
$F R E E_{t} \cdot I\left(10<\right.$ dist $\left._{m} \leq 20\right)$ & -0.027 & -0.005 & -0.017 & -0.028 \\
& $(0.035)$ & $(0.014)$ & $(0.023)$ & $(0.013)^{* *}$ \\
\hline \hline Year/Area fixed effects & $\sqrt{ }$ & $\sqrt{ }$ & $\sqrt{ }$ & $\sqrt{ }$ \\
Bartik & $\sqrt{ }$ & $\sqrt{ }$ & $\sqrt{ }$ & $\sqrt{ }$ \\
Nuts II trend & $\sqrt{ }$ & $\sqrt{ }$ & $\sqrt{ }$ & $\sqrt{ }$ \\
\hline \hline
\end{tabular}

Notes: ${ }^{* * *},{ }^{* *},{ }^{*}$, denote statistical significance at the $1 \%, 5 \%$ and $10 \%$ level, respectively. Robust standard errors, clustered by commuting zone, are given in parentheses. $F R E E_{t}$ is one for municipalities in the border region after 2004 and in the non-border region after 2007. $\left(\right.$ dist $\left._{m} \leq x\right)$ and $\left(y<\right.$ dist $\left._{m} \leq z\right)$ indicate whether a municipality is located less than $x$ travel minutes or between $y$ and $z$ travel minutes from the next border crossing, respectively. Regressions are weighted using the total number of natives in a cell. Columns (1)-(6) split group employment into mutually exclusive and exhaustive industries (omitting agriculture, mining and construction). High-tech manufacturing is NACE Rev 1.1 industries 24, 29, 30, 31, 32, 33, 34 and 35 excluding 35.1. Low-tech manufacturers are the remainder manufacturing categories. Knowledge-intensive services are NACE Rev 1.1 industries $61,62,64,65-67,70-74,80,85,92$. Columns (7)-(9) split group employment according to the size of the establishment. Large establishments have more than $250 \mathrm{FTEs}$, medium sized establishments have 50-250 FTEs and small establishments have 5-50 FTE. SESS data. 
Table 8: Effect of the free movement policy on hours worked by natives Dependent variable: Log total hours worked by natives by education group

\begin{tabular}{|c|c|c|c|c|}
\hline \multirow[t]{3}{*}{ Category of employment } & \multicolumn{2}{|c|}{ Manufacturing } & \multicolumn{2}{|c|}{ Services } \\
\hline & High-tech & Low-tech & $\begin{array}{l}\text { Knowl.- } \\
\text { intensive }\end{array}$ & $\begin{array}{l}\text { Not-Knowl. } \\
\text { intensive }\end{array}$ \\
\hline & $(1)$ & $(2)$ & $(3)$ & (4) \\
\hline \multicolumn{5}{|c|}{ B. All education groups } \\
\hline$F R E E_{t} \cdot I\left(\right.$ dist $\left._{m} \leq 10\right)$ & $\begin{array}{c}0.035 \\
(0.088)\end{array}$ & $\begin{array}{l}-0.032 \\
(0.073)\end{array}$ & $\begin{array}{l}-0.019 \\
(0.041)\end{array}$ & $\begin{array}{c}0.282 \\
(0.174)\end{array}$ \\
\hline$F R E E_{t} \cdot I\left(10<\right.$ dist $\left._{m} \leq 20\right)$ & $\begin{array}{l}-0.112 \\
(0.133)\end{array}$ & $\begin{array}{l}-0.055 \\
(0.065)\end{array}$ & $\begin{array}{c}0.010 \\
(0.083)\end{array}$ & $\begin{array}{c}0.008 \\
(0.070)\end{array}$ \\
\hline \multicolumn{5}{|c|}{ C. Highly educated } \\
\hline$F R E E_{t} \cdot I\left(\right.$ dist $\left._{m} \leq 10\right)$ & $\begin{array}{c}0.291 \\
(0.099)^{* * *}\end{array}$ & $\begin{array}{c}0.070 \\
(0.097)\end{array}$ & $\begin{array}{c}0.064 \\
(0.058)\end{array}$ & $\begin{array}{c}0.113 \\
(0.090)\end{array}$ \\
\hline$F R E E_{t} \cdot I\left(10<\right.$ dist $\left._{m} \leq 20\right)$ & $\begin{array}{l}-0.093 \\
(0.168)\end{array}$ & $\begin{array}{l}-0.106 \\
(0.119)\end{array}$ & $\begin{array}{c}0.066 \\
(0.093)\end{array}$ & $\begin{array}{l}-0.001 \\
(0.108)\end{array}$ \\
\hline \multicolumn{5}{|c|}{ D. Middle educated } \\
\hline$F R E E_{t} \cdot I\left(\right.$ dist $\left._{m} \leq 10\right)$ & $\begin{array}{l}-0.010 \\
(0.102)\end{array}$ & $\begin{array}{l}-0.056 \\
(0.075)\end{array}$ & $\begin{array}{l}-0.074 \\
(0.046)\end{array}$ & $\begin{array}{c}0.267 \\
(0.170)\end{array}$ \\
\hline$F R E E_{t} \cdot I\left(10<\right.$ dist $\left._{m} \leq 20\right)$ & $\begin{array}{l}-0.073 \\
(0.154)\end{array}$ & $\begin{array}{l}-0.053 \\
(0.069)\end{array}$ & $\begin{array}{c}0.026 \\
(0.070)\end{array}$ & $\begin{array}{c}0.001 \\
(0.067)\end{array}$ \\
\hline \multicolumn{5}{|c|}{ E. Low educated } \\
\hline$F R E E_{t} \cdot I\left(\right.$ dist $\left._{m} \leq 10\right)$ & $\begin{array}{l}-0.027 \\
(0.088)\end{array}$ & $\begin{array}{l}-0.065 \\
(0.098)\end{array}$ & $\begin{array}{c}0.030 \\
(0.070)\end{array}$ & $\begin{array}{c}0.576 \\
(0.308)^{*}\end{array}$ \\
\hline$F R E E_{t} \cdot I\left(10<\right.$ dist $\left._{m} \leq 20\right)$ & $\begin{array}{l}-0.108 \\
(0.193)\end{array}$ & $\begin{array}{l}-0.006 \\
(0.083)\end{array}$ & $\begin{array}{c}0.113 \\
(0.138)\end{array}$ & $\begin{array}{c}0.063 \\
(0.120)\end{array}$ \\
\hline Year/Area fixed effects & $\overline{\sqrt{ }}$ & $\overline{\sqrt{ }}$ & $\overline{\sqrt{ }}$ & $\overline{\sqrt{ }}$ \\
\hline Bartik & $\sqrt{ }$ & $\sqrt{ }$ & $\sqrt{ }$ & $\sqrt{ }$ \\
\hline Nuts II trend & $\sqrt{ }$ & $\sqrt{ }$ & $\sqrt{ }$ & $\sqrt{ }$ \\
\hline
\end{tabular}

Notes: ${ }^{* * *},{ }^{* *},{ }^{*}$, denote statistical significance at the $1 \%, 5 \%$ and $10 \%$ level, respectively. Robust standard errors, clustered by commuting zone, are given in parentheses. FRE $E_{t}$ is one for municipalities in the border region after 2004 and in the non-border region after 2007. (dist $\left.t_{m} \leq x\right)$ and $\left(y<\right.$ dist $\left._{m} \leq z\right)$ indicate whether a municipality is located less than $x$ travel minutes or between $y$ and $z$ travel minutes from the next border crossing, respectively. Regressions are weighted using the total number of natives in a cell. Columns (1)-(6) split employment into mutually exclusive and exhaustive industries (omitting agriculture, mining and construction). High-tech manufacturing is NACE Rev 1.1 industries 24, 29, 30,31, 32, 33, 34 and 35 excluding 35.1. Low-tech manufacturers are the remainder manufacturing categories. Knowledge-intensive services are NACE Rev 1.1 industries $61,62,64,65-67,70-74,80,85,92$. Columns (7)-(9) split employment according to the size of the establishment. Large establishments have more than 250 FTEs, medium sized establishments have 50-250 FTEs and small establishments have 5-50 FTE. in Column (10), Public sector affiliation is based on the legal form of the establishment (estimates for private sector omitted). SESS data and $\mathrm{BC}$ data. 
Table 9: Effect of the free movement policy on number of firms by sector and entry of new firms Dependent variable: \# new est. in sector relativ to total est. in sector in 1998

\begin{tabular}{|c|c|c|c|c|c|}
\hline \multirow[t]{3}{*}{ Category of employment } & \multirow[b]{2}{*}{ All } & \multicolumn{2}{|c|}{ Manufacturing } & \multicolumn{2}{|c|}{ Services } \\
\hline & & High-tech & Low-tech & $\begin{array}{l}\text { Knowl.- } \\
\text { intensive }\end{array}$ & $\begin{array}{c}\text { Not-Knowl } \\
\text { intensive }\end{array}$ \\
\hline & $(1)$ & $(2)$ & $(3)$ & $(4)$ & $(5)$ \\
\hline Transition $_{t} \cdot I\left(\right.$ dist $\left._{m} \leq 10\right)$ & $\begin{array}{c}0.017 \\
(0.005)^{* * *}\end{array}$ & $\begin{array}{c}0.036 \\
(0.014)^{* *}\end{array}$ & $\begin{array}{c}0.012 \\
(0.010)\end{array}$ & $\begin{array}{c}0.012 \\
(0.010)\end{array}$ & $\begin{array}{c}0.014 \\
(0.004)^{* * *}\end{array}$ \\
\hline Transition $_{t} \cdot I\left(10<\right.$ dist $\left._{m} \leq 20\right)$ & $\begin{array}{c}0.019 \\
(0.005)^{* * *}\end{array}$ & $\begin{array}{c}0.018 \\
(0.018)\end{array}$ & $\begin{array}{c}0.014 \\
(0.011)\end{array}$ & $\begin{array}{c}0.031 \\
(0.013)^{* *}\end{array}$ & $\begin{array}{c}0.012 \\
(0.005)^{* *}\end{array}$ \\
\hline Transition $_{t} \cdot I\left(20<\right.$ dist $\left._{m} \leq 30\right)$ & $\begin{array}{c}0.024 \\
(0.008)^{* * *}\end{array}$ & $\begin{array}{l}-0.018 \\
(0.016)\end{array}$ & $\begin{array}{c}0.009 \\
(0.008)\end{array}$ & $\begin{array}{c}0.051 \\
(0.012)^{* * *}\end{array}$ & $\begin{array}{c}0.009 \\
(0.005)^{*}\end{array}$ \\
\hline$F R E E_{m, t} \cdot I\left(\right.$ dist $\left._{m} \leq 10\right)$ & $\begin{array}{c}0.034 \\
(0.009)^{* * *}\end{array}$ & $\begin{array}{c}0.062 \\
(0.021)^{* * *}\end{array}$ & $\begin{array}{c}0.033 \\
(0.010)^{* * *}\end{array}$ & $\begin{array}{c}0.039 \\
(0.015)^{* *}\end{array}$ & $\begin{array}{c}0.022 \\
(0.005)^{* * *}\end{array}$ \\
\hline$F R E E_{m, t} \cdot I\left(10<\right.$ dist $\left._{m} \leq 20\right)$ & $\begin{array}{c}0.017 \\
(0.007)^{* *}\end{array}$ & $\begin{array}{c}0.046 \\
(0.018)^{* *}\end{array}$ & $\begin{array}{c}0.015 \\
(0.007)^{* *}\end{array}$ & $\begin{array}{c}0.018 \\
(0.011)^{*}\end{array}$ & $\begin{array}{c}0.010 \\
(0.007)\end{array}$ \\
\hline$F R E E_{m, t} \cdot I\left(20<\right.$ dist $\left._{m} \leq 30\right)$ & $\begin{array}{c}0.028 \\
(0.004)^{* * *}\end{array}$ & $\begin{array}{c}0.023 \\
(0.014)\end{array}$ & $\begin{array}{c}0.012 \\
(0.008)\end{array}$ & $\begin{array}{c}0.045 \\
(0.008)^{* * *}\end{array}$ & $\begin{array}{c}0.021 \\
(0.004)^{* * *}\end{array}$ \\
\hline $\mathrm{R}$-squared & 0.621 & 0.298 & 0.342 & 0.437 & 0.552 \\
\hline Observations & 7960 & 5140 & 7255 & 7490 & 7905 \\
\hline Year/Area fixed effects & $\sqrt{ }$ & $\sqrt{ }$ & $\sqrt{ }$ & $\sqrt{ }$ & $\sqrt{ }$ \\
\hline Bartik & $\sqrt{ }$ & $\sqrt{ }$ & $\sqrt{ }$ & $\sqrt{ }$ & $\sqrt{ }$ \\
\hline Nuts II trend & $\sqrt{ }$ & $\sqrt{ }$ & $\sqrt{ }$ & $\sqrt{ }$ & $\sqrt{ }$ \\
\hline
\end{tabular}

Notes: ${ }^{* * *},{ }^{* *},{ }^{*}$, denote statistical significance at the $1 \%, 5 \%$ and $10 \%$ level, respectively. Robust standard errors, clustered by commuting zone, are given in parentheses. Transition $t$ is one for the period between 2000 and 2003, whereas $F R E E_{t}$ is one from year 2004 onward. (dist $m \leq x)$ and $\left(y<\right.$ dist $\left._{m} \leq z\right)$ indicate whether a municipality is located less than $x$ travel minutes or between $y$ and $z$ travel minutes from the next border crossing, respectively. BC data. 


\title{
The Labor Market Effects of Opening the Border: Evidence from Switzerland \\ Appendix
}

\author{
Andreas Beerli (ETH Zurich), Giovanni Peri (UC Davis)
}

\section{A Additional Results}

Table A1: Characteristics of workers depending on travel time of workplace from the border $199 \underline{\underline{8}}$

\begin{tabular}{|c|c|c|c|c|c|}
\hline \multirow[b]{2}{*}{ Travel time to border crossing (minutes) } & \multicolumn{4}{|c|}{ Border Region } & \multirow{2}{*}{$\begin{array}{c}\text { Non-Border- } \\
\text { Region }\end{array}$} \\
\hline & $0-10 \mathrm{~min}$ & $10-20 \min$ & $20-30 \mathrm{~min}$ & $>30 \mathrm{~min}$ & \\
\hline \multicolumn{6}{|l|}{ Demographic characteristics } \\
\hline Share highly educated & 0.189 & 0.131 & 0.208 & 0.157 & 0.150 \\
\hline Share middle educated & 0.543 & 0.601 & 0.605 & 0.600 & 0.616 \\
\hline Share low educated & 0.268 & 0.269 & 0.187 & 0.242 & 0.234 \\
\hline Mean age & 39.600 & 39.500 & 39.200 & 39.400 & 38.700 \\
\hline Share male & 0.603 & 0.650 & 0.604 & 0.631 & 0.608 \\
\hline Mean log hourly real wage & 3.505 & 3.459 & 3.582 & 3.484 & 3.454 \\
\hline Mean travel time ( $\min$ ) to border & 3.731 & 15.143 & 26.459 & 41.092 & 61.407 \\
\hline Mean travel distance $(\mathrm{km})$ to border & 2.290 & 13.487 & 27.142 & 48.070 & 77.730 \\
\hline \multicolumn{6}{|l|}{ Industry shares } \\
\hline Agriculture/Fishing/Mining & 0.007 & 0.004 & 0.003 & 0.003 & 0.003 \\
\hline Manufacturing & 0.312 & 0.323 & 0.211 & 0.337 & 0.259 \\
\hline Utilities & 0.004 & 0.012 & 0.003 & 0.007 & 0.005 \\
\hline Construction & 0.093 & 0.108 & 0.071 & 0.096 & 0.123 \\
\hline Wholesale/Retail/Repair & 0.158 & 0.221 & 0.177 & 0.204 & 0.224 \\
\hline Hotels/Restaurants & 0.052 & 0.055 & 0.058 & 0.056 & 0.081 \\
\hline Transport/Communication/Storage & 0.056 & 0.052 & 0.058 & 0.054 & 0.056 \\
\hline Financial Intermediation & 0.085 & 0.049 & 0.153 & 0.041 & 0.058 \\
\hline Real Estate/R\&D/IT/Business activities & 0.109 & 0.072 & 0.122 & 0.088 & 0.078 \\
\hline Education & 0.018 & 0.020 & 0.021 & 0.019 & 0.014 \\
\hline Health & 0.078 & 0.057 & 0.086 & 0.075 & 0.072 \\
\hline Personal Services & 0.029 & 0.026 & 0.038 & 0.021 & 0.027 \\
\hline \# municipalities & 388 & 336 & 281 & 561 & 806 \\
\hline Total number of workers & 428,989 & 178,480 & 417,236 & 438,717 & 497,469 \\
\hline
\end{tabular}

Notes: Municipalities in the border region are categorized into four bins according to their travel time in minutes to the next border crossing. SESS data 1998. 
Figure A1: Employment share of immigrants in distance bins

A. Share of immigrants on total employment 1998

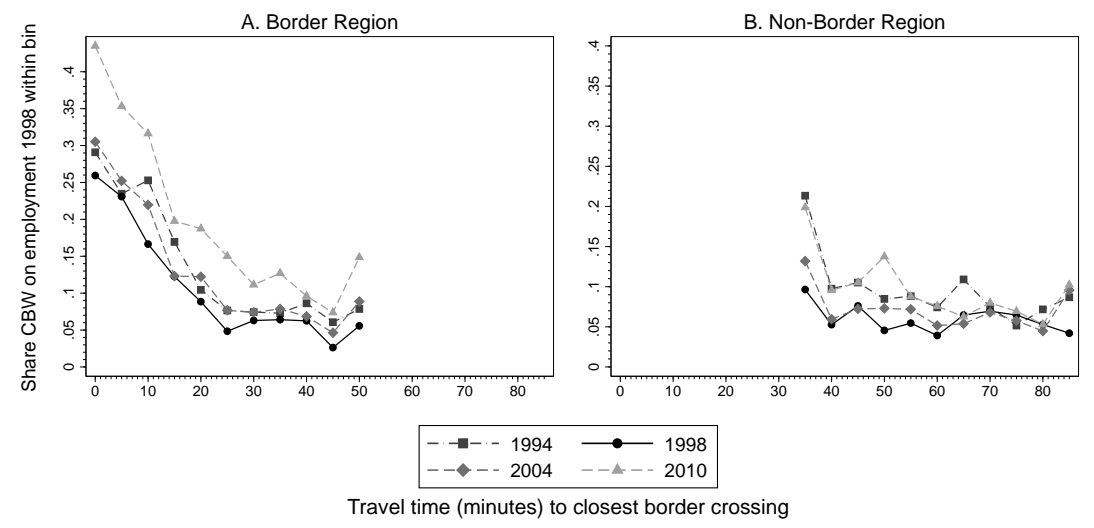

B. Change in share of immigrants on total employment 1998

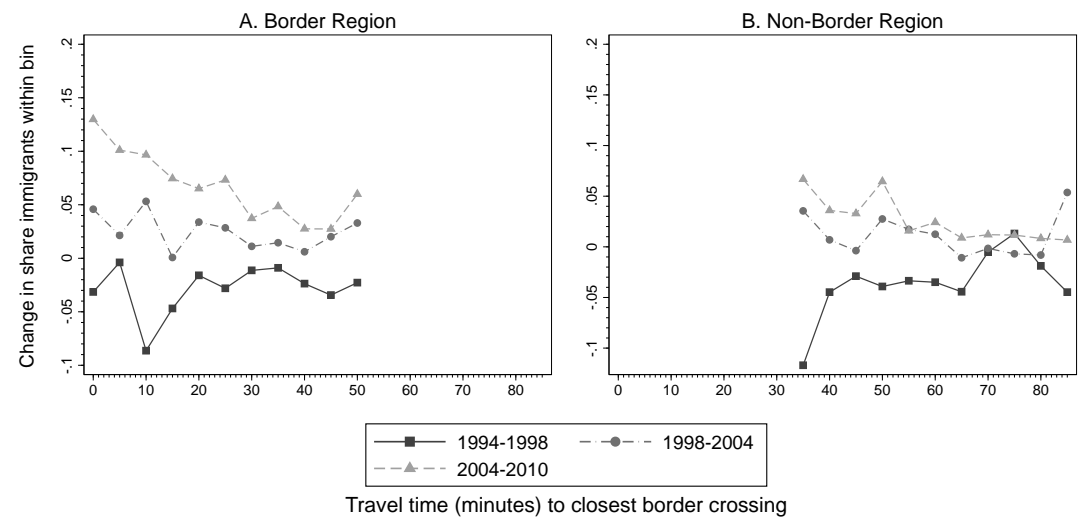

Notes: The figure plots the share of new immigrants (new resident immigrants + cross-border workers) on total employment in 1998 in panel A and the change between those shares in panel B, separately for the border region and the non-border region. Municipalities are grouped into bins of 5 minutes according to their road travel time to the next border crossing. Distance bins with a small number of total workers are omitted, i.e. those with travel time above 50 minutes in the border region and below 35 or above 85 minutes in the non-border region. SESS data.

Figure A2: Effect of free movement policy on share of immigrants, including non-border region in control group

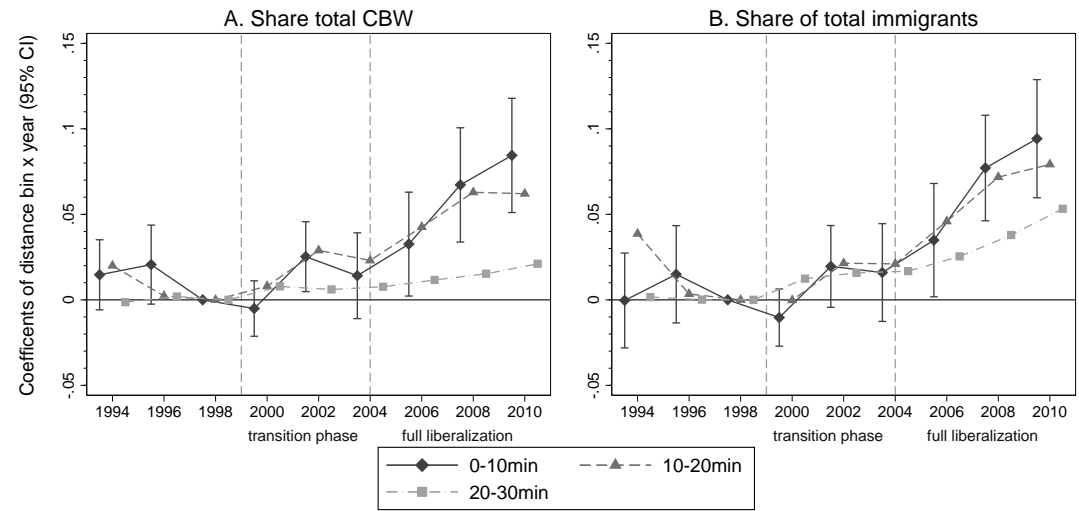

Notes: The figure plots the coefficients and the $95 \%$ confidence interval for the 0 10min distance bin of a regression based on equation (3) with the share of crossborder workers on total employment in 1998 as dependent variable. Regressions are weighted using the total workforce in 1998 in a cell and include NUTS II trends and the Bartik measure. The samples includes municipalities in the border region and non-border region. Standard errors are clustered on the CZ level. SESS data. 
Table A2: Effect on share of CBW in occupation groups relative to total employment in 1998 Dependent variable: number of CBW with occupation relative to total employment in 1998

\begin{tabular}{|c|c|c|c|c|c|c|c|c|}
\hline & $(1)$ & $(2)$ & $(3)$ & $(4)$ & $(5)$ & $(6)$ & $(7)$ & $(8)$ \\
\hline \multicolumn{9}{|c|}{ A. High-paying occupations } \\
\hline & Managment & $\begin{array}{c}\text { Logistics } \\
\text { Strategy } \\
\text { department }\end{array}$ & $\begin{array}{l}\text { Evaluation } \\
\text { Consulting } \\
\text { Certification }\end{array}$ & Trading & $\mathrm{R} \& \mathrm{D}$ & $\begin{array}{c}\text { Analysis } \\
\text { Programming } \\
\text { Operating }\end{array}$ & $\begin{array}{l}\text { Planing } \\
\text { Design }\end{array}$ & Education \\
\hline$F R E E_{t} \cdot I\left(\right.$ dist $\left._{m} \leq 10\right)$ & $\begin{array}{c}0.002 \\
(0.000)^{* * *}\end{array}$ & $\begin{array}{c}0.002 \\
(0.000)^{* * *}\end{array}$ & $\begin{array}{c}0.004 \\
(0.001)^{* * *}\end{array}$ & $\begin{array}{c}0.001 \\
(0.000)^{* *}\end{array}$ & $\begin{array}{c}0.005 \\
(0.001)^{* * *}\end{array}$ & $\begin{array}{c}0.003 \\
(0.001)^{* * *}\end{array}$ & $\begin{array}{c}0.001 \\
(0.000)^{* * *}\end{array}$ & $\begin{array}{c}0.002 \\
(0.000)^{* * *}\end{array}$ \\
\hline$F R E E_{t} \cdot I\left(10<\right.$ dist $\left._{m} \leq 20\right)$ & 0.001 & 0.001 & 0.002 & 0.001 & 0.002 & 0.001 & 0.002 & 0.002 \\
\hline$F R E E_{t} \cdot I\left(20<\right.$ dist $\left._{m} \leq 30\right)$ & $\begin{array}{c}0.000 \\
(0.000)^{*}\end{array}$ & $(0.000)^{* * *}$ & $\begin{array}{c}0.000 \\
(0.000)\end{array}$ & $\begin{array}{l}0.000 \\
(0.000)\end{array}$ & $\begin{array}{c}0.001 \\
(0.001)\end{array}$ & $\begin{array}{c}0.001 \\
(0.000)^{*}\end{array}$ & $\begin{array}{l}-0.000 \\
(0.001)\end{array}$ & $\begin{array}{c}0.000 \\
(0.000)\end{array}$ \\
\hline Observations & 10053 & 10053 & 10053 & 10053 & 10053 & 10053 & 10053 & 10053 \\
\hline \multicolumn{9}{|c|}{ B. Middle-paying occupations } \\
\hline & $\begin{array}{l}\text { Machine } \\
\text { Operators }\end{array}$ & $\begin{array}{l}\text { Accounting } \\
\text { Human } \\
\text { Resources }\end{array}$ & Clerks & $\begin{array}{l}\text { Other } \\
\text { clerical } \\
\text { occ. }\end{array}$ & Security & $\begin{array}{c}\text { Medical } \\
\text { Sursing } \\
\text { Social work }\end{array}$ & $\begin{array}{c}\text { Culture } \\
\text { Entertain. } \\
\text { Information }\end{array}$ & Other \\
\hline$F R E E_{t} \cdot I\left(\right.$ dist $\left._{m} \leq 10\right)$ & $\begin{array}{c}0.003 \\
(0.001)^{* * *}\end{array}$ & $\begin{array}{c}0.002 \\
(0.000)^{* * *}\end{array}$ & $\begin{array}{c}0.002 \\
(0.000)^{* * *}\end{array}$ & $\begin{array}{c}0.003 \\
(0.001)^{* * *}\end{array}$ & $\begin{array}{c}0.001 \\
(0.000)^{* *}\end{array}$ & $\begin{array}{c}0.004 \\
(0.000)^{* * *}\end{array}$ & $\begin{array}{c}0.001 \\
(0.000)^{* * *}\end{array}$ & $\begin{array}{l}-0.006 \\
(0.003)^{* *}\end{array}$ \\
\hline$F R E E_{t} \cdot I\left(10<\right.$ dist $\left._{m} \leq 20\right)$ & 0.005 & 0.001 & $\begin{array}{c}0.000 \\
(0.000)\end{array}$ & 0.002 & 0.000 & 0.001 & $\begin{array}{c}0.000 \\
0.000)\end{array}$ & -0.001 \\
\hline$F R E E_{t} \cdot I\left(20<\right.$ dist $\left._{m} \leq 30\right)$ & 0.001 & 0.000 & 0.000 & 0.001 & $\begin{array}{c}0.000 \\
(0.000)\end{array}$ & 0.001 & $\begin{array}{c}0.000 \\
(0.000)\end{array}$ & -0.000 \\
\hline Observations & 10053 & 10053 & 10053 & 10053 & 10053 & 10053 & 10053 & 10053 \\
\hline \multicolumn{9}{|c|}{ C. Low-paying occupations } \\
\hline & $\begin{array}{l}\text { Manufact. } \\
\text { Processing }\end{array}$ & Construction & $\begin{array}{l}\text { Restoration } \\
\text { Craft }\end{array}$ & Retail & Transport & $\begin{array}{l}\text { Manicure, } \\
\text { laundary }\end{array}$ & Cleaning & Restauration \\
\hline$F R E E_{t} \cdot I\left(\right.$ dist $\left._{m} \leq 10\right)$ & $\begin{array}{c}0.003 \\
(0.004)\end{array}$ & $\begin{array}{c}0.001 \\
(0.001)\end{array}$ & $\begin{array}{c}0.000 \\
(0.000)^{* *}\end{array}$ & $\begin{array}{c}0.000 \\
(0.002)\end{array}$ & $\begin{array}{c}0.000 \\
(0.001)\end{array}$ & $\begin{array}{c}0.001 \\
(0.000)^{* *}\end{array}$ & $\begin{array}{c}0.000 \\
(0.000)^{* *}\end{array}$ & $\begin{array}{c}0.002 \\
(0.002)\end{array}$ \\
\hline$F R E E_{t} \cdot I\left(10<\right.$ dist $\left._{m} \leq 20\right)$ & $\begin{array}{c}0.006 \\
(0.003)^{*}\end{array}$ & $\begin{array}{c}0.003 \\
(0.002)\end{array}$ & $\begin{array}{c}0.000 \\
(0.000)^{*}\end{array}$ & $\begin{array}{l}-0.000 \\
(0.001)\end{array}$ & $\begin{array}{c}0.001 \\
(0.001)^{*}\end{array}$ & $\begin{array}{l}0.000 \\
(0.000)^{* *}\end{array}$ & $\begin{array}{c}0.001 \\
(0.000)^{*}\end{array}$ & $\begin{array}{c}0.003 \\
(0.002)\end{array}$ \\
\hline$F R E E_{t} \cdot I\left(20<\right.$ dist $\left._{m} \leq 30\right)$ & $\begin{array}{c}0.003 \\
(0.002)^{*}\end{array}$ & $\begin{array}{c}0.000 \\
(0.001)\end{array}$ & $\begin{array}{c}0.000 \\
(0.000)\end{array}$ & $\begin{array}{c}0.001 \\
(0.000)^{* * *}\end{array}$ & $\begin{array}{c}0.000 \\
(0.000)\end{array}$ & $\begin{array}{c}0.000 \\
(0.000)^{*}\end{array}$ & $\begin{array}{c}0.000 \\
(0.000)\end{array}$ & $\begin{array}{c}0.001 \\
(0.001)\end{array}$ \\
\hline R-squared & 10053 & 10053 & 10053 & 10053 & 10053 & 10053 & 10053 & 10053 \\
\hline
\end{tabular}

Notes: ${ }^{* * *},{ }^{* *},{ }^{*}$, denote statistical significance at the $1 \%, 5 \%$ and $10 \%$ level, respectively. Robust standard errors, clustered by commuting zone, are given in parentheses. FRE $E_{t}$ is one from year 2004 onward. $\left(\right.$ dist $\left._{m} \leq x\right)$ and $\left(y<\right.$ dist $\left._{m} \leq z\right)$ indicate whether a municipality is located less than $x$ travel minutes or between $y$ and $z$ travel minutes from the next border crossing, respectively. Regressions are weighted using the total number of workers in 1998. The number of CBW in municipality $m$ and year $t$ is split into 24 different mutually exclusive and exhaustive occupations categories available in the SESS data. 
Table A3: Effect of free movement policy on monthly wages of natives Dependent variable: Average log monthly wages of natives by education groups

\begin{tabular}{|c|c|c|}
\hline & $(1)$ & $(2)$ \\
\hline \multicolumn{3}{|c|}{ A. All education groups } \\
\hline$F R E E_{t} \cdot I\left(\right.$ dist $\left._{m} \leq 10\right)$ & $\begin{array}{l}-0.030 \\
(0.042)\end{array}$ & $\begin{array}{l}-0.034 \\
(0.041)\end{array}$ \\
\hline$F R E E_{t} \cdot I\left(10<\right.$ dist $\left._{m} \leq 20\right)$ & $\begin{array}{l}-0.010 \\
(0.016)\end{array}$ & $\begin{array}{l}-0.010 \\
(0.015)\end{array}$ \\
\hline$F R E E_{t} \cdot I\left(20<\right.$ dist $\left._{m} \leq 30\right)$ & $\begin{array}{c}0.007 \\
(0.010)\end{array}$ & $\begin{array}{c}0.008 \\
(0.009)\end{array}$ \\
\hline $\begin{array}{l}\text { R-squared } \\
\text { Observations }\end{array}$ & $\begin{array}{l}0.569 \\
11729\end{array}$ & $\begin{array}{l}0.561 \\
17619\end{array}$ \\
\hline \multicolumn{3}{|c|}{ B. Highly educated } \\
\hline$F R E E_{t} \cdot I\left(\right.$ dist $\left._{m} \leq 10\right)$ & $\begin{array}{c}0.055 \\
(0.022)^{* *}\end{array}$ & $\begin{array}{c}0.046 \\
(0.020)^{* *}\end{array}$ \\
\hline$F R E E_{t} \cdot I\left(10<\right.$ dist $\left._{m} \leq 20\right)$ & $\begin{array}{c}0.042 \\
(0.019)^{* *}\end{array}$ & $\begin{array}{c}0.032 \\
(0.016)^{* *}\end{array}$ \\
\hline$F R E E_{t} \cdot I\left(20<\right.$ dist $\left._{m} \leq 30\right)$ & $\begin{array}{c}0.069 \\
(0.023)^{* * *}\end{array}$ & $\begin{array}{c}0.061 \\
(0.019)^{* * *}\end{array}$ \\
\hline $\begin{array}{l}\text { R-squared } \\
\text { Observations }\end{array}$ & $\begin{array}{l}0.532 \\
8781\end{array}$ & $\begin{array}{l}0.524 \\
13008\end{array}$ \\
\hline \multicolumn{3}{|c|}{ C. Middle educated } \\
\hline$F R E E_{t} \cdot I\left(\right.$ dist $\left._{m} \leq 10\right)$ & $\begin{array}{l}-0.036 \\
(0.037)\end{array}$ & $\begin{array}{l}-0.039 \\
(0.036)\end{array}$ \\
\hline$F R E E_{t} \cdot I\left(10<\right.$ dist $\left._{m} \leq 20\right)$ & $\begin{array}{l}-0.017 \\
(0.015)\end{array}$ & $\begin{array}{l}-0.017 \\
(0.014)\end{array}$ \\
\hline$F R E E_{t} \cdot I\left(20<\right.$ dist $\left._{m} \leq 30\right)$ & $\begin{array}{l}-0.008 \\
(0.009)\end{array}$ & $\begin{array}{l}-0.009 \\
(0.009)\end{array}$ \\
\hline $\begin{array}{l}\text { R-squared } \\
\text { Observations }\end{array}$ & $\begin{array}{l}0.522 \\
11283\end{array}$ & $\begin{array}{l}0.513 \\
16944\end{array}$ \\
\hline \multicolumn{3}{|c|}{ D. Low educated } \\
\hline$F R E E_{t} \cdot I\left(\right.$ dist $\left._{m} \leq 10\right)$ & $\begin{array}{l}-0.061 \\
(0.036)^{*}\end{array}$ & $\begin{array}{l}-0.056 \\
(0.035)\end{array}$ \\
\hline$F R E E_{t} \cdot I\left(10<\right.$ dist $\left._{m} \leq 20\right)$ & $\begin{array}{c}-0.069 \\
(0.038)^{*}\end{array}$ & $\begin{array}{c}-0.062 \\
(0.037)^{*}\end{array}$ \\
\hline$F R E E_{t} \cdot I\left(20<\right.$ dist $\left._{m} \leq 30\right)$ & $\begin{array}{l}-0.070 \\
(0.037)^{*}\end{array}$ & $\begin{array}{l}-0.060 \\
(0.036)\end{array}$ \\
\hline R-squared & 0.468 & 0.446 \\
\hline Observations & 9398 & 13914 \\
\hline Including NBR Sample & & $\sqrt{ }$ \\
\hline $\begin{array}{l}\text { Year/Area fixed effects } \\
\text { Bartik } \\
\text { Nuts II trend }\end{array}$ & $\begin{array}{l}\sqrt{ } \\
\sqrt{ } \\
\sqrt{ }\end{array}$ & $\begin{array}{l}\sqrt{ } \\
\sqrt{ } \\
\sqrt{ }\end{array}$ \\
\hline
\end{tabular}

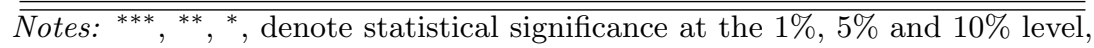
respectively. Robust standard errors, clustered by commuting zone, are given in parentheses. FRE $E_{t}$ is one from year 2004 onward. (dist $\left.t_{m} \leq x\right)$ and $\left(y<\right.$ dist $\left._{m} \leq z\right)$ indicate whether a municipality is located less than $x$ travel minutes or between $y$ and $z$ travel minutes from the next border crossing, respectively. Regressions are weighted using the total number of natives in a cell. SESS data. 
Table A4: Effect of free movement policy on wage levels of natives, robustness with respect to panel selection

Dependent variable: Average log hourly wages of natives by education groups

\begin{tabular}{|c|c|c|c|c|}
\hline \multirow[t]{2}{*}{ Sample selection criteria } & \multicolumn{2}{|c|}{ Top yearly $80 \%$ (of aggregate) } & \multicolumn{2}{|c|}{ Balanced panel (of aggregate) } \\
\hline & $(1)$ & $(2)$ & $(3)$ & $(4)$ \\
\hline \multicolumn{5}{|c|}{ A. All education groups } \\
\hline$F R E E_{t} \cdot I\left(\right.$ dist $\left._{m} \leq 10\right)$ & $\begin{array}{l}-0.020 \\
(0.024)\end{array}$ & $\begin{array}{l}-0.019 \\
(0.024)\end{array}$ & $\begin{array}{l}-0.019 \\
(0.024)\end{array}$ & $\begin{array}{l}-0.019 \\
(0.024)\end{array}$ \\
\hline$F R E E_{t} \cdot I\left(10<\right.$ dist $\left._{m} \leq 20\right)$ & $\begin{array}{c}0.004 \\
(0.008)\end{array}$ & $\begin{array}{c}0.006 \\
(0.007)\end{array}$ & $\begin{array}{c}0.005 \\
(0.008)\end{array}$ & $\begin{array}{c}0.006 \\
(0.008)\end{array}$ \\
\hline$F R E E_{t} \cdot I\left(20<\right.$ dist $\left._{m} \leq 30\right)$ & $\begin{array}{c}0.001 \\
(0.006)\end{array}$ & $\begin{array}{c}0.003 \\
(0.005)\end{array}$ & $\begin{array}{c}0.001 \\
(0.006)\end{array}$ & $\begin{array}{c}0.003 \\
(0.006)\end{array}$ \\
\hline R-squared & 0.779 & 0.774 & 0.792 & 0.785 \\
\hline Observations & 9330 & 13968 & 7116 & 10338 \\
\hline \multicolumn{5}{|c|}{ B. Highly educated } \\
\hline$F R E E_{t} \cdot I\left(\right.$ dist $\left._{m} \leq 10\right)$ & $\begin{array}{c}0.033 \\
(0.011)^{* * *}\end{array}$ & $\begin{array}{c}0.031 \\
(0.010)^{* * *}\end{array}$ & $\begin{array}{c}0.035 \\
(0.011)^{* * *}\end{array}$ & $\begin{array}{c}0.033 \\
(0.010)^{* * *}\end{array}$ \\
\hline$F R E E_{t} \cdot I\left(10<\right.$ dist $\left._{m} \leq 20\right)$ & $\begin{array}{c}0.029 \\
(0.010)^{* * *}\end{array}$ & $\begin{array}{c}0.027 \\
(0.008)^{* * *}\end{array}$ & $\begin{array}{c}0.031 \\
(0.010)^{* * *}\end{array}$ & $\begin{array}{c}0.028 \\
(0.009)^{* * *}\end{array}$ \\
\hline$F R E E_{t} \cdot I\left(20<\right.$ dist $\left._{m} \leq 30\right)$ & $\begin{array}{c}0.012 \\
(0.011)\end{array}$ & $\begin{array}{c}0.011 \\
(0.009)\end{array}$ & $\begin{array}{c}0.012 \\
(0.011)\end{array}$ & $\begin{array}{c}0.010 \\
(0.009)\end{array}$ \\
\hline R-squared & 0.639 & 0.620 & 0.638 & 0.616 \\
\hline Observations & 8012 & 11853 & 6236 & 9049 \\
\hline \multicolumn{5}{|c|}{ C. Middle educated } \\
\hline$F R E E_{t} \cdot I\left(\right.$ dist $\left._{m} \leq 10\right)$ & $\begin{array}{l}-0.025 \\
(0.022)\end{array}$ & $\begin{array}{l}-0.024 \\
(0.022)\end{array}$ & $\begin{array}{l}-0.025 \\
(0.022)\end{array}$ & $\begin{array}{l}-0.024 \\
(0.022)\end{array}$ \\
\hline$F R E E_{t} \cdot I\left(10<\right.$ dist $\left._{m} \leq 20\right)$ & $\begin{array}{l}-0.002 \\
(0.008)\end{array}$ & $\begin{array}{l}-0.000 \\
(0.008)\end{array}$ & $\begin{array}{l}-0.001 \\
(0.008)\end{array}$ & $\begin{array}{c}0.000 \\
(0.008)\end{array}$ \\
\hline$F R E E_{t} \cdot I\left(20<\right.$ dist $\left._{m} \leq 30\right)$ & $\begin{array}{l}-0.004 \\
(0.005)\end{array}$ & $\begin{array}{l}-0.002 \\
(0.005)\end{array}$ & $\begin{array}{l}-0.004 \\
(0.005)\end{array}$ & $\begin{array}{l}-0.003 \\
(0.005)\end{array}$ \\
\hline R-squared & 0.695 & 0.693 & 0.708 & 0.706 \\
\hline Observations & 9247 & 13823 & 7029 & 10212 \\
\hline \multicolumn{5}{|c|}{ D. Low educated } \\
\hline$F R E E_{t} \cdot I\left(\right.$ dist $\left._{m} \leq 10\right)$ & $\begin{array}{c}-0.031 \\
(0.015)^{* *}\end{array}$ & $\begin{array}{c}-0.027 \\
(0.016)^{*}\end{array}$ & $\begin{array}{c}-0.033 \\
(0.015)^{* *}\end{array}$ & $\begin{array}{c}-0.028 \\
(0.016)^{*}\end{array}$ \\
\hline$F R E E_{t} \cdot I\left(10<\right.$ dist $\left._{m} \leq 20\right)$ & $\begin{array}{l}-0.020 \\
(0.015)\end{array}$ & $\begin{array}{l}-0.015 \\
(0.015)\end{array}$ & $\begin{array}{l}-0.021 \\
(0.015)\end{array}$ & $\begin{array}{l}-0.017 \\
(0.016)\end{array}$ \\
\hline$F R E E_{t} \cdot I\left(20<\right.$ dist $\left._{m} \leq 30\right)$ & $\begin{array}{c}-0.028 \\
(0.013)^{* *}\end{array}$ & $\begin{array}{c}-0.022 \\
(0.013)^{*}\end{array}$ & $\begin{array}{c}-0.032 \\
(0.013)^{* *}\end{array}$ & $\begin{array}{c}-0.026 \\
(0.013)^{* *}\end{array}$ \\
\hline R-squared & 0.545 & 0.517 & 0.541 & 0.509 \\
\hline Observations & 8313 & 12394 & 6555 & 9535 \\
\hline Including NBR Sample & & $\sqrt{ }$ & & $\sqrt{ }$ \\
\hline $\begin{array}{l}\text { Year/Area fixed effects } \\
\text { Bartik } \\
\text { Nuts II trend }\end{array}$ & $\begin{array}{l}\sqrt{ } \\
\sqrt{ } \\
\sqrt{ } \\
\end{array}$ & $\begin{array}{l}\sqrt{ } \\
\sqrt{ } \\
\sqrt{ }\end{array}$ & $\begin{array}{l}\sqrt{ } \\
\sqrt{ } \\
\sqrt{ }\end{array}$ & $\begin{array}{l}\sqrt{ } \\
\sqrt{ } \\
\sqrt{ }\end{array}$ \\
\hline
\end{tabular}

Notes: ${ }^{{ }^{* * *},{ }^{* *},{ }^{*}, \text { denote statistical significance at the } 1 \%, 5 \% \text { and } 10 \% \text { level, respectively. Robust standard }}$ errors, clustered by commuting zone, are given in parentheses. FRE $E_{t}$ is one from year 2004 onward. $\left(\right.$ dist $\left._{m} \leq x\right)$ and $\left(y<\right.$ dist $\left._{m} \leq z\right)$ indicate whether a municipality is located less than $x$ travel minutes or between $y$ and $z$ travel minutes from the next border crossing, respectively. Regressions are weighted using the total number of natives in a cell. In columns (1)-(2), municipalities below the bottom 20th percentile of local employment are dropped. Column (3)-(4) restrict the sample to those municipalities that have non-missing aggregate employment each year. SESS data. 
Table A5: Effect of free movement policy on hours worked of natives, robustness with respect to panel selection

Dependent variable: Log total hours worked by natives, by education groups

\begin{tabular}{|c|c|c|c|c|}
\hline \multirow[t]{2}{*}{ Sample selection criteria } & \multicolumn{2}{|c|}{ Top yearly $80 \%$ (of aggregate) } & \multicolumn{2}{|c|}{ Balanced panel (of aggregate) } \\
\hline & $(1)$ & $(2)$ & $(3)$ & $(4)$ \\
\hline \multicolumn{5}{|c|}{ A. All education groups } \\
\hline$F R E E_{t} \cdot I\left(\right.$ dist $\left._{m} \leq 10\right)$ & $\begin{array}{c}0.035 \\
(0.054)\end{array}$ & $\begin{array}{c}0.030 \\
(0.053)\end{array}$ & $\begin{array}{c}0.022 \\
(0.053)\end{array}$ & $\begin{array}{c}0.018 \\
(0.052)\end{array}$ \\
\hline$F R E E_{t} \cdot I\left(10<\right.$ dist $\left._{m} \leq 20\right)$ & $\begin{array}{l}-0.036 \\
(0.046)\end{array}$ & $\begin{array}{l}-0.039 \\
(0.047)\end{array}$ & $\begin{array}{l}-0.033 \\
(0.046)\end{array}$ & $\begin{array}{l}-0.036 \\
(0.048)\end{array}$ \\
\hline$F R E E_{t} \cdot I\left(20<\right.$ dist $\left._{m} \leq 30\right)$ & $\begin{array}{c}0.025 \\
(0.023)\end{array}$ & $\begin{array}{c}0.020 \\
(0.020)\end{array}$ & $\begin{array}{c}0.020 \\
(0.023)\end{array}$ & $\begin{array}{c}0.015 \\
(0.020)\end{array}$ \\
\hline R-squared & 0.977 & 0.974 & 0.977 & 0.974 \\
\hline Observations & 9330 & 13969 & 7119 & 10341 \\
\hline \multicolumn{5}{|c|}{ B. Highly educated } \\
\hline$F R E E_{t} \cdot I\left(\right.$ dist $\left._{m} \leq 10\right)$ & $\begin{array}{c}0.056 \\
(0.036)\end{array}$ & $\begin{array}{c}0.052 \\
(0.031)^{*}\end{array}$ & $\begin{array}{c}0.047 \\
(0.034)\end{array}$ & $\begin{array}{c}0.044 \\
(0.030)\end{array}$ \\
\hline$F R E E_{t} \cdot I\left(10<\right.$ dist $\left._{m} \leq 20\right)$ & $\begin{array}{c}0.030 \\
(0.078)\end{array}$ & $\begin{array}{c}0.027 \\
(0.075)\end{array}$ & $\begin{array}{c}0.038 \\
(0.078)\end{array}$ & $\begin{array}{c}0.036 \\
(0.075)\end{array}$ \\
\hline$F R E E_{t} \cdot I\left(20<\right.$ dist $\left._{m} \leq 30\right)$ & $\begin{array}{c}0.101 \\
(0.040)^{* *}\end{array}$ & $\begin{array}{c}0.097 \\
(0.034)^{* * *}\end{array}$ & $\begin{array}{c}0.095 \\
(0.041)^{* *}\end{array}$ & $\begin{array}{c}0.091 \\
(0.035)^{* *}\end{array}$ \\
\hline R-squared & 0.975 & 0.973 & 0.976 & 0.973 \\
\hline Observations & 8032 & 11879 & 6251 & 9069 \\
\hline \multicolumn{5}{|c|}{ C. Middle educated } \\
\hline$F R E E_{t} \cdot I\left(\right.$ dist $\left._{m} \leq 10\right)$ & $\begin{array}{l}-0.008 \\
(0.051)\end{array}$ & $\begin{array}{l}-0.013 \\
(0.049)\end{array}$ & $\begin{array}{l}-0.023 \\
(0.050)\end{array}$ & $\begin{array}{l}-0.028 \\
(0.048)\end{array}$ \\
\hline$F R E E_{t} \cdot I\left(10<\right.$ dist $\left._{m} \leq 20\right)$ & $\begin{array}{l}-0.052 \\
(0.042)\end{array}$ & $\begin{array}{l}-0.054 \\
(0.043)\end{array}$ & $\begin{array}{l}-0.047 \\
(0.043)\end{array}$ & $\begin{array}{l}-0.050 \\
(0.043)\end{array}$ \\
\hline$F R E E_{t} \cdot I\left(20<\right.$ dist $\left._{m} \leq 30\right)$ & $\begin{array}{l}-0.012 \\
(0.031)\end{array}$ & $\begin{array}{l}-0.015 \\
(0.026)\end{array}$ & $\begin{array}{l}-0.018 \\
(0.032)\end{array}$ & $\begin{array}{l}-0.022 \\
(0.027)\end{array}$ \\
\hline R-squared & 0.974 & 0.970 & 0.974 & 0.971 \\
\hline Observations & 9247 & 13823 & 7031 & 10214 \\
\hline \multicolumn{5}{|c|}{ D. Low educated } \\
\hline$F R E E_{t} \cdot I\left(\right.$ dist $\left._{m} \leq 10\right)$ & $\begin{array}{c}0.236 \\
(0.159)\end{array}$ & $\begin{array}{c}0.226 \\
(0.156)\end{array}$ & $\begin{array}{c}0.220 \\
(0.160)\end{array}$ & $\begin{array}{c}0.219 \\
(0.158)\end{array}$ \\
\hline$F R E E_{t} \cdot I\left(10<\right.$ dist $\left._{m} \leq 20\right)$ & $\begin{array}{l}-0.001 \\
(0.069)\end{array}$ & $\begin{array}{l}-0.012 \\
(0.068)\end{array}$ & $\begin{array}{l}-0.012 \\
(0.071)\end{array}$ & $\begin{array}{l}-0.015 \\
(0.071)\end{array}$ \\
\hline$F R E E_{t} \cdot I\left(20<\right.$ dist $\left._{m} \leq 30\right)$ & $\begin{array}{c}0.032 \\
(0.043)\end{array}$ & $\begin{array}{c}0.019 \\
(0.042)\end{array}$ & $\begin{array}{c}0.021 \\
(0.044)\end{array}$ & $\begin{array}{c}0.014 \\
(0.043)\end{array}$ \\
\hline R-squared & 0.924 & 0.915 & 0.924 & 0.913 \\
\hline Observations & 8313 & 12394 & 6555 & 9535 \\
\hline Including NBR Sample & & $\sqrt{ }$ & & $\sqrt{ }$ \\
\hline $\begin{array}{l}\text { Year/Area fixed effects } \\
\text { Bartik } \\
\text { Nuts II trend }\end{array}$ & $\begin{array}{l}\sqrt{ } \\
\sqrt{ } \\
\sqrt{ }\end{array}$ & $\begin{array}{l}\sqrt{ } \\
\sqrt{ } \\
\sqrt{ }\end{array}$ & $\begin{array}{l}\sqrt{ } \\
\sqrt{ } \\
\sqrt{ }\end{array}$ & $\begin{array}{l}\sqrt{ } \\
\sqrt{ } \\
\sqrt{ }\end{array}$ \\
\hline
\end{tabular}

Notes: ${ }^{{ }^{* * *},{ }^{* *},{ }^{*}, \text { denote statistical significance at the } 1 \%, 5 \% \text { and } 10 \% \text { level, respectively. Robust standard }}$ errors, clustered by commuting zone, are given in parentheses. FRE $E_{t}$ is one from year 2004 onward. $\left(\right.$ dist $\left._{m} \leq x\right)$ and $\left(y<\right.$ dist $\left._{m} \leq z\right)$ indicate whether a municipality is located less than $x$ travel minutes or between $y$ and $z$ travel minutes from the next border crossing, respectively. Regressions are weighted using the total number of natives in a cell. In columns (1)-(2), municipalities below the bottom 20th percentile of local employment are dropped. Column (3)-(4) restrict the sample to those municipalities that have non-missing aggregate employment each year. SESS data. 
Figure A3: Event analysis of effect of free movement policy on wage levels of natives, robustness check using alternative distance decomposition and definition of skill groups

\section{I. $15 \mathrm{~min}$ distance bins}
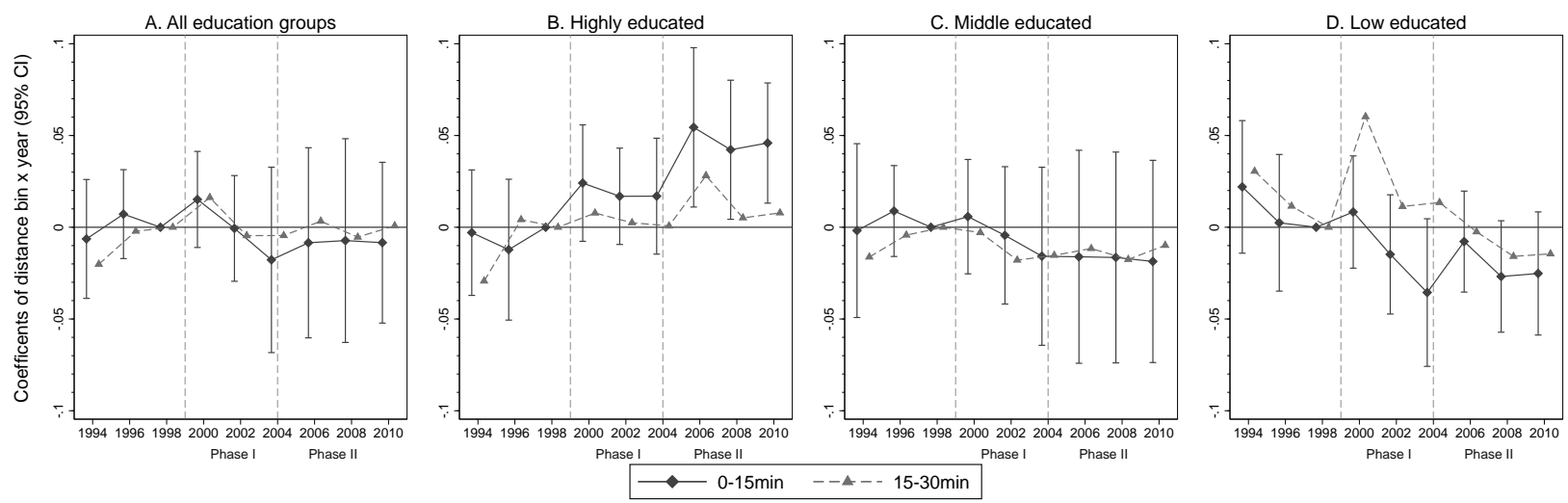

II. Wage tercile groups (10min bin only)
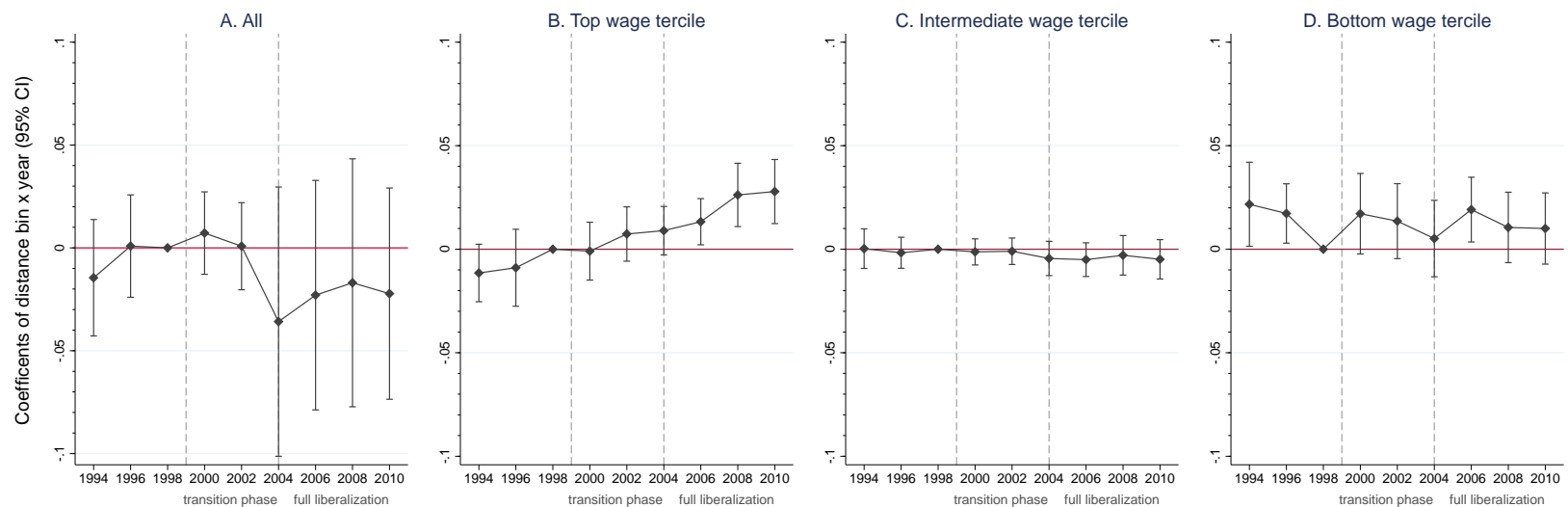

III. Occupation groups (10min bin only)
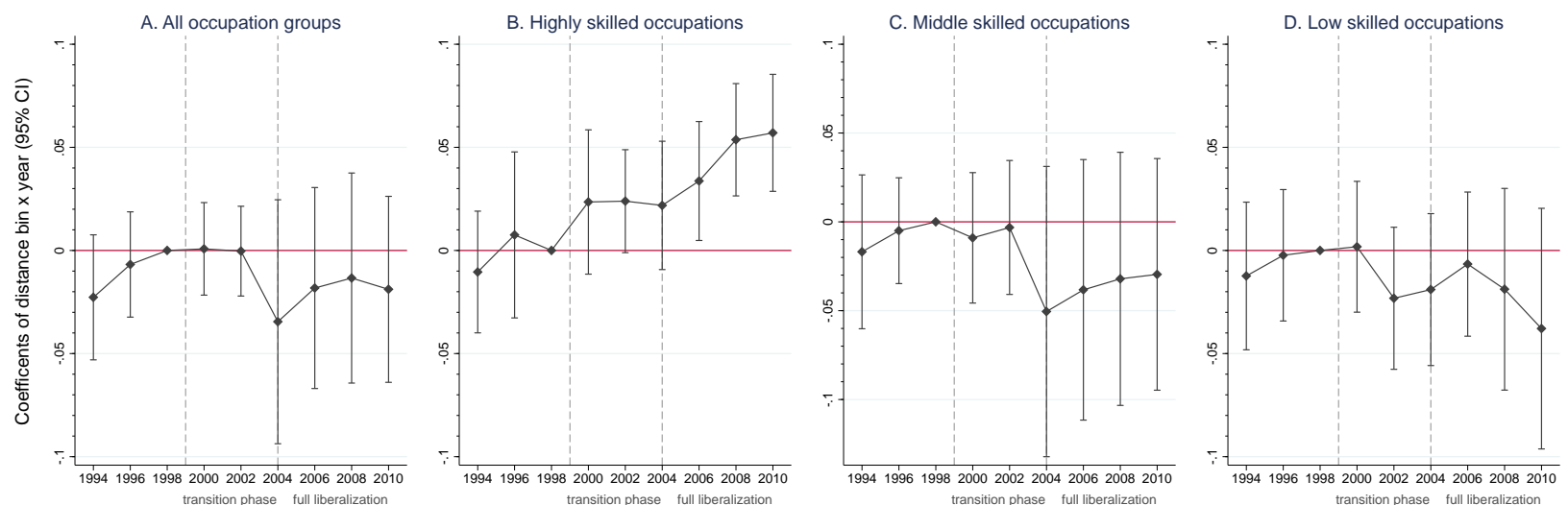

Notes: The figure plots the coefficients (and the $95 \%$ confidence interval for the $0-15 \mathrm{~min}$ or 0-10min distance bin) of a regression based on equation (3) with the average log hourly wage of an education group of native workers as dependent variable. Regressions are weighted using the number of native in a cell and include NUTS II trends and the education specific Bartik measure. Standard errors are clustered on the CZ level. The sample includes only municipalities in the border region. In panel III, the each occupation is allocated according to their share of employment by education group. Occupations with more than $30 \%$ of employment with high education are high skilled occupations (Management, R\&D, Evaluation/Consulting/Certification, Education, Logistics/Strategy department, Planing/Design). Occupations with more than 30\% of employment with low education are low skilled occupations (Construction, Transport, Manufacturing/Processing, Restoration/Craft, Cleaning, Hotels/Restaurants, Manicure/Laundry) The remaining occupations are middle skilled occupations (Trading, Accounting/HR, Culture/Entertainment/Information, Machine Operators, Clerks, Medical/Nursing/Social Work, Security, Retail). SESS data. 
Figure A4: Event analysis of effect of free movement policy on hours worked by natives, robustness check using alternative distance decomposition and definition of skill groups

I. $15 \mathrm{~min}$ distance bins
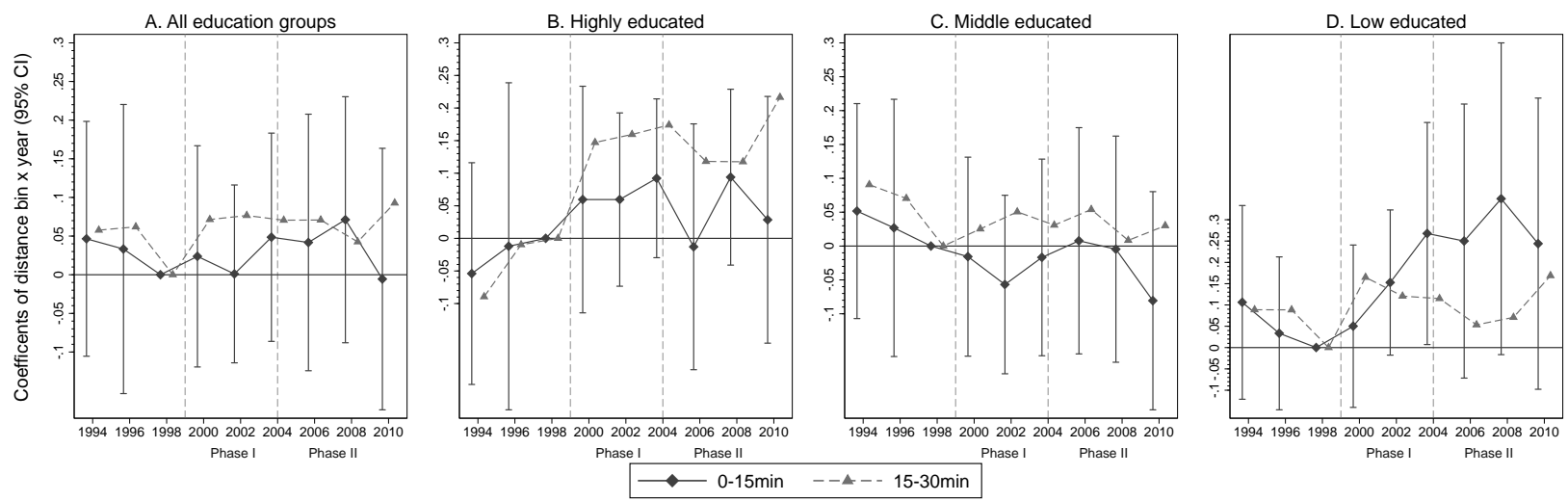

II. Wage tercile groups (10min bin only)
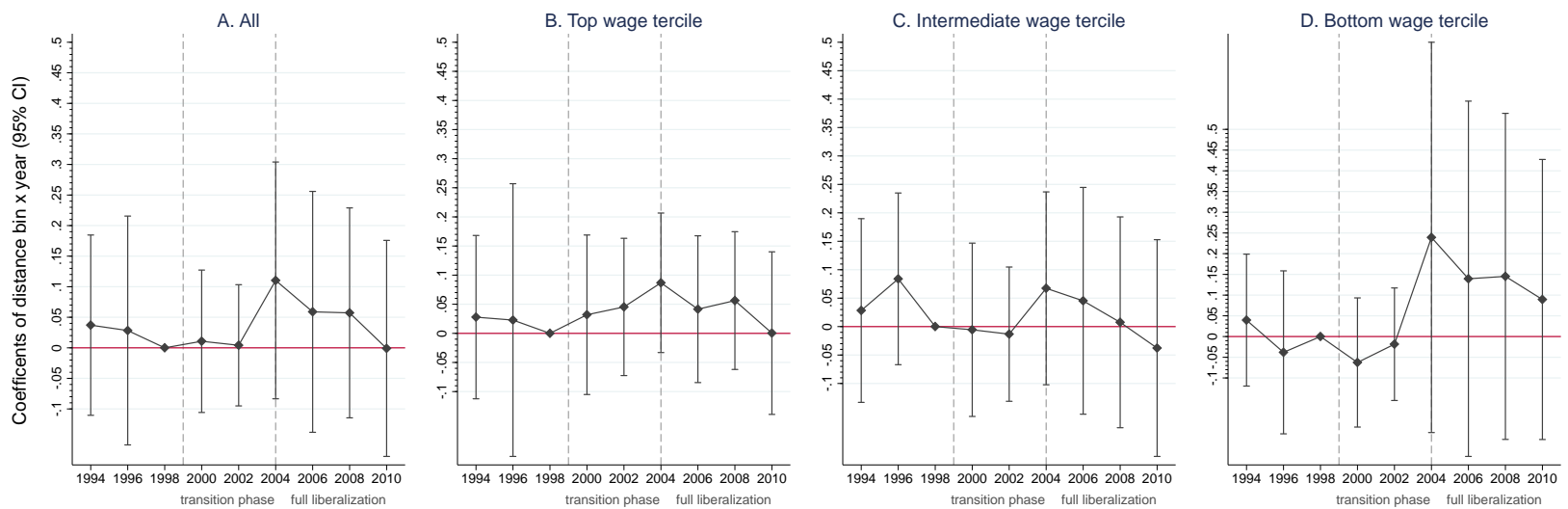

III. Occupation groups (10min bin only)
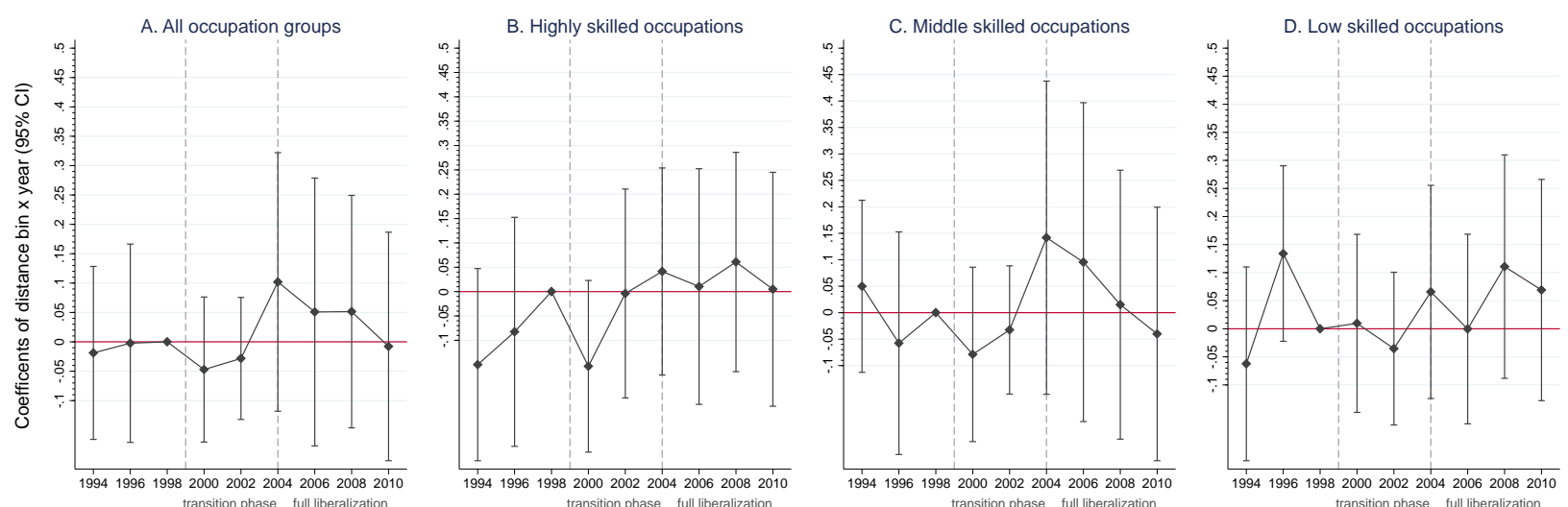

Notes: The figure plots the coefficients (and the $95 \%$ confidence interval for the $0-15 \mathrm{~min}$ or 0-10min distance bin) of a regression based on equation (3) with the log total hours worked of an education group of native workers as dependent variable. Regressions are weighted using the number of native in a cell and include NUTS II trends and the education specific Bartik measure. Standard errors are clustered on the CZ level. The sample includes only municipalities in the border region. In panel II, a skill group is defined as the wage tercile (computed yearly with aggregate employment) to which an individual's wage belongs. In panel III, the each occupation is allocated according to their share of employment by education group. Occupations with more than $30 \%$ of employment with high education are high skilled occupations (Management, R\&D, Evaluation/Consulting/Certification, Education, Logistics/Strategy department, Planing/Design). Occupations with more than 30\% of employment with low education are low skilled occupations (Construction, Transport, Manufacturing/Processing, Restoration/Craft, Cleaning, Hotels/Restaurants, Manicure/Laundry) The remaining occupations are middle skilled occupations (Trading, Accounting/HR, Culture/Entertainment/Information, Machine Operators, Clerks, Medical/Nursing/Social Work, Security, Retail). SESS data. 
Table A6a: Effect of free movement policy on wages and hours worked by natives, robustness check accounting for regional trends and border cities

\begin{tabular}{|c|c|c|c|c|c|c|c|c|}
\hline \multirow[t]{2}{*}{ Dependent variable } & \multicolumn{4}{|c|}{ Mean log hourly wages } & \multicolumn{4}{|c|}{ Log \# hours } \\
\hline & $(1)$ & $(2)$ & $(3)$ & $(4)$ & $(5)$ & $(6)$ & $(7)$ & $(8)$ \\
\hline Transition $_{t} \cdot I\left(\right.$ dist $\left._{m} \leq 10\right)$ & $\begin{array}{c}0.004 \\
(0.010)\end{array}$ & $\begin{array}{c}0.015 \\
(0.009)^{*}\end{array}$ & $\begin{array}{c}0.014 \\
(0.011)\end{array}$ & $\begin{array}{c}0.007 \\
(0.010)\end{array}$ & $\begin{array}{l}-0.026 \\
(0.051)\end{array}$ & $\begin{array}{l}-0.058 \\
(0.066)\end{array}$ & $\begin{array}{c}0.009 \\
(0.045)\end{array}$ & $\begin{array}{l}-0.037 \\
(0.074)\end{array}$ \\
\hline Transition $_{t} \cdot I\left(10<\right.$ dist $\left._{m} \leq 20\right)$ & $\begin{array}{c}0.018 \\
(0.009)^{*}\end{array}$ & $\begin{array}{c}0.012 \\
(0.010)\end{array}$ & $\begin{array}{c}0.012 \\
(0.010)\end{array}$ & & $\begin{array}{c}0.082 \\
(0.062)\end{array}$ & $\begin{array}{c}0.081 \\
(0.061)\end{array}$ & $\begin{array}{c}0.090 \\
(0.062)\end{array}$ & \\
\hline Transition $_{t} \cdot I\left(20<\right.$ dist $\left._{m} \leq 30\right)$ & $\begin{array}{c}0.011 \\
(0.009)\end{array}$ & $\begin{array}{c}0.009 \\
(0.008)\end{array}$ & $\begin{array}{l}-0.003 \\
(0.007)\end{array}$ & & $\begin{array}{c}0.014 \\
(0.051)\end{array}$ & $\begin{array}{c}0.017 \\
(0.052)\end{array}$ & $\begin{array}{c}0.074 \\
(0.063)\end{array}$ & \\
\hline$F R E E_{t} \cdot I\left(\right.$ dist $\left._{m} \leq 10\right)$ & $\begin{array}{l}-0.018 \\
(0.024)\end{array}$ & $\begin{array}{c}0.005 \\
(0.015)\end{array}$ & $\begin{array}{c}0.021 \\
(0.013)\end{array}$ & $\begin{array}{c}0.005 \\
(0.018)\end{array}$ & $\begin{array}{c}0.023 \\
(0.045)\end{array}$ & $\begin{array}{l}-0.046 \\
(0.043)\end{array}$ & $\begin{array}{l}-0.032 \\
(0.042)\end{array}$ & $\begin{array}{c}0.012 \\
(0.045)\end{array}$ \\
\hline$F R E E_{t} \cdot I\left(10<\right.$ dist $\left._{m} \leq 20\right)$ & $\begin{array}{c}0.011 \\
(0.007)\end{array}$ & $\begin{array}{c}0.001 \\
(0.008)\end{array}$ & $\begin{array}{l}-0.001 \\
(0.008)\end{array}$ & & $\begin{array}{l}-0.000 \\
(0.053)\end{array}$ & $\begin{array}{l}-0.002 \\
(0.052)\end{array}$ & $\begin{array}{c}0.016 \\
(0.055)\end{array}$ & \\
\hline$F R E E_{t} \cdot I\left(20<\right.$ dist $\left._{m} \leq 30\right)$ & $\begin{array}{c}0.006 \\
(0.008)\end{array}$ & $\begin{array}{c}0.003 \\
(0.006)\end{array}$ & $\begin{array}{l}-0.005 \\
(0.009)\end{array}$ & & $\begin{array}{c}0.031 \\
(0.040)\end{array}$ & $\begin{array}{c}0.037 \\
(0.040)\end{array}$ & $\begin{array}{c}0.081 \\
(0.052)\end{array}$ & \\
\hline R-squared & 0.775 & 0.785 & 0.718 & 0.738 & 0.975 & 0.976 & 0.948 & 0.977 \\
\hline Observations & 11727 & 11727 & 11700 & 5348 & 11734 & 11734 & 11707 & 5355 \\
\hline $\begin{array}{l}\text { Without border cities } \\
\text { Matched Sample }\end{array}$ & & & $\sqrt{ }$ & $\sqrt{ }$ & & & $\sqrt{ }$ & $\sqrt{ }$ \\
\hline $\begin{array}{l}\text { Year/Area fixed effects } \\
\text { Bartik } \\
\text { Regional trends } \\
\end{array}$ & $\begin{array}{c}\sqrt{ } \\
\sqrt{ } \\
\text { NutsII } \\
\end{array}$ & $\begin{array}{c}\sqrt{ } \\
\sqrt{ } \\
\text { Canton } \\
\end{array}$ & $\begin{array}{l}\sqrt{ } \\
\sqrt{ }\end{array}$ & $\begin{array}{c}\sqrt{ } \\
\sqrt{ } \\
\text { NutsII } \\
\end{array}$ & $\begin{array}{c}\sqrt{ } \\
\sqrt{ } \\
\text { NutsII } \\
\end{array}$ & $\begin{array}{c}\sqrt{ } \\
\sqrt{ } \\
\text { Canton } \\
\end{array}$ & $\begin{array}{l}\sqrt{ } \\
\sqrt{ }\end{array}$ & $\begin{array}{c}\sqrt{ } \\
\sqrt{ } \\
\text { NutsII } \\
\end{array}$ \\
\hline Clustering of Stand. errors & Mun. & $\mathrm{CZ}$ & $\mathrm{CZ}$ & $\mathrm{CZ}$ & Mun & $\mathrm{CZ}$ & $\mathrm{CZ}$ & $\mathrm{CZ}$ \\
\hline
\end{tabular}

Notes: ${ }^{* * *},{ }^{* *},{ }^{*}$, denote statistical significance at the $1 \%, 5 \%$ and $10 \%$ level, respectively. Robust standard errors, clustered by commuting zone, are given in parentheses. Transition $t$ is one for the period between 2000 and 2003 , whereas FRE $E_{t}$ is one from year 2004 onward. (dist $\left.t_{m} \leq x\right)$ and $\left(y<d i s t_{m} \leq z\right)$ indicate whether a municipality is located less than $x$ travel minutes or between $y$ and $z$ travel minutes from the next border crossing, respectively. Regressions are weighted using the total number of natives in a cell. SESS data. 
Table A6b: Effect of free movement policy on wages and hours worked by natives in education groups, robustness check accounting for regional trends and border cities

\begin{tabular}{|c|c|c|c|c|c|c|c|c|}
\hline \multirow[t]{2}{*}{ Dependent variable } & \multicolumn{4}{|c|}{ Mean log hourly wages } & \multicolumn{4}{|c|}{ Log \# hours } \\
\hline & (1) & $(2)$ & $(3)$ & (4) & $(5)$ & (6) & (7) & $(8)$ \\
\hline \multicolumn{9}{|c|}{ A. Highly educated } \\
\hline Transition $_{t} \cdot I\left(\right.$ dist $\left._{m} \leq 10\right)$ & $\begin{array}{c}0.025 \\
(0.012)^{* *}\end{array}$ & $\begin{array}{c}0.018 \\
(0.011)\end{array}$ & $\begin{array}{c}0.030 \\
(0.013)^{* *}\end{array}$ & $\begin{array}{c}0.021 \\
(0.011)^{*}\end{array}$ & $\begin{array}{c}0.090 \\
(0.074)\end{array}$ & $\begin{array}{c}0.071 \\
(0.086)\end{array}$ & $\begin{array}{c}0.112 \\
(0.081)\end{array}$ & $\begin{array}{l}-0.004 \\
(0.105)\end{array}$ \\
\hline Transition $_{t} \cdot I\left(10<\right.$ dist $\left._{m} \leq 20\right)$ & $\begin{array}{c}0.019 \\
(0.013)\end{array}$ & $\begin{array}{c}0.016 \\
(0.014)\end{array}$ & $\begin{array}{c}0.012 \\
(0.013)\end{array}$ & & $\begin{array}{c}0.194 \\
(0.088)^{* *}\end{array}$ & $\begin{array}{c}0.188 \\
(0.089)^{* *}\end{array}$ & $\begin{array}{c}0.182 \\
(0.089)^{* *}\end{array}$ & \\
\hline Transition $_{t} \cdot I\left(20<\right.$ dist $\left._{m} \leq 30\right)$ & $\begin{array}{c}0.012 \\
(0.015)\end{array}$ & $\begin{array}{c}0.013 \\
(0.014)\end{array}$ & $\begin{array}{l}-0.015 \\
(0.016)\end{array}$ & & $\begin{array}{c}0.161 \\
(0.052)^{* * *}\end{array}$ & $\begin{array}{c}0.168 \\
(0.051)^{* * *}\end{array}$ & $\begin{array}{c}0.186 \\
(0.068)^{* * *}\end{array}$ & \\
\hline$F R E E_{t} \cdot I\left(\right.$ dist $\left._{m} \leq 10\right)$ & $\begin{array}{c}0.044 \\
(0.013)^{* * *}\end{array}$ & $\begin{array}{c}0.027 \\
(0.015)^{*}\end{array}$ & $\begin{array}{c}0.045 \\
(0.023)^{*}\end{array}$ & $\begin{array}{c}0.028 \\
(0.013)^{* *}\end{array}$ & $\begin{array}{c}0.093 \\
(0.056)^{*}\end{array}$ & $\begin{array}{c}0.051 \\
(0.070)\end{array}$ & $\begin{array}{c}0.068 \\
(0.073)\end{array}$ & $\begin{array}{c}0.057 \\
(0.079)\end{array}$ \\
\hline$F R E E_{t} \cdot I\left(10<\right.$ dist $\left._{m} \leq 20\right)$ & $\begin{array}{c}0.038 \\
(0.013)^{* * *}\end{array}$ & $\begin{array}{c}0.030 \\
(0.016)^{*}\end{array}$ & $\begin{array}{c}0.021 \\
(0.011)^{*}\end{array}$ & & $\begin{array}{c}0.117 \\
(0.100)\end{array}$ & $\begin{array}{c}0.102 \\
(0.109)\end{array}$ & $\begin{array}{c}0.091 \\
(0.104)\end{array}$ & \\
\hline$F R E E_{t} \cdot I\left(20<\right.$ dist $\left._{m} \leq 30\right)$ & $\begin{array}{c}0.016 \\
(0.013)\end{array}$ & $\begin{array}{c}0.020 \\
(0.013)\end{array}$ & $\begin{array}{l}-0.003 \\
(0.013)\end{array}$ & & $\begin{array}{c}0.178 \\
(0.055)^{* * *}\end{array}$ & $\begin{array}{c}0.192 \\
(0.050)^{* * *}\end{array}$ & $\begin{array}{c}0.193 \\
(0.072)^{* * *}\end{array}$ & \\
\hline Observations & 8778 & 8778 & 8751 & 4232 & 8810 & 8810 & 8783 & 4252 \\
\hline \multicolumn{9}{|c|}{ B. Middle educated } \\
\hline Transition $_{t} \cdot I\left(\right.$ dist $\left._{m} \leq 10\right)$ & $\begin{array}{l}-0.005 \\
(0.008)\end{array}$ & $\begin{array}{c}0.011 \\
(0.010)\end{array}$ & $\begin{array}{c}0.007 \\
(0.010)\end{array}$ & $\begin{array}{c}0.005 \\
(0.009)\end{array}$ & $\begin{array}{l}-0.079 \\
(0.048)\end{array}$ & $\begin{array}{l}-0.098 \\
(0.059)\end{array}$ & $\begin{array}{l}-0.043 \\
(0.044)\end{array}$ & $\begin{array}{l}-0.051 \\
(0.066)\end{array}$ \\
\hline Transition $_{t} \cdot I\left(10<\right.$ dist $\left._{m} \leq 20\right)$ & $\begin{array}{c}0.007 \\
(0.007)\end{array}$ & $\begin{array}{c}0.003 \\
(0.008)\end{array}$ & $\begin{array}{c}0.002 \\
(0.008)\end{array}$ & & $\begin{array}{c}0.024 \\
(0.056)\end{array}$ & $\begin{array}{c}0.022 \\
(0.056)\end{array}$ & $\begin{array}{c}0.039 \\
(0.056)\end{array}$ & \\
\hline Transition $_{t} \cdot I\left(20<\right.$ dist $\left._{m} \leq 30\right)$ & $\begin{array}{l}-0.006 \\
(0.007)\end{array}$ & $\begin{array}{l}-0.009 \\
(0.007)\end{array}$ & $\begin{array}{l}-0.015 \\
(0.010)\end{array}$ & & $\begin{array}{l}-0.028 \\
(0.056)\end{array}$ & $\begin{array}{l}-0.027 \\
(0.055)\end{array}$ & $\begin{array}{l}0.045 \\
(0.067)\end{array}$ & \\
\hline$F R E E_{t} \cdot I\left(\right.$ dist $\left._{m} \leq 10\right)$ & $\begin{array}{l}-0.027 \\
(0.023)\end{array}$ & $\begin{array}{c}0.006 \\
(0.015)\end{array}$ & $\begin{array}{c}0.014 \\
(0.011)\end{array}$ & $\begin{array}{c}0.003 \\
(0.017)\end{array}$ & $\begin{array}{l}-0.042 \\
(0.043)\end{array}$ & $\begin{array}{c}-0.084 \\
(0.043)^{*}\end{array}$ & $\begin{array}{c}-0.084 \\
(0.037)^{* *}\end{array}$ & $\begin{array}{l}-0.007 \\
(0.042)\end{array}$ \\
\hline$F R E E_{t} \cdot I\left(10<\right.$ dist $\left._{m} \leq 20\right)$ & $\begin{array}{c}0.001 \\
(0.008)\end{array}$ & $\begin{array}{l}-0.007 \\
(0.009)\end{array}$ & $\begin{array}{l}-0.008 \\
(0.008)\end{array}$ & & $\begin{array}{l}-0.042 \\
(0.050)\end{array}$ & $\begin{array}{l}-0.047 \\
(0.049)\end{array}$ & $\begin{array}{l}-0.013 \\
(0.055)\end{array}$ & \\
\hline$F R E E_{t} \cdot I\left(20<\right.$ dist $\left._{m} \leq 30\right)$ & $\begin{array}{l}-0.007 \\
(0.007)\end{array}$ & $\begin{array}{l}-0.010 \\
(0.006)^{*}\end{array}$ & $\begin{array}{l}-0.014 \\
(0.010)\end{array}$ & & $\begin{array}{l}-0.024 \\
(0.047)\end{array}$ & $\begin{array}{l}-0.020 \\
(0.049)\end{array}$ & $\begin{array}{c}0.053 \\
(0.050)\end{array}$ & \\
\hline Observations & 11282 & 11282 & 11255 & 5195 & 11287 & 11287 & 11260 & 5201 \\
\hline \multicolumn{9}{|c|}{ C. Low educated } \\
\hline Transition $_{t} \cdot I\left(\right.$ dist $\left._{m} \leq 10\right)$ & $\begin{array}{l}-0.015 \\
(0.016)\end{array}$ & $\begin{array}{l}-0.006 \\
(0.018)\end{array}$ & $\begin{array}{c}0.003 \\
(0.015)\end{array}$ & $\begin{array}{l}-0.003 \\
(0.015)\end{array}$ & $\begin{array}{c}0.051 \\
(0.074)\end{array}$ & $\begin{array}{l}-0.017 \\
(0.112)\end{array}$ & $\begin{array}{c}0.074 \\
(0.066)\end{array}$ & $\begin{array}{l}-0.019 \\
(0.110)\end{array}$ \\
\hline Transition $_{t} \cdot I\left(10<\right.$ dist $\left._{m} \leq 20\right)$ & $\begin{array}{c}0.022 \\
(0.026)\end{array}$ & $\begin{array}{c}0.020 \\
(0.028)\end{array}$ & $\begin{array}{c}0.018 \\
(0.027)\end{array}$ & & $\begin{array}{c}0.169 \\
(0.117)\end{array}$ & $\begin{array}{c}0.189 \\
(0.104)^{*}\end{array}$ & $\begin{array}{c}0.183 \\
(0.107)^{*}\end{array}$ & \\
\hline Transition $_{t} \cdot I\left(20<\right.$ dist $\left._{m} \leq 30\right)$ & $\begin{array}{c}0.010 \\
(0.016)\end{array}$ & $\begin{array}{c}0.009 \\
(0.018)\end{array}$ & $\begin{array}{c}0.003 \\
(0.019)\end{array}$ & & $\begin{array}{c}0.017 \\
(0.093)\end{array}$ & $\begin{array}{c}0.021 \\
(0.092)\end{array}$ & $\begin{array}{c}0.079 \\
(0.097)\end{array}$ & \\
\hline$F R E E_{t} \cdot I\left(\right.$ dist $\left._{m} \leq 10\right)$ & $\begin{array}{c}-0.038 \\
(0.019)^{*}\end{array}$ & $\begin{array}{l}-0.017 \\
(0.018)\end{array}$ & $\begin{array}{c}0.000 \\
(0.013)\end{array}$ & $\begin{array}{c}0.006 \\
(0.018)\end{array}$ & $\begin{array}{c}0.257 \\
(0.139)^{*}\end{array}$ & $\begin{array}{c}0.088 \\
(0.086)\end{array}$ & $\begin{array}{c}0.030 \\
(0.055)\end{array}$ & $\begin{array}{c}0.109 \\
(0.100)\end{array}$ \\
\hline$F R E E_{t} \cdot I\left(10<\right.$ dist $\left._{m} \leq 20\right)$ & $\begin{array}{l}-0.011 \\
(0.012)\end{array}$ & $\begin{array}{l}-0.013 \\
(0.011)\end{array}$ & $\begin{array}{l}-0.015 \\
(0.011)\end{array}$ & & $\begin{array}{c}0.068 \\
(0.074)\end{array}$ & $\begin{array}{c}0.099 \\
(0.064)\end{array}$ & $\begin{array}{c}0.085 \\
(0.048)^{*}\end{array}$ & \\
\hline$F R E E_{t} \cdot I\left(20<\right.$ dist $\left._{m} \leq 30\right)$ & $\begin{array}{l}-0.023 \\
(0.014)\end{array}$ & $\begin{array}{l}-0.026 \\
(0.016)\end{array}$ & $\begin{array}{l}-0.013 \\
(0.011)\end{array}$ & & $\begin{array}{c}0.034 \\
(0.060)\end{array}$ & $\begin{array}{c}0.041 \\
(0.065)\end{array}$ & $\begin{array}{c}0.060 \\
(0.072)\end{array}$ & \\
\hline Observations & 9398 & 9398 & 9371 & 4524 & 9398 & 9398 & 9371 & 4524 \\
\hline $\begin{array}{l}\text { Without border cities } \\
\text { Matched Sample }\end{array}$ & & & $\sqrt{ }$ & $\sqrt{ }$ & & & $\sqrt{ }$ & $\sqrt{ }$ \\
\hline Year/Area fixed effects & $\sqrt{ }$ & $\sqrt{ }$ & $\sqrt{ }$ & $\sqrt{ }$ & $\sqrt{ }$ & $\sqrt{ }$ & $\sqrt{ }$ & $\sqrt{ }$ \\
\hline $\begin{array}{l}\text { Bartik } \\
\text { Regional trends }\end{array}$ & $\begin{array}{c}\sqrt{ } \\
\text { NutsII }\end{array}$ & $\begin{array}{l}\sqrt{ } \\
\text { Canton }\end{array}$ & $\sqrt{ }$ & $\begin{array}{c}\sqrt{ } \\
\text { NutsII }\end{array}$ & $\begin{array}{c}\sqrt{ } \\
\text { NutsII }\end{array}$ & $\begin{array}{c}\sqrt{ } \\
\text { Canton }\end{array}$ & $\sqrt{ }$ & $\underset{V}{\sqrt{ }}$ \\
\hline Clustering of Stand. errors & Mun. & $\mathrm{CZ}$ & $\mathrm{CZ}$ & $\mathrm{CZ}$ & Mun & $\mathrm{CZ}$ & $\mathrm{CZ}$ & $\mathrm{CZ}$ \\
\hline
\end{tabular}

Notes: ${ }^{* * *},{ }^{* *},{ }^{*}$, denote statistical significance at the $1 \%, 5 \%$ and $10 \%$ level, respectively. Robust standard errors, clustered by commuting zone, are given in parentheses. Transition $t$ is one for the period between 2000 and 2003 , whereas FRE $E_{t}$ is one from year 2004 onward. (dist $\left.t_{m} \leq x\right)$ and $\left(y<d i s t_{m} \leq z\right)$ indicate whether a municipality is located less than $x$ travel minutes or between $y$ and $z$ travel minutes from the next border crossing, respectively. Regressions are weighted using the total number of natives in a cell. SESS data. 
Table A7: Effect of free movement policy on inflow and outflow of local employment by natives

\begin{tabular}{|c|c|c|c|c|c|}
\hline \multirow{3}{*}{ Dependent Variable } & \multirow{3}{*}{$\frac{\text { Netflow }}{(1)}$} & \multicolumn{2}{|c|}{ Share inflow from } & \multicolumn{2}{|c|}{ Share outflow to } \\
\hline & & $B R \leq 30$ & $B R>30$ & $B R \leq 30$ & $B R>30$ \\
\hline & & $(2)$ & $(3)$ & $(4)$ & $(5)$ \\
\hline \multicolumn{6}{|c|}{ A. All education groups } \\
\hline Transition $_{t} \cdot I\left(\right.$ dist $\left._{m} \leq 10\right)$ & $\begin{array}{l}-0.016 \\
(0.020)\end{array}$ & $\begin{array}{c}0.015 \\
(0.007)^{* *}\end{array}$ & $\begin{array}{c}0.004 \\
(0.007)\end{array}$ & $\begin{array}{c}0.012 \\
(0.011)\end{array}$ & $\begin{array}{l}0.007 \\
(0.007)\end{array}$ \\
\hline Transition $_{t} \cdot I\left(10<\right.$ dist $\left._{m} \leq 20\right)$ & $\begin{array}{l}-0.038 \\
(0.025)\end{array}$ & $\begin{array}{c}0.003 \\
(0.015)\end{array}$ & $\begin{array}{l}-0.000 \\
(0.009)\end{array}$ & $\begin{array}{c}0.012 \\
(0.010)\end{array}$ & $\begin{array}{l}-0.002 \\
(0.007)\end{array}$ \\
\hline Transition $_{t} \cdot I\left(20<\right.$ dist $\left._{m} \leq 30\right)$ & $\begin{array}{l}-0.033 \\
(0.022)\end{array}$ & $\begin{array}{l}-0.009 \\
(0.008)\end{array}$ & $\begin{array}{l}-0.000 \\
(0.008)\end{array}$ & $\begin{array}{l}-0.008 \\
(0.014)\end{array}$ & $\begin{array}{l}0.006 \\
(0.007)\end{array}$ \\
\hline$F R E E_{t} \cdot I\left(\right.$ dist $\left._{m} \leq 10\right)$ & $\begin{array}{l}-0.019 \\
(0.014)\end{array}$ & $\begin{array}{c}0.001 \\
(0.007)\end{array}$ & $\begin{array}{c}0.004 \\
(0.006)\end{array}$ & $\begin{array}{c}0.010 \\
(0.012)\end{array}$ & $\begin{array}{l}0.007 \\
(0.005)\end{array}$ \\
\hline$F R E E_{t} \cdot I\left(10<\right.$ dist $\left._{m} \leq 20\right)$ & $\begin{array}{l}-0.019 \\
(0.020)\end{array}$ & $\begin{array}{c}0.001 \\
(0.012)\end{array}$ & $\begin{array}{l}-0.003 \\
(0.007)\end{array}$ & $\begin{array}{c}0.009 \\
(0.011)\end{array}$ & $\begin{array}{l}0.006 \\
(0.007)\end{array}$ \\
\hline$F R E E_{t} \cdot I\left(20<\right.$ dist $\left._{m} \leq 30\right)$ & $\begin{array}{l}-0.017 \\
(0.020)\end{array}$ & $\begin{array}{l}-0.011 \\
(0.009)\end{array}$ & $\begin{array}{c}0.003 \\
(0.009)\end{array}$ & $\begin{array}{l}-0.007 \\
(0.012)\end{array}$ & $\begin{array}{c}0.004 \\
(0.007)\end{array}$ \\
\hline \multicolumn{6}{|c|}{ B. Highly educated } \\
\hline Transition $_{t} \cdot I\left(\right.$ dist $\left._{m} \leq 10\right)$ & $\begin{array}{l}-0.044 \\
(0.042)\end{array}$ & $\begin{array}{l}-0.005 \\
(0.013)\end{array}$ & $\begin{array}{c}0.014 \\
(0.014)\end{array}$ & $\begin{array}{c}0.031 \\
(0.019)\end{array}$ & $\begin{array}{c}0.022 \\
(0.016)\end{array}$ \\
\hline Transition $_{t} \cdot I\left(10<\right.$ dist $\left._{m} \leq 20\right)$ & $\begin{array}{l}-0.048 \\
(0.037)\end{array}$ & $\begin{array}{c}0.003 \\
(0.020)\end{array}$ & $\begin{array}{c}0.022 \\
(0.027)\end{array}$ & $\begin{array}{c}0.001 \\
(0.033)\end{array}$ & $\begin{array}{l}-0.010 \\
(0.016)\end{array}$ \\
\hline Transition $_{t} \cdot I\left(20<\right.$ dist $\left._{m} \leq 30\right)$ & $\begin{array}{c}-0.053 \\
(0.030)^{*}\end{array}$ & $\begin{array}{l}-0.015 \\
(0.015)\end{array}$ & $\begin{array}{l}-0.006 \\
(0.017)\end{array}$ & $\begin{array}{l}-0.006 \\
(0.013)\end{array}$ & $\begin{array}{c}0.017 \\
(0.013)\end{array}$ \\
\hline$F R E E_{t} \cdot I\left(\right.$ dist $\left._{m} \leq 10\right)$ & $\begin{array}{l}-0.036 \\
(0.028)\end{array}$ & $\begin{array}{l}-0.017 \\
(0.016)\end{array}$ & $\begin{array}{c}0.003 \\
(0.013)\end{array}$ & $\begin{array}{c}0.012 \\
(0.018)\end{array}$ & $\begin{array}{c}0.008 \\
(0.010)\end{array}$ \\
\hline$F R E E_{t} \cdot I\left(10<\right.$ dist $\left._{m} \leq 20\right)$ & $\begin{array}{l}-0.028 \\
(0.035)\end{array}$ & $\begin{array}{l}-0.011 \\
(0.024)\end{array}$ & $\begin{array}{l}-0.018 \\
(0.017)\end{array}$ & $\begin{array}{l}-0.013 \\
(0.023)\end{array}$ & $\begin{array}{l}-0.024 \\
(0.015)\end{array}$ \\
\hline$F R E E_{t} \cdot I\left(20<\right.$ dist $\left._{m} \leq 30\right)$ & $\begin{array}{l}-0.002 \\
(0.029)\end{array}$ & $\begin{array}{l}-0.020 \\
(0.018)\end{array}$ & $\begin{array}{l}-0.009 \\
(0.020)\end{array}$ & $\begin{array}{l}-0.028 \\
(0.017)\end{array}$ & $\begin{array}{l}0.007 \\
(0.014)\end{array}$ \\
\hline \multicolumn{6}{|c|}{ C. Middle educated } \\
\hline Transition $_{t} \cdot I\left(\right.$ dist $\left._{m} \leq 10\right)$ & $\begin{array}{l}-0.016 \\
(0.027)\end{array}$ & $\begin{array}{c}0.017 \\
(0.008)^{* *}\end{array}$ & $\begin{array}{c}0.000 \\
(0.007)\end{array}$ & $\begin{array}{l}-0.001 \\
(0.013)\end{array}$ & $\begin{array}{c}0.005 \\
(0.009)\end{array}$ \\
\hline Transition $_{t} \cdot I\left(10<\right.$ dist $\left._{m} \leq 20\right)$ & $\begin{array}{l}-0.032 \\
(0.030)\end{array}$ & $\begin{array}{c}0.014 \\
(0.017)\end{array}$ & $\begin{array}{l}-0.007 \\
(0.007)\end{array}$ & $\begin{array}{c}0.015 \\
(0.013)\end{array}$ & $\begin{array}{l}0.005 \\
(0.010)\end{array}$ \\
\hline Transition $_{t} \cdot I\left(20<\right.$ dist $\left._{m} \leq 30\right)$ & $\begin{array}{l}-0.045 \\
(0.034)\end{array}$ & $\begin{array}{l}-0.016 \\
(0.011)\end{array}$ & $\begin{array}{l}-0.005 \\
(0.007)\end{array}$ & $\begin{array}{l}-0.012 \\
(0.018)\end{array}$ & $\begin{array}{l}0.007 \\
(0.010)\end{array}$ \\
\hline$F R E E_{t} \cdot I\left(\right.$ dist $\left._{m} \leq 10\right)$ & $\begin{array}{l}-0.012 \\
(0.019)\end{array}$ & $\begin{array}{c}0.015 \\
(0.007)^{* *}\end{array}$ & $\begin{array}{c}0.006 \\
(0.007)\end{array}$ & $\begin{array}{c}0.010 \\
(0.012)\end{array}$ & $\begin{array}{c}0.013 \\
(0.007)^{*}\end{array}$ \\
\hline$F R E E_{t} \cdot I\left(10<\right.$ dist $\left._{m} \leq 20\right)$ & $\begin{array}{c}-0.044 \\
(0.022)^{*}\end{array}$ & $\begin{array}{c}0.006 \\
(0.014)\end{array}$ & $\begin{array}{c}0.001 \\
(0.009)\end{array}$ & $\begin{array}{c}0.020 \\
(0.012)\end{array}$ & $\begin{array}{c}0.024 \\
(0.008)^{* * *}\end{array}$ \\
\hline$F R E E_{t} \cdot I\left(20<\right.$ dist $\left._{m} \leq 30\right)$ & $\begin{array}{c}-0.043 \\
(0.026)^{*}\end{array}$ & $\begin{array}{l}-0.017 \\
(0.009)^{*}\end{array}$ & $\begin{array}{l}-0.001 \\
(0.008)\end{array}$ & $\begin{array}{l}-0.001 \\
(0.013)\end{array}$ & $\begin{array}{c}0.014 \\
(0.007)^{*}\end{array}$ \\
\hline \multicolumn{6}{|c|}{ D. Low educated } \\
\hline Transition $_{t} \cdot I\left(\right.$ dist $\left._{m} \leq 10\right)$ & $\begin{array}{c}0.006 \\
(0.040)\end{array}$ & $\begin{array}{c}0.026 \\
(0.027)\end{array}$ & $\begin{array}{c}0.006 \\
(0.012)\end{array}$ & $\begin{array}{c}0.029 \\
(0.017)^{*}\end{array}$ & $\begin{array}{c}0.012 \\
(0.016)\end{array}$ \\
\hline Transition $_{t} \cdot I\left(10<\right.$ dist $\left._{m} \leq 20\right)$ & $\begin{array}{c}0.023 \\
(0.093)\end{array}$ & $\begin{array}{c}0.048 \\
(0.028)^{*}\end{array}$ & $\begin{array}{c}0.003 \\
(0.012)\end{array}$ & $\begin{array}{l}-0.080 \\
(0.053)\end{array}$ & $\begin{array}{c}0.035 \\
(0.020)^{*}\end{array}$ \\
\hline Transition $_{t} \cdot I\left(20<\right.$ dist $\left._{m} \leq 30\right)$ & $\begin{array}{c}0.024 \\
(0.081)\end{array}$ & $\begin{array}{l}-0.006 \\
(0.020)\end{array}$ & $\begin{array}{c}0.008 \\
(0.019)\end{array}$ & $\begin{array}{l}-0.034 \\
(0.022)\end{array}$ & $\begin{array}{c}0.047 \\
(0.022)^{* *}\end{array}$ \\
\hline$F R E E_{t} \cdot I\left(\right.$ dist $\left._{m} \leq 10\right)$ & $\begin{array}{l}-0.027 \\
(0.042)\end{array}$ & $\begin{array}{c}0.009 \\
(0.022)\end{array}$ & $\begin{array}{l}-0.006 \\
(0.016)\end{array}$ & $\begin{array}{c}0.043 \\
(0.031)\end{array}$ & $\begin{array}{l}-0.030 \\
(0.021)\end{array}$ \\
\hline$F R E E_{t} \cdot I\left(10<\right.$ dist $\left._{m} \leq 20\right)$ & $\begin{array}{c}0.172 \\
(0.076)^{* *}\end{array}$ & $\begin{array}{c}0.151 \\
(0.040)^{* * *}\end{array}$ & $\begin{array}{l}-0.008 \\
(0.013)\end{array}$ & $\begin{array}{l}-0.070 \\
(0.047)\end{array}$ & $\begin{array}{l}-0.019 \\
(0.022)\end{array}$ \\
\hline$F R E E_{t} \cdot I\left(20<\right.$ dist $\left._{m} \leq 30\right)$ & $\begin{array}{c}0.064 \\
(0.069)\end{array}$ & $\begin{array}{c}0.034 \\
(0.023)\end{array}$ & $\begin{array}{c}0.005 \\
(0.020)\end{array}$ & $\begin{array}{l}-0.030 \\
(0.024)\end{array}$ & $\begin{array}{c}0.004 \\
(0.015)\end{array}$ \\
\hline Year/Area fixed effects & $\sqrt{ }$ & $\sqrt{ }$ & $\sqrt{ }$ & $\sqrt{ }$ & $\sqrt{ }$ \\
\hline Bartik & $\sqrt{ }$ & $\sqrt{ }$ & $\sqrt{ }$ & $\sqrt{ }$ & $\sqrt{ }$ \\
\hline Nuts II trend & $\sqrt{ }$ & $\sqrt{ }$ & $\sqrt{ }$ & $\sqrt{ }$ & $\sqrt{ }$ \\
\hline
\end{tabular}

Notes: ${ }^{* * *},{ }^{* *},{ }^{*}$, denote statistical significance at the $1 \%, 5 \%$ and $10 \%$ level, respectively. Robust standard errors, clustered by commuting zone, are given in parentheses. Transition $t$ is one for the period between 2000 and 2003 , whereas FREE $E_{t}$ is one from year 2004 onward. (dist $\left.t_{m} \leq x\right)$ and $\left(y<\right.$ dist $\left._{m} \leq z\right)$ indicate whether a municipality is located less than $x$ travel minutes or between $y$ and $z$ travel minutes from the next border crossing, respectively. Regressions are weighted using the total number of natives in a cell. The netflow is the sum of inflow minus outflows between two consecutive years. The inflows into employment in municipality $m$ is composed of inflows from other municipalities in the border region below 30 minutes driving time or above or from non-employment. The estimates for the latter category are omitted from the table for brevity. Outflows are computed similarly. See Section 6.1 and Online Appendix B for more details. SLFS data 1996-2008. 
Table A8: Effect on share of natives working in public sector Dependent variable: Share natives in public sector

\begin{tabular}{lcc}
\hline \hline & $(1)$ & $(2)$ \\
\hline$F R E E_{t} \cdot I\left(\right.$ dist $\left._{m} \leq 10\right)$ & 0.009 & 0.011 \\
& $(0.003)^{* * *}$ & $(0.004)^{* * *}$ \\
$F R E E_{t} \cdot I\left(10<\right.$ dist $\left._{m} \leq 20\right)$ & 0.009 & 0.010 \\
$F R E E_{t} \cdot I\left(20<\right.$ dist $\left._{m} \leq 30\right)$ & $(0.006)$ & $(0.006)^{*}$ \\
& -0.003 & -0.002 \\
R-squared & $(0.003)$ & $(0.003)$ \\
Observations & 0.894 & 0.901 \\
Including NBR sample & 7989 & 12455 \\
\hline Year/Area fixed effects & & $\sqrt{ }$ \\
Bartik & $\sqrt{ }$ & $\sqrt{ }$ \\
Nuts II trend & $\sqrt{ }$ & $\sqrt{ }$ \\
\hline
\end{tabular}

Notes: ${ }^{* * *},{ }^{* *},{ }^{*}$, denote statistical significance at the $1 \%, 5 \%$ and $10 \%$ level, respectively. Robust standard errors, clustered by commuting zone, are given in parentheses. $F R E E_{t}$ is one from year 2004 onward. (dist $m \leq x)$ and $\left(y<\right.$ dist $\left._{m} \leq z\right)$ indicate whether a municipality is located less than $x$ travel minutes or between $y$ and $z$ travel minutes from the next border crossing, respectively. Regressions are weighted using the total number of natives in a cell. BC data.

Table A9: Effect of the free movement policy on log hourly wages by demographic group of highly educated natives

Dependent variable: Log hours worked by highly-educated natives by demographic

\begin{tabular}{|c|c|c|c|c|c|c|c|}
\hline \multirow[t]{3}{*}{ Demographic Group } & \multirow{3}{*}{$\begin{array}{l}\text { All } \\
(1)\end{array}$} & \multicolumn{2}{|c|}{ Gender } & \multicolumn{2}{|c|}{ Age } & \multicolumn{2}{|c|}{ Tenure } \\
\hline & & male & female & old & young & high & low \\
\hline & & $(2)$ & (3) & (4) & $(5)$ & (6) & (7) \\
\hline$F R E E_{t} \cdot I\left(\right.$ dist $\left._{m} \leq 10\right)$ & $\begin{array}{c}0.057 \\
(0.036)\end{array}$ & $\begin{array}{c}0.087 \\
(0.036)^{* *}\end{array}$ & $\begin{array}{c}-0.038 \\
(0.058)\end{array}$ & $\begin{array}{c}0.082 \\
(0.044)^{*}\end{array}$ & $\begin{array}{c}0.060 \\
(0.051)\end{array}$ & $\begin{array}{c}0.105 \\
(0.046)^{* *}\end{array}$ & $\begin{array}{c}0.062 \\
(0.052)\end{array}$ \\
\hline R-squared & 0.975 & 0.972 & 0.966 & 0.973 & 0.969 & 0.965 & 0.973 \\
\hline Observations & 8810 & 8436 & 6068 & 8048 & 7348 & 7722 & 7613 \\
\hline $\begin{array}{l}\text { Year/Area fixed effects } \\
\text { Bartik } \\
\text { Nuts II trend }\end{array}$ & $\begin{array}{l}\sqrt{ } \\
\sqrt{ } \\
\sqrt{ }\end{array}$ & $\begin{array}{l}\sqrt{ } \\
\sqrt{ } \\
\sqrt{ }\end{array}$ & $\begin{array}{l}\sqrt{ } \\
\sqrt{ } \\
\sqrt{ }\end{array}$ & $\begin{array}{l}\sqrt{ } \\
\sqrt{ } \\
\sqrt{ }\end{array}$ & $\begin{array}{l}\sqrt{ } \\
\sqrt{ } \\
\sqrt{ }\end{array}$ & $\begin{array}{l}\sqrt{ } \\
\sqrt{ } \\
\sqrt{ }\end{array}$ & $\begin{array}{l}\sqrt{ } \\
\sqrt{ } \\
\sqrt{ }\end{array}$ \\
\hline
\end{tabular}

Notes: ${ }^{* * *},{ }^{* *},{ }^{*}$, denote statistical significance at the $1 \%, 5 \%$ and $10 \%$ level, respectively. Robust standard errors, clustered by commuting zone, are given in parentheses. Transition $_{t}$ is one for the period between 2000 and 2003, whereas $F R E E_{t}$ is one from year 2004 onward. $\left(\right.$ dist $\left._{m} \leq x\right)$ and $\left(y<\right.$ dist $\left._{m} \leq z\right)$ indicate whether a municipality is located less than $x$ travel minutes or between $y$ and $z$ travel minutes from the next border crossing, respectively. Regressions are weighted using the total number of natives in a cell. SESS data. 
Table A10: Distribution of cross-border workers across work-places with different majority languages in Switzerland

\begin{tabular}{lcccc}
\hline \hline & \multicolumn{4}{c}{$\begin{array}{l}\text { Share of origin country group working } \\
\text { in municipality with majority language }\end{array}$} \\
\cline { 2 - 5 } & German & French & Italian & Romansh \\
\hline Cross-Border Workers from & & & & \\
France & 0.246 & 0.753 & 0.001 & 0.000 \\
Italy & 0.083 & 0.018 & 0.891 & 0.008 \\
Germany & 0.983 & 0.012 & 0.004 & 0.000 \\
Austria & 0.973 & 0.008 & 0.002 & 0.017 \\
\hline \hline
\end{tabular}

Notes: The origin country shares of the four neighbouring countries were calculated using data on cross-border workers from the Federal Statistical Office in 1998 and 2010 (the official name for this dataset is "Grenzgängerstatistik"). Note that an 'origin country' is the nationality of a worker in the cross-border worker. 


\section{B Data Appendix}

\section{B.1 Measurement of employment transitions}

To calculate transition rates, we use the Swiss Labor Force Survey (SLFS) and exploit its rolling panel structure, i.e. individuals are called back in the SLFS up to 4 consecutive years after their first interview. However, for our purpose only the panel of two consecutive years is of reasonable size. Using information on the labor force status and municipality of work in the previous year of any individual worker, we can decompose total employment of group $G$ in a municipality $m$, $E_{m, t}^{G}$, as follows

$$
E_{m, t}^{G}=S T A Y_{m, t-1, t}^{G}+I N_{m, t-1, t}^{G}
$$

where $S T A Y_{m, t-1, t}^{G}$ is the number of individuals who stayed employed in municipality $m$ between the previous year $t-1$ and this year $t$ and those who moved into employment in municipality $m$ during the same period, $I N_{m, t-1, t}^{G}$. Inflows can be further disaggregated into inflows from other municipalities, $I N_{m, t-1, t}^{G,-m \rightarrow m}$ in the treated border region (below 30 minutes travel time from the border) or from municipalities in the control region (in the border region above 30 minutes from the border). Inflow can also come from non-employment, $I N_{m, t-1, t}^{G, N E \rightarrow m}$. In a similar fashion, we can decompose the current total employment with a forward perspective:

$$
E_{m, t}^{G}=S T A Y_{m, t, t+1}^{G}+O U T_{m, t, t+1}^{G}
$$

where $S T A Y_{m, t, t+1}^{G}$ and $O U T_{m, t, t+1}^{G}$ constitute the individuals staying employed in $m$ or leaving employment in $m$ from this year $t$ to next year $t+1$, respectively. Analogously, outflows can be decomposed into outflows to employment in other areas, $O U T_{m, t, t+1}^{G, m \rightarrow-m}$ (treatment or control regions), and to non-employment, $O U T_{m, t, t+1}^{G, m \rightarrow N E}$.

Lastly, the sum of inflow minus outflow constitute the net change of total employment of a group $G$ in a municipality $m$

$$
N E T_{m, t, t+1}^{G}=I N_{m, t, t+1}^{G}-O U T_{m, t, t+1}^{G}=E_{m, t+1}^{G}-E_{m, t}^{G}
$$

As we only have information on the municipality of work in the years 1996 to 2009 in the SLFS, we can calculate inflow rates from 1997 to 2009 and outflow rates from 1996 to 2008, respectively, by calculating the likelihood of each category in a municipality-year-education group cell, e.g. in the first year the outflow rate is $O U T_{m, 96,97}^{G} / E_{m, 96}$ and the inflow rate is $I N_{m, 96,97}^{G} / E_{m, 97} \cdot{ }^{45}$ The net inflow, in turn, is calculated as $N E T_{m, 96,97}^{G} / \widetilde{E}_{m, 96,97} \equiv I N_{m, 96,97}^{G} / E_{m, 97}-$ $O U T_{m, 96,97}^{G} / E_{m, 96}$.

For consistency in the regression analysis, inflow rates are always deferred one year back and, thus, are used for the same years as the outflow rates in the regression analysis between 1996 and 2008 where each year refers to the flow between the current year and the next year. Cells are weighted using their total employment in a year.

\section{More Details on Reform and the Institutional Framework}

\section{C.1 Bilateral agreements between Switzerland and the EU}

The bilateral agreements I, signed in June 1999 between Switzerland and the EU, included, apart from the free movement policy, six other liberalization agreements (Bundesrat, 1999):

\footnotetext{
${ }^{45}$ In so doing, we use the panel survey weights provided for the OFS for the SLFS data.
} 
- The agreement on technical barriers to trade (or "Mutual Recognition Agreement") aimed at the mutual recognition of conformity tests for a wide range of industrial products. ${ }^{46}$ This implies, that the declaration of conformity from a Swiss test centre is also valid in the EU and vice versa reducing the time and costs for trading goods.

- The agreement on agricultural products facilitates trade of particular agricultural products by reducing customs duties and non-tariff barriers for selected products. ${ }^{47}$

- With the agreement on overland transport, the Swiss government raised the weight limit of heavy goods vehicles gradually to 40 metric tonnes after 2002 and introduced a tax on heavy vehicles, providing incentives for transalpine freight to shift from road to rail. The agreement on civil aviation allowed reciprocal access to aviation markets including landing rights and was fully implemented in 2002 .

- The agreement on public procurement extends the WTO rules and requires larger tenders by municipalities and certain sectors (e.g. telecommunication, rail transport and water and energy) to be subject to compulsory tendering. ${ }^{48}$

- The agreement on scientific and technological cooperation allows Swiss researchers to participate in EU research framework programs.

In an assessment to which degree each of the bilateral agreements facilitated market access for a particular industry, Bühler, Helm and Lechner (2011) expect the manufacturing industries to be most affected and, to a lesser extent, some service industries (particularly vehicle trade and wholesale and commission trade). Based on these classification, Bühler, Helm and Lechner (2011) find that employment growth was 1-2 percentage points larger among affected firms after the implementation of the bilateral agreements in 2002.

Based on an assessment to which degree the entire package of bilateral agreements liberalised access to the EU market for a particular 2-digit industry, Bühler, Helm and Lechner (2011) classify firms into three groups of high, low and non-affected sectors.

A second set of bilateral agreements (II) where signed in October 2004 and approved in a referendum with $55 \%$ favorable votes on June $5,2005 .{ }^{49}$ The most relevant agreement for our study is the Schengen agreement which abolished the control of individuals at the border traveling. Yet, persons can still be controlled at the border and border guards remain at the border as Switzerland does not belong to the EU customs union (or in the event of an initial suspicion of a criminal offence. Schengen became effective on December 12, 2008. ${ }^{50}$

\footnotetext{
${ }^{46}$ Conformity tests certify that a product complies with the local regulation (e.g. for toys) and can be offered on its market. Since 1992, Switzerland has adapted its regulation to those of the EU to large degrees. This agreement covers a wide range of products including machines, printers, medical products, motor vehicles, tractors, measuring instruments, telecommunication devices, and, since March 2008, building materials.

${ }^{47}$ Customs duties were reduced for cheese, fruits and vegetables, horticulture, meat and wine. Non-tariff barriers reductions aimed, inter alia, at wine and spirits, organic agriculture, pest control and crop protection, fodder and seeds. The reduction of customs duties was implemented fully for most goods on June 12002 . For cheese, the reductions were introduced step-wise with a full liberalisation after June 1, 2007.

${ }^{48}$ Public tenders are required only above a certain minimum amount, which is approximately CHF 10 million for buildings, CHF 250'000 for goods and services provided to the Confederation and 380'000 for goods and services provided to municipalities and cantons. This agreement was implemented fully in June 2002.

${ }^{49}$ The bilateral agreements II included agreements on border controls and asylum (Schengen \& Dublin, operational December 12, 2008), the taxation of savings (operational July 1, 2005), fight against fraud (operational April 8, 2009), environmental cooperation (effective April 1, 2006), liberalisation of processed agricultural goods (effective March 30, 2005), film promotion (effective April 1, 2006), pensions (effective May 31, 2005) and cooperation with statistics (effective January 1, 2007).

${ }^{50}$ The Schengen agreement also entails increased control at the external border (e.g. airports), a common visa policy and cooperation between the police and justice system.
} 


\section{C.2 Taxation and Social Benefits of Immigrants in Switzerland}

\section{C.2.1 Resident immigrants}

Taxation Taxation of foreign residents in Switzerland depends on the income level and the residency status. ${ }^{51}$ Foreign residents with a short-term (B or L) permit with an annual gross income below 120'000 CHF are subject to a special tax scheme with 'taxation at the source' (Quellensteuer). ${ }^{52}$ Taxes are subtracted directly from the salary by the employer depending on household characteristics (marital status, number of children), the canton of living and the income level (progressivity). For these individuals, a canton-wide tax rate applies which is the weighted average of municipality tax rates within a canton. Thus, these individuals face no variation in their tax burden within a canton. After staying in Switzerland at least five years of uninterruptedly, short-term permit holders can apply for a permanent residency permit.

Permanent residency holders and short-term permit holders with a gross income above $120^{\prime} 000 \mathrm{CHF}$ are subject to the ordinary taxation scheme. The ordinary taxation scheme consists of three layers with income taxes set at the federal, the cantonal and the municipality level. The federal and cantonal tax schedules determine how progressive taxes are. In turn, the municipal tax rate is defined as the cantonal tax rate times a tax multiplier (Steuerfuss) set by the municipality. Thus, the overall tax liability depends on household characteristics (marital status and children), the income level (progressivity) and the municipality of living.

Social benefits In general, unemployment benefits can be claimed in the country where individuals have been employed last. Individuals without employment are allowed to enter and stay in Switzerland conditional on having a health insurance and having sufficient financial funds. Individuals looking for a job can stay for up to six months conditional on having sufficient financial funds (EDA, 2015). Foreign residents with a short-term permit below one year (L or seasonal workers prior to 2002) are entitled for unemployment benefits during the duration of their permit conditional on having contributed at least for six months. After a transition period of seven years after 2002, short-term permit holder are entitled for benefits like natives conditional on a minimum number of contribution months to which also contributions in other countries are taken into account. For foreign residents with a long-term permit of more than one year past contribution months are taken into account already prior to 2002 (Bundesrat, 1999).

Other benefits, like health, accident, disability insurance, pensions schemes largely depend on the country of employment and the time during which contribution have been payed.

\section{C.2.2 Cross-border workers}

Taxation Cross-border workers are also subject to the special tax scheme with taxation at the source. $^{53}$ The introduction of the free movement of persons policy after June 1, 2002, created a new category of cross-border workers which were allowed to commute back only on a weekly basis (rather than daily before). Yet, individuals in this new category ('Wochenaufenthalter') are similarly taxed as cross-border workers prior to the free movement policy. The actual details of this taxation depend on the canton of work and the country of living due to bilateral agreements of Switzerland with each of the neighbouring countries for the taxation of cross-border workers.

CBWs from Germany are subject to taxation at their place of residency. Cantons are allowed to tax these individuals at the source at a maximum rate of $4.5 \%$ of the gross income. ${ }^{54}$ This tax is accounted for when calculating the tax burden in Germany. If a CBW does not return to her residency on more than 60 working days, she gets fully taxed at the source like resident immigrants.

\footnotetext{
${ }^{51}$ This information is largely based on Schmidheiny and Slotwinski (2015).

${ }^{52}$ This threshold is at an gross annual income of 500'000 in the canton Geneva. Individuals who are married to a Swiss resident or a permanent foreign resident are subject to the ordinary tax scheme explained below.

${ }^{53}$ This paragraph is largely based on SSK (2009).

${ }^{54}$ This taxation scheme is subject to a proof of residency (Ansässigkeitsbescheinigung) of the CBW to her employer.
} 
The taxation of CBW from France depends on the canton of work. CBWs working in border cantons (SO, BS, BL, VD, VS, NE and JU) and the canton Bern get only taxed at their residency in France. These cantons receive $4.5 \%$ of all gross incomes payed to CBWs. In the canton of Geneva, CBWs are fully taxed at the source with the canton transferring $3.5 \%$ to the French Department of Ain and Haute-Savoie. All other cantons tax CBWs fully at the source like resident immigrants (see above). ${ }^{55}$

CBW from Italy are subject to the full source taxation in all cantons. In return, the cantons of Grisons, Ticino and Valais transfer $40 \%$ of the gross tax to the Italian border municipalities.

CBW from Austria are subject to the special tax scheme with full source taxation with Switzerland transferring $12.5 \%$ of the tax revenue to Austria.

Social benefits CBW are entitled for unemployment benefits in their country of residence (Bundesrat, 1999). Other benefits, like health, accident, disability insurance, pensions schemes largely depend on the country of employment and the time during which contribution have been payed.

\footnotetext{
${ }^{55}$ To CBWs who get fully taxed at the source French tax authorities grant a tax break amounting to the French tax on the Swiss gross income.
} 